\title{
The Evidentiary Theory of Blackmail: Taking Motives Seriously
}

\author{
Mitchell N. Berman $\dagger$
}

TABLE OF CONTENTS

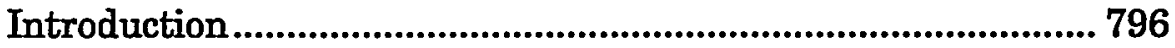

I. Existing Theories: A Survey and Critique............................. 799

A. The Social Consequences of Blackmail.......................... 800

1. Law and Economics: criminalizing inefficient conduct. ................................................................... 800

a) The argument: blackmail produces deadweight loss.

b) Adventitious blackmail: underinclusiveness.

c) Nonadventitious blackmail: the indeterminacy of externalities......................... 808

d) The unbridged gap: why criminalize? ............ 810

2. Richard Epstein: blackmail as the "handmaiden to corruption and deceit."

3. Jeffrie Murphy: blackmail encourages invasions of privacy.................................................................. 817

B. Blackmail as an Inherent Wrong: Of Unconditional Acts and Conditional Threats..................................... 820

1. Feinberg and Gorr: the wrongful act...................... 820

2. Lindgren and Fletcher: the wrongful threat. ........823

3. Katz: the punishment puzzle................................... 826

4. Nozick: blackmail as coercion.................................... 828

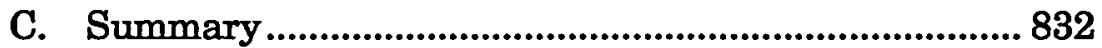

II. A Proposed Solution ................................................................... 833

A. Criteria of Criminalization ............................................ 834

1. General justifying aims. ....................................... 834

$\dagger$ Assistant Professor, The University of Texas School of Law. (C) 1998 Michell N. Berman. I would like to thank Sherman Clark, John Cobau, Richard Friedman, Sam Gross, Don Herzog, Yale Kamisar, Ronald Mann, John Parry, Peter Westen, and James Boyd White for extremely helpful comments on earlier drafts. I am also grateful to the law firm of Jenner \& Block for supporting this project when I was an associate in its Washington, D.C. office. My greatest debt is due my wife, Ingrid Johansen, for her unfailing encouragement, good humor, and sound advice. 
2. Three criteria of criminalization.......................... 835

3. The third criterion: defining terms.......................837 83

B. Criminalizing Blackmail: Of Harm and Bad Motive .. 840

1. A direct approach. .............................................. 840

2. Detour: criminalizing the unconditional disclosure.............................................................. 842

3. Bad motive and the conditional threat................. 844

C. Summary: Resolving the Puzzles .............................. 848

1. The principal puzzle: why the act is legal and the threat illegal. ................................................ 848

2. The secondary puzzle: distinguishing other voluntary transactions......................................... 851

III. Testing the Evidentiary Theory: The Central Case

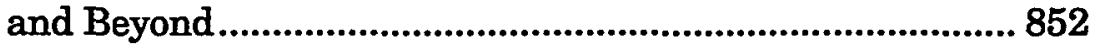

A. A Blackmail Test...................................................... 853

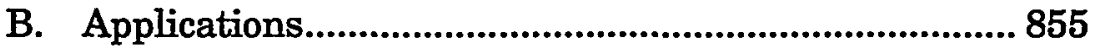

1. "Hard" bargains. ................................................ 855

2. Market price blackmail..................................... 857

3. Crime exposure blackmail. ................................ 860

4. Victim blackmail. ............................................ 862

5. Public interest blackmail.................................. 864

6. Noninformational blackmail............................... 866

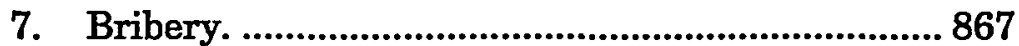

IV. Implications............................................................ 870

A. Motive and Mens Rea in the Criminal Law ................870 870

B. Governmental Motives: Understanding

Unconstitutional Conditions.........................................8.8 873

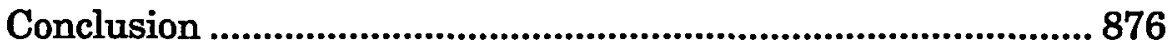

\section{INTRODUCTION}

I am legally free to reveal embarrassing information about you. Generally speaking, I am also free to negotiate payment to refrain from exercising a legal right. But if I combine the two- offering to remain silent for a fee-I am guilty of a felony: blackmail. Why?

The so-called paradox of blackmail ${ }^{1}$ has garnered an extraordinary degree of interdisciplinary scholarly attention. Contribu-

1 Although the reason why the addition of a conditional threat should make a legal difference is obscure, this puzzle is not, as a matter of strict logic, a paradox. See Wendy J. Gordon, Truth and Consequences: The Force of Blackmail's Central Case, $141 \mathrm{U} \mathrm{Pa} \mathrm{L}$ Rev $1741,1742-43$ (1993). Nonetheless, following convention, we need not insist upon the point. 
tors to the debate have included law professors and judges, moral philosophers and economists. Despite many efforts, however, it is an understatement to observe that no consensus has emerged in support of any one or combination of the proffered theories. ${ }^{2}$ Indeed, in his afterword to a symposium devoted to the subject a few years ago, Professor James Lindgren, the most intensely committed contributor to the debate, ventured that the blackmail paradox remains "one of the most elusive intellectual puzzles in all of law."3

This Article proposes a new solution to the puzzle. Specifically, it endeavors both to justify blackmail's criminalization as fully consistent with the central tenets of the criminal law and to explain why, and under what circumstances, blackmail is properly criminalized.

The Article begins, in Section I, by arguing that no current theory adequately unravels the paradox. Each fails to account for significant and substantial aspects of prevailing blackmail law as well as widespread intuitions about what the law should be. Furthermore, Section I seeks to demonstrate that the two predominant approaches to resolving the paradox (in addition to the specific answers thus far proposed) are doomed to failure. Consequentialist theories, which turn upon the particular social consequences of blackmail, and deontological theories, which seek to identify the objective moral difference between the conditional threat to perform an act and the unconditional performance of that same act, will both always prove unable to distinguish blackmail from much behavior that is, and should remain, free from criminal sanction.

Section II develops and defends what I call the evidentiary theory of blackmail. It begins with the proposition that, consistent with consequentialist as well as retributivist conceptions of the justifying aim of the criminal law, society may criminalize conduct that tends both to cause harm and to be undertaken with wrongful motives. On this animating supposition, and because society could (and often does) recognize injury to reputation as le-

2 The fullest elaboration of the puzzle, including critiques of initial efforts to solve it, appears in James Lindgren, Unraveling the Paradox of Blackmail, 84 Colum L Rev 670 (1984). Other especially noteworthy contributions to the literature include Douglas $\mathrm{H}$. Ginsburg and Paul Shechtman, Blackmail: An Economic Analysis of the Law, $141 \mathrm{U}$ Pa L Rev 1849 (1993); Richard A. Posner, Blackmail, Privacy, and Freedom of Contract, $141 \mathrm{U}$ Pa L Rev 1817 (1993); Joel Feinberg, Harmless Wrongdoing 240-58 (Oxford 1988); Richard A. Epstein, Blackmail, Inc., 50 U Chi L Rev 553 (1983); Jeffrie G. Murphy, Blackmail: A Preliminary Inquiry, 63 Monist 156 (1980); and Robert Nozick, Anarchy, State, and Utopia 84-87 (Basic Books 1974).

3 James Lindgren, Blackmail: An Afterword, 141 U Pa L Rev 1975, 1975 (1993). 
gally cognizable harm, a legislature could unproblematically ${ }^{4}$ criminalize all disclosures of embarrassing information so long as we could reasonably believe that most persons who make such disclosures do so with morally unacceptable motives. But the opposite is true: we know that people reveal embarrassing information about others for all types of reasons and, consequently, out of varying moral postures-good, bad, and (arguably) neutral. The diversity of motives for revealing hurtful information about others thus provides a sufficient (if not necessary) explanation for society's refusal to proscribe and punish all such revelations. To be sure, the legislature could try to tailor the offense so as to punish only those persons who disclose embarrassing information with, in Blackstone's term, "vitious will." But in that event the factfinder would confront a hefty challenge: how to determine whether any given defendant acted with the requisite bad motive.

If the defendant were a blackmailer, the task would be much easier. For reasons to be explained, we can usually infer that an individual who discloses embarrassing information only after the person embarrassed by the disclosure fails to pay a requested sum is driven by morally bad motivation to make that disclosure. The act of blackmail thus has evidentiary significance only: it reveals something about the moral character of the actor's motivation that we would be less likely to suspect had he disclosed without first having made the conditional threat. Armed with that (supposed) knowledge, society can punish the blackmailer for the same reason that is sufficient to punish those who engage in unparadoxical, garden variety crimes: because the actor causes (or threatens) harm while acting with morally culpable motives.

Section III simultaneously tests and elaborates the evidentiary theory by analyzing a range of variations within and beyond blackmail's paradigmatic case. This Section justifies criminalizing several types of blackmail that intuition (and, often, existing law) suggests should be criminal, but that one or more prominent theories have been unable to account for. It also explains why several other classes of conduct that share the formal structure of core cases of blackmail should not be criminal. In so doing, this Section invites lawmakers to consider whether it would be feasible to exclude such conduct from the blackmail ban. ${ }^{6}$

4 Unproblematically, that is, as far as criminal theory is concerned. I here put aside considerations strictly exogenous to the criminal law.

- William Blackstone, 4 Commentaries *21.

- This is not to demand a perfect identity between the positive law and the moral import of the evidentiary theory. Law is always somewhat over- and/or underinclusive relative to the dictates of its theoretical justifications. See generally Joseph Story, 1 Commen- 
Section IV suggests some broader lessons of the evidentiary theory. After all, the blackmail paradox is not merely a tantalizing intellectual puzzle. The number and stature of minds it has attracted bespeak a widely held belief that a solution to this single conundrum will bear broad and deep implications. As Lindgren has put it, simply if dramatically: "The struggle to understand blackmail is.a struggle for the soul of the criminal law." This Section offers some thoughts regarding what significance the evidentiary solution to the blackmail puzzle might have for the fundamental questions of criminal theory. Also, in an effort both to buttress the validity of the evidentiary theory in its core application and to demonstrate its utility outside the context of blackmail, I indicate how the analysis developed in Sections II and III might help to resolve yet another of the great mysteries of the law-the doctrine of unconstitutional conditions.

\section{EXISTING THEORIES: A SURVEY AND CRITIQUE}

The blackmail paradox has attracted an impressive array of thinkers from a wide range of disciplines. For purposes of exposition and analysis (and following Lindgren), this Section divides their theories into two broad groups. ${ }^{8}$ Section I.A examines several theories that justify criminalization of blackmail by reference to the supposedly adverse social consequences that could be expected in a regime that tolerated blackmail. Section I.B investigates theories that advocate criminalization on the grounds that blackmail is wrong in and of itself.

Any satisfactory theory must account for both parts of the blackmail puzzle. First, it must explain whether and why blackmail should be made criminal. Second, if it supports criminalization of blackmail, it must explain whether and why unconditional performance of the acts a blackmailer might threaten should remain lawful. Put otherwise, the theory should provide an account of the blackmail threat that both justifies its criminalization ${ }^{9}$ and

taries on Equity Jurisprudence $\$ 7$ (Little, Brown 12th ed 1877); Frederick Schauer, Playing By the Rules 31-34 (Oxford 1991).

7 Lindgren, $141 \mathrm{U} \mathrm{Pa} \mathrm{L} \mathrm{Rev} \mathrm{at} 1975$ (cited in note 3).

- See Lindgren, 84 Colum L Rev at 680 (cited in note 2). This is not quite to label the first category "consequentialists" and the second "deontologists." See, for example, Gordon, $141 \mathrm{U} \mathrm{Pa} \mathrm{L} \mathrm{Rev} \mathrm{at} \mathrm{1741-46} \mathrm{(cited} \mathrm{in} \mathrm{note} \mathrm{1)} \mathrm{(applying} \mathrm{these} \mathrm{labels} \mathrm{to} \mathrm{the} \mathrm{two} \mathrm{categories).}$ One who believes that blackmail is wrong on deontological grounds could approve its criminalization on consequentialist grounds. In other words, it can be important to distinguish the moral bases of claims about the wrongfulness of given conduct from the moral bases of justifications for punishing that conduct. See notes 138-39 and accompanying text.

- Few theories dispute that at least some substantial subset of the present offense of 
distinguishes it, in a manner relevant to that justification, from the act upon which the threat is leveraged. By and large, the theories in the first group passably perform the second task of distinguishing the threat from the act. But they fail to accomplish the first task-showing why blackmail should be criminal. In contrast, several theories in the second group provide seemingly persuasive explanations for blackmail's criminalization, but fail to account adequately for the difference between the threat and the act. No prior theory performs both jobs satisfactorily. ${ }^{10}$

\section{A. The Social Consequences of Blackmail}

This Section considers theories that justify blackmail's criminalization on the grounds that decriminalization would produce undesirable social consequences.

\section{Law and Economics: criminalizing inefficient conduct.}

The principal puzzle of blackmail is this: why is it (and should it be) illegal to threaten to do what it is legal to do absent a threat? ${ }^{11}$ In other words, blackmail is an exception to the general rule of law and morals that one may threaten to exercise one's rights. However, blackmail is also unusual in another respect. Ex post, the successful blackmail transaction looks like a garden variety voluntary exchange: the blackmail "victim" buys

blackmail is properly made criminal. The contested questions, then, concern the reason for its criminalization and the proper contours of the crime. One exception comes from libertarianism. See Murray N. Rothbard, 1 Man, Economy, and State 157 n 49 (Van Nostrand 1962) ("[B]lackmail would not be illegal in the free society. For blackmail is the receipt of money in exchange for the service of not publicizing certain information about the other person. No violence or threat of violence to person or property is involved."). Because Rothbard's conclusion stands or falls upon familiar libertarian premises, however, it need not be addressed here.

${ }^{10}$ This is not to say that a theory is necessarily infirm unless its lessons precisely conform to either present law or common moral intuitions. Rather, the theory must be able to explain outcomes we would deem proper upon considered reflection. For a discussion of this method of "reflective equilibrium," see John Rawls, A Theory of Justice 48-51 (Belknap 1971). Naturally, the "burden of persuasion" will fall most heavily on those theories that depart from the status quo by arguing either that blackmail (or some substantial subset thereof) should be made legal, or that the unconditional performance of some presently legal acts should be made criminal.

"See, for example, Sidney W. DeLong, Blackmailers, Bribe Takers, and the Second Paradox, 141 U Pa L Rev 1663, 1663 (1993) ("The criminalization of blackmail has been considered paradoxical because it would make unlawful a threat to do something the threatener has a legal right to do."); Ginsburg and Shechtman, $141 \mathrm{U}$ Pa L Rev at 1850, 1873 (cited in note 2); Gordon, $141 \mathrm{U} \mathrm{Pa} L \mathrm{Rev}$ at 1742 (cited in note 1); Ronald H. Coase, The 1987 McCorkle Lecture: Blackmail, 74 Va L Rev 655, 667 (1988); Feinberg, Harmless Wrongdoing at 252 (cited in note 2); Glanville L. Williams, Blackmail, 1954 Crim L Rev 79, 162-63. 
the blackmailer's promise not to disclose certain information to which the blackmailer is privy. And, ex ante, the blackmailer's threat to disclose the information unless the deal is consummated looks just like any seller's threat to withhold a good or service unless the potential buyer meets the seller's price. But voluntary transactions are generally favored in the law. A second puzzle of blackmail, then, is this: Why is blackmail, in contrast to other voluntary transactions, illegal? ${ }^{12}$

Because economists are great believers in voluntary transactions, this second puzzle has attracted some of the most distinguished minds in the field of law and economics. Almost all ${ }^{13}$ favor continuing to criminalize blackmail-at least in its paradigmatic case-even while acknowledging that it is a voluntary transaction. Unlike most other voluntary transactions, they argue, blackmail is economically inefficient. This Section presents this economic thesis and then offers three reasons why it is infirm.

a) The argument: blackmail produces deadweight loss. The central insight, associated principally with Judge Douglas Ginsburg and Professor Ronald Coase, is simple: In an ordinary market transaction, goods, services and/or money move in different directions. $A$ gives $\$ \mathrm{x}$ to $B$, and $B$ transfers good y to $A$. Because the parties would not consummate the deal unless each valued her expected end state higher than her initial state, the transaction must make both parties better off. And, all things being equal, it increases net social welfare. In contrast, the objective and the usual result of a blackmail proposal is to redistribute economic resources from the victim, $A$, to the blackmailer, $B$, without oth-

${ }^{12}$ One answer to this puzzle would deny the premise. Under a theory traced to the philosopher Robert Nozick, the blackmail proposal is coercive and, therefore, the consummated blackmail transaction is not a "voluntary" exchange. If the exchange is not voluntary because the blackmailer coerces the victim (and assuming that coercion is a prima facie wrong), the coercion theory belongs to the second category-those that justify criminalization of blackmail as a wrong in itself. See Section I.B.4. In any event, although adherents of the law and economics approach by and large approve of criminalizing blackmail, few if any agree that the deal between blackmailer and victim is "involuntary." See, for example, Posner, $141 \mathrm{U} \mathrm{Pa} \mathrm{L} \mathrm{Rev} \mathrm{at} 1819$ (cited in note 2) ("One alternative to economic analysis in ... the blackmail cases is to play with the meaning of 'voluntary,' for example by confining 'voluntary' acts to those in which severe constraints are absent; but this just adds a layer of uncertainty."); Jennifer Gerarda Brown, Blackmail as Private Justice, $141 \mathrm{U} \mathrm{Pa} \mathrm{L} \operatorname{Rev} 1935,1950 \mathrm{n} 32$ (1993) ("That the blackmailee may be faced with a hard choice between the consequences of disclosure and paying the blackmailer does not necessarily make the blackmail any more coercive than the choice facing many parties to wholly legitimate economic transactions.").

${ }^{13}$ For one exception, see Joseph Isenbergh, Blackmail From A to $C, 141 \mathrm{U} \mathrm{Pa} \mathrm{L} \mathrm{Rev}$ 1905 (1993) (discussed at notes 48-52 and accompanying text). 
erwise changing the status quo ante; $B$ gives nothing of value to $A$. The blackmail transaction is thus a sterile redistributive exchange. Crucially, moreover, it is not a costless one, for the practice consumes two types of resources. The blackmailer invests resources into "digging up the dirt," and both he and his victim incur transaction costs. Blackmail therefore is likely to be inefficient, producing deadweight losses and reducing overall social utility. Hence, Ginsburg, Coase, and others conclude, it should be prohibited. ${ }^{14}$

b) Adventitious blackmail: underinclusiveness. The first problem with the economic thesis is that it is based on a dubious, if not manifestly incorrect, premise. Were blackmail legal and blackmail contracts enforceable, $B$ would be transferring something of value to $A-B$ 's right to perform the act he threatens. Before the transaction is completed, $B$ is legally free to reveal $A$ 's adultery to $A$ 's spouse. By accepting $B$ 's blackmail proposal and tendering payment, however, $A$ buys $B$ 's promise of silence (along, very likely, with such tangible things as photographs and negatives). ${ }^{15}$ If both $B$ and $A$ exchange something of value, then the existence of transaction costs (including resources $B$ invests to procure something valuable to offer $A$ ) seems irrelevant. The economic thesis does not distinguish blackmail from any other economic exchange. Put otherwise, "something does happen in a blackmail bargain: a reframing of property rights between $A$ and B."16

For the economic thesis to make sense, then, this "something" just cannot count. However, it is not immediately obvious precisely why not. ${ }^{17}$ For Ginsburg and Professor Paul Schechtman, the reason is that the above criticism misconceives the proper time of comparison. The key, they argue, is to "view the transaction at its outset," when $B$ first contemplates blackmail and has yet to unearth $\operatorname{dirt}$ on $A$ : "No rational economic planner

"See, for example, Coase, $74 \mathrm{Va} L \mathrm{Lev}$ at 673 (cited in note 11); Ginsburg and Shechtman, 141 U Pa L Rev at 1865 (cited in note 2).

${ }^{15}$ It would be begging the question to object that $B$ 's promise is of no value on the grounds that blackmail is illegal and blackmail contracts are unenforceable. Whether blackmail should be illegal is precisely the question.

${ }^{16}$ Isenbergh, $141 \mathrm{U} \mathrm{Pa} \mathrm{L} \mathrm{Rev} \mathrm{at} 1920$ (cited in note 13).

${ }^{17}$ The reason for not counting it cannot be derived from the supposition that $B$ has no intent to do as he threatens. If the victim has confidence that the blackmailer will not carry out his threat then, as a practical matter, the promise might well be valueless. In that event, however, the victim will call the blackmailer's bluff. If, instead, the victim does consummate a deal with the blackmailer, it can only be because he was not confident that the blackmailer's threat was a bluff, in which case the latter's (legally enforceable) promise not to carry out his threat has value. 
would tolerate the existence of an industry dedicated to digging up dirt, at real resource cost, and then reburying it." ${ }^{18}$ In other words, blackmail appears "nonallocative" if we compare the situation after the blackmail to that before the blackmailer began to ferret for embarrassing information.

But this response hits an intractable difficulty. If the economic thesis must focus on the blackmailer's project before he acquires the potentially damaging information, it cannot justify banning blackmail based on information that he happened upon adventitiously. Professor Mike Hepworth has distinguished four types of blackmail based on the manner in which the damaging information is obtained: in "opportunistic blackmail," the blackmailer innocently stumbles upon information he subsequently realizes will serve as useful blackmail fodder; in "participant blackmail," he was a participant in the conduct about which he later blackmails the victim; in "commercial research blackmail," the blackmailer consciously seeks information in order to blackmail his victim; and in "entrepreneurial blackmail," the blackmailer entices a victim into a compromising situation for the specific purpose of producing the material with which he can blackmail. ${ }^{19}$ Relying on this vocabulary, Lindgren objected years ago (in response to Ginsburg's then unpublished manuscript) that the economic approach is substantially underinclusive because it cannot justify prohibition of either participant or opportunistic blackmail ${ }^{20}$ - likely a large percentage of all blackmail.

Note that Lindgren's objection is not that the potential magnitude of the deadweight loss is significantly smaller in cases of participant and opportunistic blackmail than Ginsburg and Shechtman suppose. It is true that in commercial research and entrepreneurial blackmail, the deadweight loss is measured by the sum of (1) the resources expended to discover the information and (2) the transaction costs, whereas in opportunistic and participant blackmail, transaction costs constitute the entire deadweight loss. Properly understood, though, Lindgren's criticism is far more profound. When the blackmailer does not make an independent effort to dig up information-that is, when the status quo ante cannot be identified as any point prior to when he communicates the blackmail proposal to his victim-then there is no basis for characterizing the completed transaction as nonallocative. The transaction costs, whatever they may be, are facilita-

${ }^{18}$ Ginsburg and Shechtman, $141 \mathrm{U} \mathrm{Pa} \mathrm{L}$ Rev at 1860 (cited in note 2).

${ }^{19}$ Mike Hepworth, Blackmail: Publicity and Secrecy in Everyday Life 73-77 (Routledge 1975).

${ }^{20}$ Lindgren, 84 Colum L Rev at 694-95 (cited in note 2). 
tive, not deadweight-and mirror transaction costs present in ordinary bargaining situations. ${ }^{21}$

Instead of agreeing that their theory cannot explain the criminalization of participant and opportunistic blackmail, Ginsburg and Shechtman argue that the transaction costs still justify prohibiting blackmail even when the information the blackmailer threatens to disclose is adventitiously obtained. In direct response to Lindgren, they claim that

it is of no moment that a particular $B$ may have come by compromising information accidentally. Should $A$ refuse to pay him, $B$ has no reason to begin incurring expenses, such as are necessary to secure publication of the information, except insofar as he is looking to future opportunities for blackmail. The resources he expends in order to publish the information (and presumably to get credit as the source of it) are justified only from his ex ante perspective on the next blackmailing opportunity-regardless of whether $B$ sets out to find it or waits for it again to come knocking at his door. Thus, assuming that the first blackmail opportunity arrives by accident, when $B$ asks for payment to suppress what he knows, he has become an entrepreneur of blackmail; for $B$ then to carry out his threat to reveal the information is an investment decision, not a part of the earlier accident. ${ }^{22}$

This response does not withstand scrutiny. First, and least significantly, insofar as it assumes substantial costs to the blackmailer, the truth is more likely that "[t]he direct cost to a

${ }^{21}$ As Pigou observed, bargaining itself imposes social costs. See A.C. Pigou, The Economics of Welfare 200-03 (Macmillan 4th ed 1932). But because there is no more efficient way of allocating goods and services than by private bargaining, it is hard to know what to do with his observation. There is no way to eliminate bargaining, and the deception that comes with it, without throwing out the baby with the bathwater. See Coase, $74 \mathrm{Va} \mathrm{L} \mathrm{Rev}$ at 671-73 (cited in note 11) (criticizing Pigou). Notably, when it comes to proposing a specific definition of blackmail, Ginsburg and Shechtman appear to overlook the fact that bargaining even in ordinary commercial settings inherently "involves bluff, threats, and, to some degree, deception." Id at 672 . Blackmail, in their view, is a threat to perform a lawful act that would confer no material benefit on the party making the threat. Ginsburg and Shechtman, $141 \mathrm{U} \mathrm{Pa} \mathrm{L} \mathrm{Rev} \mathrm{at} 1865$ (cited in note 2). A moment's reflection reveals that this articulation is overbroad, for it encompasses every "threat" to hold out for a better deal in circumstances where the "threatener's" next best option is inferior to the offer on the table. (For example, it would make an athlete's threat to sit out the season a criminal offense. Would the consequence be that teams could sign most of their draft choices for something close to the minimum wage?) In short, no matter what might be said of their theory, Ginsburg's and Shechtman's definition plainly does not accomplish the task they set for themselves-namely, to distinguish blackmail from the ordinary bargaining that is "actually relied upon in a competitive exchange economy to discipline the market." Id at 1849.

${ }^{2}$ Ginsburg and Shechtman, $141 \mathrm{U} \mathrm{Pa} \mathrm{L} \mathrm{Rev} \mathrm{at} \mathrm{1875-76} \mathrm{(cited} \mathrm{in} \mathrm{note} \mathrm{2).}$ 
blackmailer of actually carrying out his threat is ordinarily trivial; it takes almost no effort to mail a photograph or a document to someone. 323 Second, the claim that $B$ has no reason to incur expenses other than to bolster his reputation as a blackmailer is dubious. If $A$ rejects $B$ 's proposal, $B$ might carry out his threat out of spite. And as Ginsburg and Shechtman themselves acknowledge, there is "no reason in economic theory to dishonor [ $B$ 's] preference for making $A$ suffer."24

Most significantly (and this is a sufficient objection, even if $B$ incurs nontrivial costs to carry out his threat and even if he does so solely in order to strengthen his reputation as a credible threatener), Ginsburg and Schectman are wrong to conclude that "[t]he resources $[B]$ expends ... are justified only from his ex ante perspective on the next blackmailing opportunity."25 Rather, any expenses incurred might well be justified by the blackmailer's anticipation of the next bargaining opportunity. That Ginsburg and Shechtman overlook this basic point is starkly illustrated by their earlier argument that ' $B$ 's only potential gain . . . is in establishing his credibility as someone willing to incur a cost if not obliged. But that is an asset only insofar as $B$ is an entrepreneur of blackmail, i.e., someone who expects to engage in similar future transactions. ${ }^{26}$ Not at all. A reputation as someone willing to forego a benefit or incur costs if not obliged is extraordinarily valuable in the "legitimate" business world. It allows one to secure a disproportionately large share of the potential benefits of exchange. And, when it comes to exploiting that reputation, it should make no difference whether it was forged as an adventitious blackmailer, or as a used car salesman, or as a distributor of fava beans.

It remains to consider one other rejoinder to Lindgren's critique of the law and economic theory-a rejoinder that does not

${ }^{23}$ Steven Shavell, An Economic Analysis of Threats and Their Illegality: Blackmail, Extortion, and Robbery, $141 \mathrm{U}$ Pa L Rev 1877, 1889 (1993). Shavell also notes that "[t]he cost to a blackmailer of carrying out his threat probably inheres mainly in any resulting increase in the risk of his being caught and punished. But the blackmailer can usually reveal his information anonymously, using the mail or the telephone." Id. Shavell's point is even stronger than he seems to realize. The blackmailer's costs of avoiding detection and punishment are not relevant when deciding whether blackmail should be punishable.

${ }^{21}$ Ginsburg and Shechtman, $141 \mathrm{U} \mathrm{Pa} \mathrm{L} \mathrm{Rev} \mathrm{at} 1864$ (cited in note 2) (emphasis added). They proceed to argue, however, that the rational economic planner can ignore $B$ 's welfare interest in acting spitefully on the grounds that "some potential gains are not realizable because they are not as great as the cost entailed in their identification." Id. But if $B$ 's pleasure in harming $A$ counts in the welfare calculus, then a realistic appraisal of the costs incurred by the adventitious blackmailer becomes critical.

${ }^{2 s}$ Id at 1876 (emphasis altered).

${ }^{2}$ Id at 1865 (emphasis added). 
rely on transaction costs. Professor Steven Shavell has agreed that the criminality of participant and opportunistic blackmail "cannot be explained by a need to discourage wasteful efforts to obtain information." Instead, he argues that if adventitious blackmail is not illegal, "potential victims will exercise excessive precautions or reduce their level of innocent, yet embarrassing, activities" to prevent being blackmailed by persons who chance upon damaging information. ${ }^{28}$

This argument, however, will not work. Assume that, were participant and opportunistic blackmail legalized, people would reduce the level of activities that might serve as a basis for blackmail, and would increase precautions against being discovered when they do engage in such activities. Such an assumption is an economic reason for making blackmail illegal only if the costs of these consequences outweigh their social benefits. Surely that is so if we accept Shavell's invitation to consider only innocent activities. However, there is no warrant for adopting such a narrow focus.

As Shavell himself recognizes, three categories of "embarrassing" activities might serve as the basis for blackmail: (1) purely innocent socially harmless acts like "engaging in conventional sexual intercourse with one's spouse, or even taking a shower"; (2) socially harmful but legal acts such as adultery; and (3) criminal acts. ${ }^{29}$ As to the second category-which surely would be as numerous as the first ${ }^{30}$-Shavell concludes that the social value of legalizing blackmail is ambiguous because it is uncertain whether (a) the beneficial effect of reducing socially undesirable activities would outweigh the sum of (b) the blackmailer's "wasteful efforts to obtain information" and (c) the victims' costs of

${ }^{27}$ Shavell, $141 \mathrm{U} \mathrm{Pa}$ L Rev at 1903 (cited in note 23).

${ }^{28} \mathrm{Id}$.

20 Id at 1897-99.

${ }^{30}$ One could object that, because everybody is vulnerable to first category blackmail, its incidence would far exceed that of second category blackmail in a world where blackmail were legalized. I do not think this is the case. In most instances of first category blackmail, the blackmailer must be threatening, not just to reveal information, but to publicize tangible evidence. A blackmailer will not get rich, to take Professor Shavell's example, by threatening to tell a married couple's neighbors and coworkers that the couple engages in conventional sexual intercourse; as Shavell recognizes, the blackmailer must threaten to distribute photos of the act. Id at 1897. But this will not be so easy, for laws (and norms) against privacy invasions would remain operable even under a regime of legal blackmail. Moreover, the potential payoff from such threats would often be too small to encourage the practice. Despite Shavell's examples, the most likely subject of first category blackmail must be innocent, harmless acts that are nonetheless the target of social prejudice. The incidence of first category blackmail would, therefore, diminish in proportion as general social tolerance increases. 
guarding against blackmail. ${ }^{31}$ We will consider shortly whether such an ambivalent conclusion about the overall consequentialist balance warrants much support for a generalized ban on blackmail. ${ }^{32}$ But it is surely not enough to justify criminalizing adventitious blackmail, for it is implausible that the balance would remain ambiguous when no resources have been expended to obtain the information in question. ${ }^{33}$ Consequently, Shavell's "incentivebased" response to Lindgren succeeds at most in justifying continued prohibition of adventitious blackmail of innocent conduct that society has no interest in discouraging.

Therefore, Shavell's contributions notwithstanding, the law and economics approach still cannot justify prohibiting conditional threats to reveal information about socially undesirable ${ }^{34}$ behavior where such information was obtained without cost. ${ }^{35}$

31 Id at 1899.

S2 See notes 38-42 and accompanying text.

* A complete demonstration of this argument would consume more space than the subject warrants, especially since Shavell never expressly develops the contrary claim. In simplified form, the argument assumes that, in a regime where all blackmail is criminal, the discounted cost of detection to a person, $P$, who engages in second category conduct is $x$. Were an exception to the blackmail ban carved out for adventitious blackmail, $P$ would face an additional discounted cost of detection of $y$. Let $n$ equal the costs to $P$ of taking extra precautions to avoid detection, and let $m$ equal the costs to $P$ of foregoing the second category conduct. For any given $P$, allowing adventitious blackmail is costly for society, on Shavell's reasoning, only when (i) $x \leq n<x+y \leq m$. (If $x>n, P$ takes the precautions regardless of whether adventitious blackmail is legalized; if $n \geq x+y, P$ eschews extra precautions even if adventitious blackmail is legalized; if $x+y>m, P$ chooses to forego the activity rather than take additional precautions.) Meanwhile, legalizing adventitious blackmail incurs positive social value if (ii) $x \leq m \leq x+y$. If the values for $y$ are low, events (i) and (ii) are both fairly unlikely. However, assuming that the benefit to society from any one $P$ foregoing the activity at issue is greater than the cost to society from any one $P$ taking extra precautions at cost to him of $n$, event (i) would have to be considerably more common than event (ii) for legalizing adventitious blackmail of second category conduct to be a bad social bargain on Shavell's reasoning. This is not provably false, but seems substantially unlikely.

This argument can be illustrated by considering Shavell's own example of the type of activity that might form the basis for second category blackmail: "the wasteful but not illegal spending of church funds by a minister." Shavell, $141 \mathrm{U} \mathrm{Pa} \mathrm{L} \mathrm{Rev} \mathrm{at} 1898$ (cited in note 23). The beneficial effects of permitting blackmail in such cases is clear-to induce ministers "to use church funds more responsibly." Id at 1899. The principal adverse effect is "the effort expended [by profligate ministers] to . . . avoid blackmail." Id. If, as Shavell asks us to suppose, "the minister can avoid detection if he goes to the trouble of making all purchases with cash instead of his credit card," id, how often would the threat of legalized adventitious blackmail (over and above the threat of detection in a regime that criminalized adventitious blackmail) induce such behavior?

${ }^{3}$ We will bracket the question of whether law and economics justifies the prohibition against blackmail based on threats to reveal socially undesirable and illegal behavior (where the information is obtained with or without expenditure of resources). See Section III.B.3.

${ }^{35}$ Acknowledging in a recent article that the economic responses to Lindgren's challenge have been inadequate, Professor Richard McAdams has proposed a "second-best" 
c) Nonadventitious blackmail: the indeterminacy of externalities. The foregoing analysis does not imply that the economic thesis succeeds in justifying a ban on blackmail based on information that is obtained by the expenditure of resources, for the fact (if true) that a given transaction reduces the aggregate wealth of the actual parties to the exchange does not prove that the transaction reduces the overall wealth of society. As Shavell's effort to resuscitate the economic thesis for prohibiting participant and opportunistic blackmail reflects, economists are as concerned with externalities as they are fond of voluntary exchanges. Accordingly, if the threat and practice of blackmail produced positive externalities (by encouraging socially useful activity or discouraging socially harmful behavior), then a regime that permitted blackmail might be wealth maximizing relative to a regime that prohibited it.

Indeed, Judge Richard Posner has systematically assessed the various types of informational blackmail in an effort to evaluate this very possibility. ${ }^{36}$ Adopting a purportedly exhaustive seven-part classification of acts or conditions that a blackmailer might threaten to reveal, ${ }^{37}$ Posner concludes that in none of the

economic defense of the criminal ban against adventitious blackmail. See Richard $\mathrm{H}$. McAdams, Group Norms, Gossip, and Blackmail, 144 U Pa L Rev 2237, 2266-92 (1996). In McAdams's view, absent social norms, adventitious blackmail produces a suboptimal dissemination of adventitiously discovered information, while a blackmail ban produces a superoptimal dissemination of such information. However, he argues, norms favoring privacy correct the latter inefficiency better than norms favoring disclosure correct the former. Therefore, criminalization of adventitious blackmail is more efficient than legalization.

Though McAdams's argument is intriguing, its consequences are more far-reaching than he concedes and than are acceptable. McAdams claims only to "supplement[ ] the economic theory of blackmail." Id at 2287. See also id at $2267 \mathrm{n} 82$. In fact, his analysis rests on a very different footing. The economic case against blackmail rests on the premise that it is appropriate to criminalize conduct that results in deadweight economic losses. MaAdams recognizes that much adventitious blackmail cannot be justified on that principle. Id at 2287. He also eschews reliance on any administrative difficulties of excepting adventitious blackmail from a general blackmail prohibition. Id at $2270 \mathrm{n} 93$. Therefore, the unstated premise of his argument is that it is a sufficient condition for criminalization that a legal prohibition would likely produce a more "efficient" social distribution of information. It follows that his theory would tolerate an elaborate regime of criminal laws mandating disclosure of certain categories of information and prohibiting concealment of others.

${ }^{36}$ See Posner, 141 U Pa L Rev 1817 (cited in note 2).

${ }^{37}$ Posner's categories are as follows: (1) criminal acts for which the blackmailer's victim has been punished; (2) undetected criminal acts; (3) acts that are wrongful, perhaps tortious, but not criminal; (4) wrongful acts of which the blackmailer (or his principal) was the victim; (5) disreputable or otherwise censurable acts that do not, however, violate any enforced law; (6) involuntary acts or conditions that are a source of potential humiliation; and (7) any of the first six categories, except that the victim did not commit the act for which he is being blackmailed. Id at 1820 . 
cases could we be confident that there would be a countervailing social benefit. On this basis, he agrees with the GinsburgShechtman thesis that blackmail is on average wealth reducing and therefore should be prohibited by the criminal law. ${ }^{38}$

One potential problem with Posner's approach arises from the fact that his taxonomy is not as exhaustive as he suggests. He provides no account of threats to do anything other than disclose information or of demands for something other than pecuniary gain. More troubling is the questionable nature of some of Posner's central conclusions. For example, Posner concedes that the social welfare arguments against his "category two" and "category five" blackmail-threats to reveal that a victim has engaged either in a criminal act for which he was not caught and punished or in disreputable or immoral acts that do not violate any commonly enforced law-are inconclusive. ${ }^{39} \mathrm{He}$ is able to disfavor legalizing such forms of blackmail, therefore, only by privileging "a presumption against the expenditure of scarce political capital on an effort to change laws that are not demonstrably inefficient" over a contrasting "presumption against government intervention in private affairs that is not demonstrably efficient. $\$$

Although Posner's characteristic candor is commendable, his argument is doubly odd. First, it is telling that Posner's analysis yields ambivalent conclusions with regard to these two categories of blackmail. Most people, I venture, would find criminalizing both entirely appropriate. ${ }^{41}$ But it is even more peculiar that Posner is so willing to see both forms of blackmail criminalized notwithstanding the ambivalence of his conclusions-especially given his explicit recognition of the distinction "between an analytical evaluation and a policy recommendation. ${ }^{\$ 42}$ I suspect that most readers would read his article to support the very different conclusion that the economic case against blackmail cannot survive without more rigorous empirical work and predictive model-

Id at 1818.

* Id at 1827, 1835. Posner had visited such issues before. See William M. Landes and Richard A. Posner, The Private Enforcement of Law, 4 J Legal Stud 1, 42-43 (1975) (considering whether a blackmail threat to reveal that the blackmail victim committed a crime might increase social utility-and therefore warrant legalization-by reducing other crimes).

to Posner, $141 \mathrm{U}$ Pa L Rev at 1827 (cited in note 2). See also id at 1835 ("[O]nce again, the argument for allowing blackmail is too speculative to make a strong case for decriminalizing this particular form of extortion.").

${ }^{11}$ As further evidence of Posner's departure from common moral intuition, consider his suggestion that where $A$ is an adulterer, it should be legal for $B$ to threaten to beat him up unless paid if the data revealed "that allowing such threats would reduce breaches of the marital obligation at a cost commensurate with this benefit." Id at 1835.

${ }^{12}$ Id at 1827. 
ling. Unless and until the law and economics scholars can demonstrate more persuasively that blackmail reduces social wealth, it will remain difficult to reconcile their defense of blackmail's criminalization with their methodology's scientific and positivist aspirations.

d) The unbridged gap: why criminalize? Even if nonadventitious blackmail were shown to reduce social wealth, and even if the theory's apparent failure to cover adventitious blackmail could be rectified or excused, reliance on considerations of economic efficiency cannot explain why blackmail is not merely discouraged or even prohibited, but criminalized.

From a retributivist perspective, the premise underlying the economic argument-that economic inefficiency is a sufficient condition for imposing criminal punishment-is anathema. Hence Scott Altman's observation that the economic justification for the criminalization of blackmail must prove unsatisfactory to "all but the most committed consequentialist." ${ }^{343}$ More significantly, though, the premise is false even for committed consequentialists. Because any utilitarian calculus must take into account the pain suffered by the individual whose liberty and happiness is curtailed for the greater good of others, ${ }^{44}$ utilitarianism commands that society adopt the least restrictive means of social control. Similarly, under principles of wealth maximization, ${ }^{45}$ criminalization can be justified only if its incremental deterrent effect compared with other means of deterrence exceeds the greater cost of employing the criminal law. ${ }^{46}$ So on both utilitarian and wealth maximizing grounds, criminalization of blackmail cannot be justified unless the marginal benefit of criminal sanction-relative, say, to making blackmail agreements unenforceable as a matter of contract law (as is presently the case) or making blackmail a tort-outweigh the marginal social cost. ${ }^{47}$

${ }^{13}$ Scott Altman, A Patchwork Theory of Blackmail, 141 U Pa L Rev 1639, 1656 (1993).

* See generally Jeremy Bentham, An Introduction to the Principles of Morals and Legislation 165-74 (Methuen 1970) (originally published in 1789).

${ }^{45}$ For a brief explanation of the difference between utilitarianism and wealth maximization, see Richard A. Posner, Economic Analysis of Law 12-17 (Aspen 5th ed 1998). Very roughly, utilitarians seek to maximize happiness, defined as the aggregation of private subjective desires; wealth maximizers seek to maximize efficiency, defined as the assigning of property rights (broadly understood) to those who value them most highly as measured by their willingness and ability to pay for them, taking into account the cost of any particular assignment.

${ }^{18}$ See, for example, id at 242-50.

${ }^{17}$ While taking for granted that blackmail is properly criminalized, Posner has explored the related question of why it is "punished severely in comparison with other nonviolent thefts." Posner, $141 \mathrm{U}$ Pa L Rev at 1836 (cited in note 2). Criminalizing blackmail, 
The one proponent of the law and economics thesis to have even attempted the necessary cost-benefit demonstration, Professor Joseph Isenbergh, has concluded that the marginal social benefit does not outweigh the marginal social cost. Isenbergh begins by observing that " $A$ gains no real control over disclosure from an unenforceable bargain with $B$. And if $B$ cannot assure $A$ of any increased control over disclosure, $B$ cannot extract much from $A$, and therefore has little reason to invest much effort in bargaining. ${ }^{348}$ Therefore, there is likely to be little (nonadventi-

Posner theorizes, reduces its occurrence by three mechanisms. It

(1) gives the blackmailer an incentive not to reveal the victim's secret after the victim has complained to the police, which makes such complaints more likely and therefore blackmail less likely; (2) makes it impossible to conduct blackmail in the open; (3) prevents the blackmailer from offering his victim a legally enforceable promise of secrecy.

Id at 1840. Posner recognizes that the latter two effects work independently of the severity of the penalty. He even notes that increasing penalties may actually decrease the deterrent value of the second effect because when blackmail cannot be conducted openly, it is most likely to be conducted by an intimate of the victim; when the victim and blackmailer are intimates, proof of the blackmail is more difficult; and when proof is less convincing, the likelihood that juries will convict stands in inverse proportion to the severity of the punishment. Id.

Thus, in Posner's argument, attaching severe penalties to blackmail can be justified only to the extent that the first alleged effect-which depends on Posner's assertion that the "blackmailer, once caught, usually will keep mum in an effort to obtain leniency," id at 1838-39-outweighs the second. But why would this be? Even putting aside skepticism that "keeping mum" will be a major element in a plea bargain, the dispositive issue concerns the extent to which the attraction of leniency depends upon the severity of the prescribed penalty. Although Posner does not elaborate on his contention that "[t]he first effect is enhanced by severe punishment," id at 1840, I suppose it is based on his assumption that the defendant's objective in plea negotiations is to purchase the largest possible reduction in sentence. If so, the likelihood of reaching a successful plea bargain is enhanced by longer potential sentences: the larger the possible penalty, the greater the deal the prosecutor can offer. But if the defendant is more interested in the length of the actual sentence imposed than in the magnitude of the difference between the actual and potential sentences, large penalties on the books can reduce the prospects for reaching a plea insofar as there exist any institutional and/or psychological constraints on the amount of time a prosecutor can bargain away. And if the defendant can only be induced to silence by large relative reductions of sentence, the severity of the prescribed penalty is mostly irrelevant. These are, of course, highly simplified assumptions. They nonetheless suggest that, if efficiency concerns justify criminalizing blackmail at all, the economic considerations Posner identifies are as likely to weigh in favor of lenient punishment as strict.

4senbergh, $141 \mathrm{U} \mathrm{Pa} \mathrm{L} \mathrm{Rev} \mathrm{at} 1928$ (cited in note 13). See also Posner, $141 \mathrm{U} \mathrm{Pa} \mathrm{L}$ Rev at 1841 (cited in note 2) (noting that the third of his proposed mechanisms by which criminalization deters blackmail "could be achieved without criminal law simply by making blackmail contracts unenforceable as a matter of contract law"). This proposition is slightly more problematic than Isenbergh acknowledges. Making blackmail agreements unenforceable might substantially deter payment when the blackmailer is not a repeat performer because the victim could not be sure that the blackmailer would remain silent. But repeat performers present a different case. Regardless of whether the contract is legally enforceable, the hypothetical blackmail firm that might arise were blackmail decriminalized would find a reputation for trustworthiness critical (the apparent irony not- 
tious) blackmail in a regime that seeks to deter blackmail simply by making blackmail agreements unenforceable as a matter of contract law. ${ }^{49}$

Of course, it is possible that there would be even less blackmail in a regime that made blackmail agreements unenforceable and barred blackmail through the criminal law. Noting the rarity of blackmail in the case law, Posner has speculated that the few reported cases accurately reflect a low incidence of the crime. Anticipating that potential victims would refuse to pay blackmail, he surmises, a vast number of would-be blackmailers choose not to risk the criminal penalty. ${ }^{50}$ This is unpersuasive. It is more likely that blackmail is far more frequent than the incidence of reported cases suggests, and that the low rate of prosecution reflects the substantial willingness of victims to pay. One would expect an economically rational blackmailer to conceive and propose a blackmail price low enough to reduce substantially the probability that his victim will report the blackmailer to the police rather than accept the deal. Thus, although the social cost of the blackmail prohibition is apparently low (commensurate with the infrequency of prosecution and conviction), the deterrent value of the criminal ban is likely to be as small or smaller. Because the goal from an economic standpoint is to achieve not maximum deterrence but optimal deterrence, it is hard to conclude that blackmail's criminalization is a good buy.

Moreover, the economic case against criminalization may be even stronger, for the blackmail ban might be positively counterproductive. As Isenbergh has explained,

if blackmail is made a crime, $A$ gains considerable control over disclosure from entering into a bargain with $B$, because $B$, by incurring the criminal exposure of a blackmailer, can now sell $A$ a much higher likelihood of silence. . . . The criminal prohibition of blackmail, therefore, makes the

withstanding). Such an entity would find ways to make its guarantee of silence credible. But this observation still does not warrant criminalization, for there are other ways to discourage Epstein's "Blackmail, Inc." (discussed in Section I.A.2 below). For instance, in addition to making blackmail contracts void, the state could ban blackmail advertising and/or withhold the benefits of incorporation from firms engaged in blackmailing.

${ }^{4}$ This conclusion is further reinforced when we re-examine Posner's three proposed mechanisms by which criminalization deters blackmail. As noted above, Posner himself recognizes that the third mechanism can be achieved without criminalization. See Posner, $141 \mathrm{U} \mathrm{Pa} \mathrm{L}$ Rev at 1840-41 (cited in note 2). Depending upon the degree of moral censure attaching to blackmail, the second mechanism could as well.

${ }^{50}$ Id at 1841. 
blackmail bargains entered into across the threshold of prohibition highly enforceable. ${ }^{51}$.

And if the would-be blackmailer anticipates that a consummated bargain will be meaningfully enforceable, he is more likely to commit the resources necessary to undertake the activity.

In short, making blackmail a criminal offense might deter some blackmail that would not be deterred in a regime that merely made the blackmail contracts unenforceable. But, if so, its deterrent effect is likely to be small. The ban might be moderately efficient or moderately inefficient. On the other hand, criminalizing blackmail might even increase its incidence. In that event, resort to the criminal law is inefficient-maybe substantially so. Given such indeterminacy, the proposition (necessary to the economic justification for criminalization) that the expected value of criminalizing blackmail is positive seems highly dubious.

The foregoing analysis supports three conclusions about the law and economics argument on blackmail. First, the economic approach fails to justify prohibitions against adventitious blackmail. Second, whether other major forms of blackmail are truly disadvantageous on law and economics principles is far from certain once one takes externalities into proper account. Third, it is unlikely that the economic argument warrants resort to the criminal law. Accepting the first and third of these conclusions, Isenbergh has argued that the law can adequately deter any inefficiency blackmail causes simply by making contracts of silence entered into between a blackmailer and his victim void and unenforceable, except for contracts involving adventitious blackmail. ${ }^{52}$

But if the economic approach to the blackmail puzzle leads ultimately to Isenbergh, then we should look elsewhere to solve it. For although he concludes confidently that "[t]here is no other way to explain the law of blackmail," posals to decriminalize certain types of blackmail reveal that the economists' purported explanation is no justification. Before we agree that commercial research, and even entrepreneurial, blackmail should be freed from the criminal law's grasp, we

"1 Isenbergh, $141 \mathrm{U} \mathrm{Pa} L \mathrm{Rev}$ at 1928 (cited in note 13).

${ }^{62}$ More precisely, in light of the difficulty in ascertaining whether given information was costlessly obtained, Isenbergh would, as a proxy, make all contracts to remain silent enforceable if the parties knew each other before the blackmail bargain. He would also make an exception to that exception in cases where the blackmail contract concerns silence about the commission of torts or crimes. Id at 1925-32.

s3 Id at 1921. 
would do well to search for an account more in tune with current law and common intuition.

\section{Richard Epstein: blackmail as the "hand-maiden to corruption and deceit."}

Professor Richard Epstein has proposed a different consequentalist solution to the blackmail puzzle. Although himself a prominent law and economics scholar, Epstein's specific concern is not the deadweight economic losses that trouble Posner, Ginsburg, and Coase. Instead, Epstein argues that blackmail is criminal because it has a necessary tendency to induce other acts of theft and deception, the criminalization of which is wholly unpuzzling. ${ }^{54}$ This difference notwithstanding, Epstein's theory suffers from some of the same flaws as does the argument from economic efficiency.

Epstein "begin[s] with a brief account of the moral theory of criminal responsibility" ${ }^{\prime 55}$ - to wit, that there is no criminal liability without mens rea and actus reus. Blackmail, he concludes, easily satisfies the mens rea requirement, for " $[t]$ he element of intent is always present in vivid form. ${ }^{36}$ But the actus reus requirement presents a problem. Only the threat or use of force or fraud can satisfy it, Epstein argues, ${ }^{57}$ and blackmail (ordinarily) involves neither. ${ }^{58}$ One could "argue that the threat to disclose is illegal precisely because the disclosure itself, if made, ought to be illegal. ${ }^{m 59}$ But this argument fails, Epstein concludes, because it "jettisons the basic theory of criminal responsibility by holding that deliberate acts, not involving the use of force or fraud, may themselves be regarded as criminal. 60

Epstein maintains that the solution to the blackmail puzzle appears when one imagines a world in which blackmail were legalized:

at Epstein, 50 U Chi L Rev at 553 (cited in note 2). Precisely why the traditional, unproblematic, crimes should be criminal is not clear from Epstein's essay. As we will see, however, Epstein's account of blackmail is incompatible with any plausible justification (beyond his own idiosyncratic interpretation of the actus reus and mens rea requirements) for the criminalization of common law larceny offenses.

${ }^{65}$ Id at 555.

${ }^{68}$ Id.

${ }^{57}$ Id at 555-57.

\& Epstein notes that blackmail can contain force or fraud, as, for example, when the blackmailer threatens to disclose information gleaned from stolen documents. Id at $\mathbf{5 5 8 .}$ But in such a case, making blackmail criminal presents no puzzle, for "[i]t is easy to regard blackmail as a criminal offense whenever the disclosure is itself regarded as wrongful." Id.

Id at 560.

so Id. 
[T]here would then be an open and public market for a new set of social institutions to exploit the gains from this new form of legal activity. Blackmail, Inc. could with impunity place advertisements in the newspaper offering to acquire for top dollar any information with the capacity to degrade or humiliate persons in the eyes of their families or business associates. ${ }^{61}$

The existence of Blackmail, Inc. would produce at least two undesirable consequences, Epstein claims. First, the greater prevalence of blackmail would lead to more blackmail victims and, consequently, greater incidences of theft and fraud by victims desperate to obtain the funds necessary to pay the blackmailer. ${ }^{62}$ Second, because Blackmail, Inc. would "recognize[ ] that its ability to extract future payments from [the victim] depends upon [the third party to whom the disclosure would be made] being kept in the dark," it would "instruct [the victim] in the proper way to arrange his affairs in order to keep the disclosures from being made. ${ }^{.63}$ In short, Epstein concludes, "[b]lackmail is made a crime not only because of what it is, but because of what it necessarily leads to. . . . [I]t is the handmaiden to corruption and deceit. $\$ 64$

Epstein's conclusion, however, does not follow from his analysis. The real thrust of Blackmail, Inc. is that blackmail is properly made a crime not because of "what it is," but only because of its consequences. Epstein's assertion that force and fraud exhaust the concerns of the criminal law necessarily entails that criminalization of blackmail would be impermissible (given that blackmail does not itself constitute fraud or force) but for the fraudulent conduct it engenders. In other words, Epstein's theory provides not only that the systemic consequences he identifies are sufficient for imposition of criminal liability as a general matter, but also that those consequences constitute a necessary condition for imposition of criminal liability in the particular case of blackmail. Were this true, the proper scope of the crime of blackmail would be substantially narrower than it is at present. Consider, for example, a blackmail proposal in which the blackmailer demands sexual favors for the nondisclosure of embarrassing information that the victim has no moral obligation to divulge (such as her own illegitimate birth). This form of blackmail would nei-

ald at 562.

id at 564 .

id.

a Id at 566. 
ther induce the victim to engage in theft or fraud nor encourage any "deception" that society has a legitimate interest in deterring. Under Epstein's reasoning, it should not be criminalized. ${ }^{65}$

A second problem with Epstein's theory is that the claim upon which it rests-that force and fraud demarcate the criminal law's proper reach-is extremely dubious. Even aside from "victimless" offenses such as gambling, prostitution, and drug use, criminalization of which is notoriously suspect on liberal principles, the state makes numerous activities criminal that appear not to involve either force or fraud. These offenses cover a wide range of conduct from statutory rape to indecent exposure to larceny by stealth. Conceivably, Epstein could respond either by articulating conceptions of force and fraud sufficiently expansive to encompass all of the foregoing activities or by explaining why it is morally unjustifiable for the state to make such conduct criminal. But he has not done so.

Finally, the internal logic of Epstein's theory is fundamentally flawed. Epstein maintains (1) that the "basic," "moral" theory of criminal law holds that acts not involving force or fraud may not themselves be criminalized, and (2) that actions that induce force and fraud may also be criminalized. ${ }^{6}$ This second principle is frustratingly underdeveloped. ${ }^{67}$ More profoundly, these two principles are not compatible: claim (2) empties claim (1) of any meaningful moral content.

Epstein claims that it is morally wrongful for the state to punish people for engaging in nonforceful, nonfraudulent actions. This assertion must rest on reasons, even though Epstein does not state what they are. Those reasons will be either deontological or consequentialist in nature. A deontologic reason would be that people have a moral right to be free from punishment by the state for actions not involving force or fraud, no matter what the consequences. But Epstein's second principle is inconsistent with this justification-it allows the state to punish acts outside these areas, if they lead to force or fraud. So claim (1) must rest on consequentialist reasons. But if Epstein allows such reasons, his ar-

${ }^{66}$ Unless, that is, the practical difficulties in excepting such cases from a general blackmail ban would be insurmountable or too costly-a contention Epstein does not make.

${ }_{66}^{6}$ Epstein, 50 U Chi L Rev at 555, 565-66 (cited in note 2).

" Consider, for instance, the pricing and marketing strategies of major sneaker manufacturers. Though we might not have predicted it ex ante, we now know that kids rob and kill for other kids' sneakers and for the money with which to buy sneakers. Under Epstein's principle, we could make it a criminal offense for Nike to advertise in inner cities or to price Air Jordans far out of the comfortable reach of the average low-income adolescent male. And the standards by which to measure whether we should are not at all apparent. 
ticulation of "the moral theory of criminal responsibility" seems too narrow: in principle, anything that leads to the same types of consequences as acts of force and fraud could be made criminal. This conclusion could be avoided, I think, only by adopting a consequentialist moral theory in which acts of force and fraud constitute the essential, irreducible units of measurement. Why this should be, though, is a mystery. Unfortunately, Epstein provides no explanation himself. It follows, then, that Epstein's assertion that "deliberate acts, not involving the use of force or fraud may [not] themselves be regarded as criminal ${ }^{968}$ must be understood either as a descriptive claim (in which case, as we have seen, it would be false) or as a rule of prudence; it is not a statement of politico moral obligation.

In sum, Epstein's theory fails for three reasons. First, it would leave a significant subset of blackmail-that which neither induces the victim to engage in theft or fraud nor encourages any deception-uncriminalizable. Second, it rests on the questionable moral principle that force or fraud should be necessary conditions for criminalization. Third, and fatally, were Epstein nonetheless correct that force or fraud should be necessary conditions for imposing criminal punishment, his further claim that it is morally justifiable to criminalize conduct that is not itself forceful or fraudulent, if that conduct encourages other acts of force or fraud, cannot be sustained.

3. Jeffrie Murphy: blackmail encourages invasions of privacy.

A third theory, proposed by Professor Jeffrie Murphy, ${ }^{69}$ exhibits similarities to both of the approaches already discussed. Like Epstein, Murphy focuses on the antisocial conduct that legalizing blackmail might encourage. Like proponents of the deadweight loss hypothesis, Murphy seems principally driven to explain and justify the distinction between blackmail and "other hard economic transactions. ${ }^{.70}$ Like both earlier approaches, however, Murphy's theory is substantially underinclusive and rests on contestable premises.

Murphy proceeds in three steps. He begins with twin assumptions about the moral underpinnings of the criminal law:

The first is that immorality should be a necessary condition for criminalization but not a sufficient condition. The second

* Epstein, 50 U Chi L Rev at 560 (cited in note 2).

- See Murphy, 63 Monist 156 (cited in note 2).

${ }^{70} \mathrm{Id}$ at 156. 
is that utilitarian considerations, though unsatisfactory in explicating the concept of immorality, are a reasonable basis on which to answer the question "Which of all immoral actions should be criminalized?"71

He then asserts that blackmail and hard economic transactions "are both intrinsically immoral (and immoral for the same reason-e.g., taking an unfair advantage of the victim's vulnerability). ${ }^{m 2}$ Third, he explains that utilitarian considerations support (1) criminalizing the blackmail of persons who are not public figures, because legalized blackmail would create a new incentive to invade the privacy of average persons ${ }^{73}$ and (2) not criminalizing hard economic transactions, because there is no apparent way to draw objectively sensible and enforceable lines between immoral and moral transactions. ${ }^{74}$

One problem with Murphy's theory should be apparent. As Lindgren has pointed out, Murphy's theory cannot justify criminalizing participant and opportunistic blackmail, because any invasions of privacy such forms of blackmail occasion would be unaffected by blackmail laws. ${ }^{75}$ There is, however, a far greater difficulty: Murphy's theory cannot survive on a bare assertion that blackmail is immoral because it takes unfair advantage of a vic-

31 Id at 163.

${ }^{72}$ Id.

${ }^{73}$ Noting that substantial economic incentives to invade the privacy of "public figures" already exist, Murphy would generally permit blackmail of such figures at rates that do not exceed the market price for the information in question. However, because concealing embarrassing information about some public figures can be harmful to the legitimate interests of a democratic citizenry, Murphy would bar even the "market price" blackmail of "public officials." Id at 164-65.

"Id at 163-66.

${ }^{76}$ Lindgren, 84 Colum L Rev at 690 (cited in note 2). Lindgren levels three other criticisms at Murphy's theory. According to Lindgren: (1) Murphy errs by assuming there is no market for embarrassing information about private individuals: spouses, employers, credit agencies, and potential business associates are all interested in details about nonpublic figures; (2) Murphy's proposed exception for market price blackmail is unconvincing and morally unacceptable; and (3) there is much embarrassing information about public officials the concealment of which appears morally unproblematic. Id at 692-94.

These latter three objections do not cut as sharply as Lindgren believes. First, that there is some market for embarrassing information about private individuals seems irrelevant. Murphy could respond that blackmail should be criminal so as not to increase substantially the existing incentives for privacy invasion. Second, intuitions about market price blackmail are more diverse than Lindgren assumes. See Section III.B.2. Third, Murphy concedes that some embarrassing information about public officials is not relevant to the public, but suggests that here line-drawing difficulties weigh in favor of the rule he crafts. Murphy, 63 Monist at 164 (cited in note 2). Lindgren provides no compelling reason to disagree with Murphy's judgment on this point. 
tim's vulnerability. ${ }^{76}$ Consider the example Murphy offers of a paradigmatic "hard economic transaction":

I know that your son, whom you love more than anything else in the world, is dying of leukemia. I also know two other things: (1) that he is a great baseball fan who would love to have a baseball autographed by Babe Ruth to cheer him during his final days and (2) that $\$ 6,000$ is all the money you have in the world. Now I happen to own the last such baseball available in the world, and I will make you a proposition-namely, to sell you this baseball for $\$ 6,000 .{ }^{77}$

That does sound hard. And let us agree that it is immoral as well. But Murphy does not claim that the baseball owner has a moral obligation to give the baseball to the dying boy. Presumably the owner is morally free to sell it to the boy's parents for a "fair" price. Additionally, there would seem to be circumstances in which other dispositions of the baseball would also be immoral because "unfair," such as dropping it in the Pacific Ocean.

This has several consequences for Murphy's theory of blackmail. First, if the baseball owner is morally free to sell his property for a fair price, the blackmailer should be too, whether that price is set by the "market" or by another means. That is, "the morality of the criminal law ${ }^{978}$ would seem to forbid criminalization of what might be termed "fair-price blackmail." Second, if it might be immoral for the baseball owner to refuse to deal with the boy's parents, it might be immoral for someone in possession of embarrassing information to reveal it instead of becoming a blackmailer.

These last objections are telling. Murphy is most readily grouped among those who would justify criminalizing blackmail on consequential grounds, for he emphasizes the ways that blackmail laws can encourage or discourage invasions of privacy. And yet he explicitly premises his theory on both deontological and utilitarian concerns. Ultimately, the most revealing aspect of his theory lies in its unexamined deontological basis. That the blackmail proposal is "unfair"-let alone why it is unfair-is far from transparently obvious. Murphy's "preliminary inquiry" rein-

${ }^{73}$ In fairness, Murphy does not say that "taking an unfair advantage of the victim's vulnerability" constitutes the whole of the immorality of blackmail and hard economic transactions; he says only that it is an example of their immorality. Murphy, 63 Monist at 163 (cited in note 2). But if there are other ways in which blackmail is "intrinsically immoral," id, Murphy does not hint at what they may be.

$\pi$ Id at 156-57.

78 Id at 163. 
forces the need to study carefully the arguments for blackmail's intrinsic immorality; blackmail's wrongfulness cannot be blithely assumed.

\section{B. Blackmail as an Inherent Wrong: Of Unconditional Acts and Conditional Threats}

As demonstrated, the consequentialist theories suffer from various analytical faults. Beyond that, they fail even to approximate common intuitions regarding what's wrong with blackmail. It should be no surprise, therefore, that many other theorists start from the assumption that blackmail is properly criminal because it is a nonconsequential moral wrong. Their challenge is to explain why the threat is wrong in a way that either distinguishes the threat from the unconditional performance of the act threatened or explains why unconditional performance of the act threatened should also be criminal. This Section considers four very different efforts to answer this challenge.

1. Feinberg and Gorr: the wrongful act.

In Harmless Wrongdoing, Professor Joel Feinberg advances a complex and nuanced argument that, at its core, argues that the morality of blackmail is a function of the morality of the act that the blackmailer threatens or offers. ${ }^{79}$ Under this view, the key is to determine whether unconditional performance of the act threatened or offered by the blackmailer would be wrongful. If so, blackmail is likewise wrongful, ${ }^{80}$ and wrongful to that same degree. Because blackmail, as a species of theft, is also harmcausing, it is consistent with liberal principles to make it criminal. Correspondingly, if neither the act threatened nor the act offered is wrongful, then the conditional blackmail proposition is also not wrongful and may not be made criminal.

Two illustrations are helpful. Because it is clearly wrongful not to report the identity of someone who has committed a felony, there would be nothing puzzling or problematic about criminalizing the conditional offer not to report a crime. (That society might opt not to criminalize unconditional performance of the

79 Feinberg, Harmless Wrongdoing at 240-58 (cited in note 2). Feinberg speaks of acts "threatened" and "offered" in recognition of the fact that blackmail is always a double conditional proposition of the form: if $-x$ then $y$; and if $x$ then $-y$, where the first statement is a "threat" and the second is an "offer."

${ }^{\infty}$ Although he recognizes numerous cases of "justified blackmail," id at 258-74, Feinberg presents them as piecemeal exceptions, not as examples shedding any light on the nature of the puzzle. 
underlying wrongful act is irrelevant, according to Feinberg; it is enough that society could reasonably decide to impose either criminal or civil sanctions. ${ }^{81}$ ) In contrast, Feinberg argues, a person who comes to learn of another's adultery will often have neither a moral duty to reveal that fact nor a moral duty to remain silent. Consequently, society could not justifiably impose a legal obligation, criminal or civil, upon persons either to disclose or not to disclose the commission of adultery. It follows, Feinberg concludes, that the corresponding blackmail proposal-call it "adultery blackmail" - should be decriminalized. ${ }^{82}$

Given that adultery blackmail might well be a modal case of the crime, Feinberg's conclusion is startling. Michael Gorr has tried to salvage Feinberg's basic approach by showing why it actually supports the morally intuitive conclusion that adultery blackmail is properly criminalized. ${ }^{83}$ Gorr begins by asserting, contrary to Feinberg, that every act likely to arise in situations involving blackmail is either morally obligatory or morally prohibited. He agrees that society should not impose a legal duty either to disclose or not to disclose adultery, but bases his conclusion on epistemic uncertainty: we may not know whether the consequences of such a disclosure would be morally beneficial or would cause unnecessary misery, ${ }^{84}$ and we may lack necessary information "about the prior distribution of moral rights and duties among the related parties." ${ }^{95}$ But for these considerations, Gorr argues,

there would be a morally conclusive reason for imposing on third-party observers a legal requirement either to report the occurrence of adultery or (depending upon the circumstances) to refrain from reporting its occurrence. It follows that, in the absence of such concerns, there would also be a morally conclusive reason for prohibiting the corresponding blackmail proposals since these would constitute attempts to

"In a similar vein, Professor Arthur Goodhart years earlier sought, by distinguishing between moral and immoral liberties, to downplay the lawfulness of the act a blackmailer threatens to perform. See Arthur L. Goodhart, Essays in Jurisprudence and the Common Law 175-89 (Cambridge 1931). He concluded that it is blackmail when the act threatened, though lawful, is immoral. Unfortunately, Goodhart's conception of immoral liberties appears much like Justice Stewart's conception of obscenity-although he may have known it when he saw it, he did not provide the tools necessary for others to draw the difficult lines. See Jacobellis $v$ Ohio, 378 US 184, 197 (1964) (Stewart concurring).

Feinberg, Harmless Wrongdoing at 246-49 (cited in note 2). (1992).

See Michael Gorr, Liberalism and the Paradox of Blackmail, 21 Phil \& Pub Aff 43

st Id at 55 .

${ }^{8}$ Id at 56, quoting Feinberg, Harmless Wrongdoing at 248 (cited in note 2). 
acquire some of the adulterer's assets either by offering to conceal what ought morally to be disclosed or by threatening to disclose what ought morally to be concealed. But, ex hypothesi, although such difficulties do serve to inhibit us from imposing duties with respect to the mere disclosure or nondisclosure of the adulterer's activities, they do not prevent us from imposing duties not to engage in the blackmailing of such persons. ${ }^{86}$

The crux of Gorr's claim appears to be that Feinberg errs by focusing seriatim on each leg of the double conditional that constitutes a blackmail proposal. We might not know which of the two acts-the one threatened or the one offered-would be immoral, but we do know that one of them must be. Consequently, adultery blackmail's wrongfulness derives neither from the act threatened nor from the act offered (because either might be morally permissible), but from the blackmailer's communicating a threat that will commit him to either divulging or remaining silent, depending on his victim's response. Adultery blackmail is wrongful, then, because the blackmailer knowingly takes an unjustifiable risk of committing an immoral act.

But this is surely wrong. Even accepting for the sake of argument Gorr's dubious assumption that one of the options must be-from a God's eye perspective-the morally obligatory course of action, the fact that the adultery blackmailer commits herself, at the moment of her threat, to risking an immoral act does not entail that taking that risk is itself an immoral act. Recall Gorr's moral-consequentialist claim that the effects of disclosure are morally relevant and that those effects may be difficult or impossible to predict. It follows that even the prospective discloser herself might not know whether her moral duty is to disclose or not to disclose. And if we do not believe that an actor knows where her moral duty lies, it makes no sense to hold her morally culpable for risking violation of that duty. Otherwise, any decisionmaking strategy one might use in a morally uncertain situationfrom flipping a coin to delegating the choice to a third partywould be morally equivalent to blackmail. Because Gorr provides no reason for believing this is $\mathrm{so}^{87}$ his effort to salvage Feinberg's thesis fails. ${ }^{88}$

${ }^{86}$ Gorr, 21 Phil \& Pub Aff at 56-57 (cited in note 83).

${ }^{87}$ At least one theorist has intimated that a coin toss is the morally preferable decisionmaking strategy for those forced to choose between harms in cases of moral uncertainty. See John M. Taurek, Should the Numbers Count?, 6 Phil \& Pub Aff 293, 303 (1977).

${ }^{83}$ Some threads of Gorr's analysis do hint toward a departure from Feinberg's belief 
2. Lindgren and Fletcher: the wrongful threat.

At the opposite pole from Feinberg and Gorr stand Professors James Lindgren and George Fletcher. Whereas the former pair contend that the blackmail proposal is morally equivalent to the act threatened or offered, the latter argue-for vastly different reasons-that the key to the blackmail puzzle inheres entirely in the wrongfulness of the threat.

In a highly influential 1984 article, Lindgren claimed to solve the blackmail puzzle by observing that the blackmail threat differs from ordinary and legitimate threats, such as a threat "to sell to someone else unless the buyer agrees to pay the price demanded," in that only the former involves using for one's gain leverage that properly belongs to another (for example, the adulterer's spouse). ${ }^{89}$ What makes the blackmailer's conduct distinct from legitimate threats, and therefore wrongful, Lindgren argues, "is that he interposes himself parasitically in an actual or potential dispute in which he lacks a sufficiently direct interest. What right has he to make money by settling other people's claims? ${ }^{390}$

At the heart of blackmail, then, is the triangular nature of the transaction, and particularly this disjunction between the blackmailer's personal benefit and the interests of the third parties whose leverage he uses. In effect, the blackmailer attempts to gain an advantage in return for suppressing someone else's actual or potential interest. The blackmailer is negotiating for his own gain with someone else's leverage or bargaining chips. ${ }^{91}$

Lindgren's approach has been subjected to extensive criticism that need not be repeated here in full. ${ }^{92}$ While Lindgren's theory enjoys claims to rough-though surely not perfect ${ }^{33}-$ de-

that the unconditional act and the conditional threat are morally equivalent. If Gorr means to claim that an "attempt to acquire some of the adulterer's assets" is itself a wrongful act that makes the blackmail proposal morally worse than the acts threatened and offered, his argument approximates Leo Katz's (discussed in Section I.B.3) and suffers from the same failings.

Lindgren, 84 Colum L Rev at 701 (cited in note 2).

Io Id at 702.

it Id.

"See, for example, Leo Katz, Blackmail and Other Forms of Arm-Twisting, $141 \mathrm{U} \mathrm{Pa}$ L Rev 1567, 1580-81 (1993); DeLong, $141 \mathrm{U}$ Pa L Rev at 1681-88 (cited in note 11); Walter Block and David Gordon, Blackmail, Extortion and Free Speech: A Reply to Posner, Epstein, Nozick and Lindgren, 19 Loyola LA L Rev 37, 51-54 (1985).

${ }^{*}$ Consider, for example, a threat by Nazis to march in Skokie unless the town's residents buy them off with a large cash payment. I assume that this is blackmail. If so, the Nazis are merely leveraging their own constitutional rights, which they are threatening to exercise as an instrument of cruelty towards the town's many Holocaust survivors. (It 
scriptive accuracy, its normative appeal is extremely weak, as Lindgren himself has conceded, ${ }^{94}$ because he provides no reason why using someone else's leverage for individual gain should be unlawful, let alone criminal. Furthermore, if the use of such leverage or "chips" is wrongful, it is not clear why squandering another's chips-by neither threatening nor making a given disclosure-is not likewise wrongful and thus properly criminal. ${ }^{95}$

Whereas Lindgren's theory amounts to an insightful description in futile search of a normative rationale, Fletcher relies on a novel and explicit theory of crime and punishment. ${ }^{96}$ The core concern of the criminal law, he ventures, is to deter and negate conditions of dominance and subordination. ${ }^{97}$ If so, there is no reason to criminalize the mere disclosure of embarrassing information. Once undertaken, the disclosure is over and done with. The blackmail threat to disclose the same information is another story. Precisely because of "the prospect of repeated demands," blackmail tends to create a continuing relationship of dominance and submission. In consequence, blackmail "is not an anomalous crime but rather a paradigm for understanding both criminal wrongdoing and punishment." 99

Though provocative, Fletcher's theory runs into a host of difficulties. Maybe the least troubling difficulty concerns Fletcher's foundational theory of crime and punishment. As Fletcher acknowledges, not all crimes-homicide is an obvious example-appear to implicate relationships of dominance and subordination. ${ }^{100}$

Second, even if negating dominance is of fundamental, perhaps defining, importance to the criminal law, Fletcher's theory is underinclusive. In response to the objection "that if the aftermath of the alleged blackmail is the determinative factor," the crime should be defined "as the second act of blackmail," Fletcher emphasizes that "the relationship of dominance and subordination comes into being as a result of the victim's making the first payment or engaging in the first coerced act of submission. The

could be argued that the Nazis are really leveraging the informational interests of the public-within or without Skokie-that might wish to view the march. But this is a forced and artificial construction. The public could not compel the Nazis to march if they chose not to, nor could the Nazis be viewed as having even a weak moral obligation to march.)

* See Lindgren, $141 \mathrm{U} \mathrm{Pa} \mathrm{L} \mathrm{Rev} \mathrm{at} 1988$ (cited in note 3).

*5 See Isenbergh, $141 \mathrm{U} \mathrm{Pa} \mathrm{L} \mathrm{Rev} \mathrm{at} 1917 \mathrm{n} 35$ (cited in note 13).

${ }^{\circ}$ George P. Fletcher, Blackmail: The Paradigmatic Crime, 141 U Pa L Rev 1617, 1618 (1993).

${ }^{n}$ Id at 1629-35.

Id at 1626.

9 Id at 1617.

${ }^{100}$ Id at 1635. 
dominance consists in the knowledge that the victim is now fair game for repeated demands. Dominance and subordination are states of anticipation." ${ }^{\text {"101 }}$ While this may be so, Fletcher's theory remains underinclusive insofar as it cannot justify criminalizing blackmail proposals that do not reasonably create apprehension of repeated demands. Consider a judicial nominee who has committed some minor indiscretion in his past-say he smoked marijuana, and inhaled-for which he is not ashamed but the disclosure of which he (rightly) fears might doom his nomination. Assume that Blackmailer approaches Nominee on the eve of the confirmation vote and threatens to disclose his prior drug use to the Senate unless Nominee pays $\$ 10,000$. If he does not fear disclosure after his confirmation, Nominee may accede to the demand without initiating a submissive relationship. Under Fletcher's theory, Blackmailer's conduct should not be criminalized-a conclusion contrary to prevailing law as well as, I would suspect, to common moral intuition.

The third problem with Fletcher's argument is the most profound. Properly, Fletcher does not aver that a relationship of dominance and subordination is sufficient to justify criminal punishment. After all, innumerable relationships-parent and child, employer and employee, teacher and student, etc.--exhibit aspects of dominance and subordination, yet raise no suspicion in the eyes of the law. Indeed, some such relationships-such as prison guard and inmate-are products of the criminal law. The existence of such a dynamic cannot be a sufficient condition for criminalization. As one of Fletcher's critics objected, "It must be the case, therefore, that the blackmailer's actions are somehow intrinsically wrong and unjustified." ${ }^{\text {102 }}$ Fletcher appears to agree with this observation, but does not believe it has any critical force:

Many words and expressions at hand express what is wrong with blackmail. In fact, too many things are wrong with it. Blackmail represents coercion of the victim, exploitation of the victim's weakness, and trading unfairly in assets or chips that belong to others. It represents an undesirable and abusive form of private law enforcement. It leads to the waste of resources so far as blackmailers are induced to collect information that they are willing to suppress for a fee. ${ }^{103}$

\footnotetext{
${ }^{103}$ Id at 1637-38.

${ }^{102}$ Id at 1636-37 (noting objection raised by Stephen Latham).

${ }^{103} \mathrm{Id}$.
} 
In short, Fletcher seems to suggest, of course blackmail is wrong and unjustified.

But Fletcher's litany of blackmail's evils cannot do the work he expects of it precisely because each (loaded) observation is so hotly contested. What makes blackmail "coercive" or "exploitative" in a morally meaningful sense? Why is trading on another's chips "unfair"? What moral significance should we attribute to the fact, if true, that, on balance, blackmail wastes resources? As this Section endeavors to demonstrate, these are challenging questions. Mere reference to theories that elicit, but do not convincingly resolve, them cannot answer what Fletcher seems to acknowledge is the crucial question for his theory: what about the blackmailer's actions creates a wrongful type of dominance?

3. Katz: the punishment puzzle.

A middle ground between the poles defined by Feinberg and Gorr on the one hand and Lindgren and Fletcher on the other has been carved out by Leo Katz in his imaginative contribution to the blackmail debate. ${ }^{104}$ In contrast to Feinberg and Gorr, Katz asserts that blackmail is morally worse than the act threatened. Unlike Lindgren and Fletcher, Katz denies that the act threatened might be a moral right. Instead, he insists that the act a blackmailer leverages into his threat is (1) a moral wrong, and (2) a relatively minor one at that. ${ }^{105} \mathrm{He}$ thus restates the blackmail puzzle as follows: "If revealing the infidelities is only a minor immorality, then how can the taking of money which the victim prefers to that minor immorality be anything more than a minor immorality itself?" ${ }^{106}$ More generally, given that a blackmail proposal consists of two analytically distinct elements-the blackmailer's threatened act and his attempt to secure the victim's resources-why should it be assigned the greater moral and legal censure that attaches to the latter element alone?

Katz responds to this question by introducing, and proposing to resolve, what he calls the "punishment puzzle," a conundrum he illustrates with the following hypothetical: Smithy the burglar breaks into Bartleby's house to commit larceny. Inside, he demands that Bartleby divulge the combination to his safe and threatens to beat Bartleby senseless if he does not comply.

\footnotetext{
${ }^{104}$ See Katz, $141 \mathrm{U}$ Pa L Rev 1567 (cited in note 92).

${ }^{105}$ See, for example, id at 1597 ("The blackmailer puts the victim to a choice between a theft (or some other criminal encroachment) and some other, minor wrong. ... To be sure, the wrong must not be too minor. ... But it need not-and this is the crucial point--be an immorality that comes anywhere close to being criminal.").

${ }^{106}$ Id at 1598 (emphasis altered).
} 
Bartleby declares that he cannot bear to part with the items in his safe (which have only sentimental value) and regrets that he will have to submit to the beating. Smithy batters Bartleby savagely and leaves. When Louie the burglar breaks into Bartleby's house the next night, the identical scenario transpires-with one exception. Just as Louie is about to strike Bartleby, he notices a scrap of paper containing the safe's combination. Despite Bartleby's plea that he would rather be pummeled than lose his goods, Louie opens the safe and leaves with the contents. ${ }^{107}$

The law, of course, would punish Smithy the batterer more severely than Louie the thief, and Katz approves. The criminal law, he argues, should not take account of a victim's idiosyncratic preferences. Whereas victims are concerned solely with harm, the law is concerned with the defendant's culpability, of which harm is but a minor ingredient. ${ }^{108}$ Hence "the lesson of the punishment puzzle": "when the defendant has the victim choose between either of two immoralities which he must endure, the gravity of the defendant's wrongdoing is to be judged by what he actually did (or sought to achieve), not by what he threatened to do. ${ }^{\text {109 }}$ Smithy is punished more severely than Louie because battery is morally worse than theft. For the same reason, the law rightly views blackmail in light of what the blackmailer intends to do-take money from one who does not want to part with it. Thus, to Katz, blackmail is a form of robbery-a graver offense than the act threatened. ${ }^{110}$

For all the wit and insight of Katz's effort, it fails to solve the blackmail puzzle. Katz simply asserts that the act the blackmailer threatens is immoral. However, as Lindgren has objected, "this merely assumes away the paradox, which is in part that often what the blackmailer threatens to do is a moral right."111 While Lindgren's claim that the threatened act is often moral demands qualification (because the act's moral status is far more complex and contingent than he recognizes ${ }^{112}$ ), his general point still holds: whether the act threatened is a moral right or a moral wrong (or something else) cannot be simply assumed without argument. ${ }^{113}$

\footnotetext{
${ }^{107}$ Id at 1582-83.

${ }^{100}$ Id at 1590.

${ }^{100}$ Id at 1598 .

${ }^{110} \mathrm{Id}$ at 1599.

${ }^{11}$ Lindgren, $141 \mathrm{U}$ Pa L Rev at 1977 (cited in note 3).

${ }^{112}$ See Section II.
}

${ }^{113}$ Even if Katz is correct that the act threatened is wrongful, his further contention that the threat is less wrongful than what the blackmailer "actually did (or sought to achieve)" is unpersuasive. See text accompanying notes $188-91$. We need a more developed 
4. Nozick: blackmail as coercion.

All of the nonconsequentialists are driven to explain why the blackmail threat is a moral wrong. In addition, each of the theorists so far discussed considers the moral status of the acts a blackmailer might threaten. The final theory here addressedwhich derives from Professor Robert Nozick's seminal study of coercion $^{114}$ - does not. This oversight is significant. Instead of solving the blackmail puzzle, the coercion thesis further complicates the moral relationship between the conditional threat (or offer) that constitutes blackmail and the unconditional performance of the act threatened (or offered).

Nozick's most familiar remarks on blackmail appear in his 1974 classic, Anarchy, State, and Utopia, during a brief exploration of the concept of "productive exchange."115 Most voluntary transactions are "productive" in the sense that they make both parties better off. Nozick proposes that an exchange between $A$ and $B$ is unproductive under the following circumstances: (1) $A$ is no better off as a result of the transaction than if he had nothing to do with $B$; and (2) if $B$ 's part of the transaction consists solely of abstaining from performing some action, $x, B$ did not propose to perform $x$ solely to sell $A$ his abstention. ${ }^{116}$ Blackmail, he notes, is one example of an unproductive exchange. ${ }^{117}$

If this discussion is to be read as an argument for blackmail's criminalization, two problems arise. First, it presents an inaccurate description of blackmail: the victim may prefer that the blackmailer exists. Imagine that Adulterer dumps Mistress, who then decides to reveal their affair to Wife. However, an advertisement for Blackmail, Inc. causes her to reconsider. Although she would like to hurt her ex-lover, a possible windfall is also attractive. She sells her love letters to the professionals who in turn sell them to Adulterer. Adulterer's acceptance of the blackmail of-

theory than Katz provides to understand why the blackmailer's attempt to secure his victim's resources is necessarily more wrongful than the act threatened.

${ }^{114}$ Although traced to Nozick, this basic approach has been elaborated by others. See, for example, Altman, $141 \mathrm{U} \mathrm{Pa} \mathrm{L}$ Rev at 1640-51 (cited in note 43).

${ }^{115}$ Nozick, Anarchy, State, and Utopia at 84-87 (cited in note 2).

${ }^{116}$ Id at 84-85. Gorr articulates Nozick's definition in similar terms. See Michael Gorr, Nozick's Argument Against Blackmail, 58 Personalist 187, 188 (1977). The principal difference between Gorr's definition and that presented in the text is that Gorr does not present the second criterion as a conditional. Under Gorr's definition, it is a sine qua non of an unproductive exchange that one of the parties sells forbearance from an act; in other words, if forbearance is not part of the transaction, the transaction cannot be unproductive. Nozick does not address this point explicitly. As note 127 indicates, however, I think Gorr's is not the better view.

${ }^{112}$ Nozick, Anarchy, State, and Utopia at 85-86 (cited in note 2). 
fer is arguably conclusive evidence that he is better off because of the blackmailer. ${ }^{118}$ This blackmail transaction is not unproductive.

Second, assuming that the blackmail deal is unproductive, the question remains why it should be illegal, let alone criminal. We expect consequentialists to disfavor such transactions. But, as we have seen, not even the law and economics theorists have credibly justified blackmail's criminalization. How Nozick could find such a justification, compatible with his libertarianism, is hard to fathom. As Gorr has argued, "the reasons which Nozick offers for prohibiting 'unproductive' exchanges could not plausibly be made to cohere with the principles that are generally taken to underlie a libertarian society." 119

This is a powerful objection. Indeed, it is so forceful as to invite us to question whether Nozick is in fact arguing that unproductive exchanges are ipso facto criminalizable. Unfortunately, Nozick is not entirely clear on this point. Careful attention to the structure of his argument, however, suggests that he does not mean to argue that the unproductiveness of an exchange is sufficient for the state to make it criminal.

The productive exchange test serves a very different function. Assume an action would violate the natural rights of others or, in Nozick's terms, would cross a moral boundary. May the state prohibit the action, Nozick asks, or may it only require those who undertake it to compensate individuals whose rights are thereby violated? ${ }^{120}$ If the latter, how does one set the proper compensation level? Ideally, the state should replicate the market price for the boundary crossing - that is, the price upon which the persons threatened by the conduct and the person who wishes to

\footnotetext{
${ }^{118}$ Nozick responds to this problem as follows: "To state the point exactly in order to exclude such complications is not worth the effort it would require." Id at $85 \mathrm{n}$ * (cited in note 2). Perhaps Nozick means to agree that the blackmail agreement in such circumstances is not "unproductive." The further implication that such instances should be lawful would make this a profound concession, deeply inconsistent with prevailing law. More probably, Nozick means that he could recraft his test for unproductive exchanges so as to make the deal between Adulterer and Blackmail, Inc. unproductive by definition. But the difficulty in justifying blackmail's criminalization would be exacerbated.

${ }^{11}$ See Gorr, 58 Personalist at 187 (cited in note 116). See also Murphy, 63 Monist at 158 (cited in note 2) (observing that Nozick argues that "blackmail should be prohibited because it is an unproductive economic exchange" and criticizing Nozick for failing to provide any argument for the proposition "that unproductive economic exchanges are $\mathrm{im}$ moral $l^{m}$ ).

${ }^{120}$ Nozick, Anarchy, State, and Utopia at 57 (cited in note 2). In the vocabulary famously introduced by Professors Guido Calabresi and A. Douglas Melamed, may the state employ property or liability rules for the protection of rights? See Guido Calabresi and A. Douglas Melamed, Property Rules, Liability Rules, and Inalienability: One View of the Cathedral, 85 Harv L Rev 1089 (1972).
} 
engage in it would agree in a voluntary transaction. However, the likely existence of a transactional surplus (where the minimum price acceptable to the seller is less than the maximum price acceptable to the buyer) makes it impossible to ascertain the hypothetical market price. And it would be unfair to allow the boundary crosser to appropriate all the benefits of the exchange by compensating the "seller" of the right in an amount (less than the market price) necessary to keep him on the same indifference curve. The impossibility of identifying a fair compensation price without ex ante bargaining between the parties is, for Nozick, one argument for allowing the state to prohibit conduct that would cause or risk a boundary crossing. ${ }^{121}$ However, Nozick continues, when the state does prohibit conduct that risks crossing the moral boundary of another, it should usually compensate the party whose liberty is thus infringed. ${ }^{122}$ Again the question arises of how much to pay. Just enough, Nozick answers, to keep him on the same indifference curve he would occupy were he not disadvantaged by the prohibition. ${ }^{123}$ In this case, that is, the state may appropriate the entire transactional surplus. Why? Because the exchange is "unproductive."

For present purposes, whether the foregoing argument is cogent is unimportant. What is important is that the productive exchange test is only a tool for determining how much compensation is due an individual whose risky conduct the state prohibits. Whether the state is justified in prohibiting particular conduct is a wholly separate question. ${ }^{124}$ In short, not only is the productive exchange test an implausible basis for making blackmail criminal, but Nozick should no longer be read to contend otherwise. This is not to claim, though, that he has nothing to say about blackmail's criminalization. But we must look elsewhere to find it.

The definition of an unproductive exchange Nozick offers in Anarchy, State, and Utopia closely tracks the test of coercion that he offered some years earlier when he argued (roughly) that a proposal is coercive if it is properly deemed a "threat" rather than an "offer." ${ }^{\text {"125 }}$ A proposal is a threat if it makes the recipient worse

${ }^{122}$ Nozick, Anarchy, State, and Utopia at 63-65 (cited in note 2).

in Id at 78-85.

${ }^{123}$ Id at 86-87. For preliminary remarks regarding Nozick's notion of "disadvantage," see id at 82-83.

${ }^{12}$ See id at $67 \mathrm{n}$ *.

${ }^{125}$ Robert Nozick, Coercion, in Sidney Morgenbesser, Patrick Suppes, and Morton White, eds, Philosophy, Science, and Method: Essays in Honor of Errnest Nagel 440, 447 (St. Martin's 1969). 
off relative to his expected baseline, where "[t]he term 'expected" is meant to shift between or straddle predicted and morally required."126 Insofar as we are seeking a justification for criminalizing blackmail, this approach seems more promising. ${ }^{127}$ Although the relationship between freedom and coercion may not be easy to articulate with precision, ${ }^{128}$ the two concepts plainly stand in rough opposition: generally, one who is coerced is at least to that extent unfree. Therefore, for one who values human freedom (as Nozick does), coercion is prima facie wrongful. ${ }^{129}$ So if a blackmail proposal is coercive, there is good reason to believe that it should be made illegal. ${ }^{130}$

On inspection, though, Nozick's "coercion" thesis proves no more satisfactory than the "unproductive exchange" rationale at solving blackmail's paradox. First, it is unclear whether most

${ }^{228}$ Id.

${ }^{127}$ In most cases, the tests for coercion and unproductive exchange come out the same. That is, a consummated exchange is "unproductive" if and only if the proposal that launched the exchange was a "threat." Such is the case, for example, with the illustration Nozick offers to elucidate the second criterion of an unproductive exchange:

If your next-door neighbor plans to erect a certain structure on his land, which he has a right to do, you might be better off if he didn't exist at all. ... Yet purchasing his abstention from proceeding with his plans will be a productive exchange. Suppose, however, that the neighbor has no desire to erect the structure on the land; he formulates his plan and informs you of it solely in order to sell you his abstention from it. Such an exchange would not be a productive one; it merely gives you relief from something that would not threaten if not for the possibility of an exchange to get relief from it.

Nozick, Anarchy, State, and Utopia at 84-85 (cited in note 2). As Nozick's last sentence suggests, the proposal leading up to the hypothesized unproductive exchange is a threatbecause it is coercive-not an offer.

But the equivalence between coercion and unproductive exchanges does not always hold. Imagine that your coworker announces that his daughter is selling Girl Scout cookies and that he will be taking orders. You subscribe for four boxes of Thin Mints at $\$ 2.50$ per box. Although you'd prefer the $\$ 10$ to the cookies, you estimate that to decline the offer might cause you some reputational harm, and you value the cookies and the preservation of your reputation more highly than $\$ 10$ plus a possible slight diminution of your office status. This is plainly an unproductive exchange-you would have preferred that your coworker had never mentioned his daughter and the cookies. But the offer to sell you Girl Scout cookies is not a threat (because it doesn't put you worse off than your expected or morally deserved baselines).

${ }^{123}$ See, for example, Nozick, Coercion at 440 (cited in note 125).

${ }^{1 \infty}$ See Altman, $141 \mathrm{U} \mathrm{Pa}$ L Rev at 1641 (cited in note 43).

${ }^{100}$ Note that Nozick's shift from viewing blackmail as unproductive (bad consequences) to viewing it as coercive (wrongful) justifies placing him in Section I.B rather than with the consequentialists in I.A. Not surprisingly, Nozick's excursus on "unproductive exchanges" has caused other commentators difficulty in characterizing his position on blackmail. See Gordon, $141 \mathrm{U} \mathrm{Pa}$ L Rev at 1758, $1772 \mathrm{n} 137$ (cited in note 1) (wondering whether Nozick's blackmail argument is deontological or consequentialist); Kathleen $M$. Sullivan, Unconstitutional Conditions, 102 Harv L Rev 1413, 1447 n 140, 1449 n 145 (1989) (noting both that Nozick has "used utilitarian grounds to defend the ban on blackmail" and that his theory "reflects conceptions of negative liberty"). 
blackmail proposals count as threats under Nozick's definition. As noted, the "expected baseline" upon which Nozick's theory depends is a function of empirical and moral components. Nozick proposes that the normal and morally required course of events usually coincide and, further, that when they do not, the latter ordinarily takes precedence over the former. ${ }^{131}$ This being the case, it becomes essential to know whether the "victim" of the garden variety blackmail proposal has a moral right to nondisclosure. Rights and duties being correlative, ${ }^{132}$ the question, in other words, is whether the blackmailer has a moral duty to remain silent. ${ }^{133}$ As we have seen, this is a tricky question. Nozick's analysis provides no answer.

Worse, no simple categorical answer can resolve the puzzle. If the answer is no-the blackmailer does not have a moral duty to remain silent-then blackmail is not coercive and Nozick leaves us no basis for prohibiting it. If the answer is yes, then, if Nozick has succeeded in justifying making blackmail criminal, he has done so only by advancing effectively the same solution as has Feinberg: if a blackmail proposal is coercive only because the act "threatened" is wrongful, then the propriety of criminalizing blackmail turns entirely on the morality of the act threatened. And this resolution of the puzzle raises the question why unconditional performance of the acts leveraged into blackmail proposals should remain lawful. After all, other instances of criminal coercion represent threats to perform illegal acts; just as the law prohibits the gunman from coercing his victim ("your money or your life"), so too does it forbid his shooting the victim without even having voiced a threat. In short, if Nozick's proposed solution (blackmail is criminal because it is coercive) is correct, it merely reformulates the puzzle-why should it be a legal right to perform what it is illegal to threaten?-without resolving it.

\section{Summary}

The failure of the theories assessed in Section I.A suggests that we cannot explain and justify blackmail's criminalization by

${ }^{131}$ Nozick, Coercion at $449-51$ (cited in note 125).

${ }^{132}$ Ordinarily, at least. For an argued qualification (that does not undermine the point in the body), see David Lyons, The Correlativity of Rights and Duties, 4 Nous 45 (1970).

${ }^{133}$ As Kathleen Sullivan has concluded, "coercion ... is inevitably normative, not merely descriptive, empirical, or psychological. It necessarily embodies a conclusion about the wrongfulness of a proposal, not merely the degree of constraint it imposes on choice." Sullivan, 102 Harv L Rev at 1443 (cited in note 130). See also id at 1448-50 \& n 142 (discussing the normative judgments underlying Nozick's and others' definitions of the baseline from which coercive proposals are measured). 
attending only to its supposed social consequences. Any satisfactory resolution of the blackmail puzzle must acknowledge and explain the moral wrongfulness of the blackmail threat. The failure of the theories assessed in Section I.B demonstrates: first, that there is a moral difference between blackmail and the unconditional performance of the act threatened or offered (that is, we cannot establish the moral character of a blackmail proposal simply by first determining the moral status of the act upon which the blackmail is predicated); and second, that one cannot explain this moral difference by treating the conditional threat or offer as a morally aggravating factor. One should thus question the dominant assumption of this latter group of theories-that we already know that the conditional blackmail proposition is morally worse than unconditional performance of the act threatened, and that it remains only to explain why. Section II is animated by the suspicion that blackmail remains puzzling because we have yet to understand how the threat and the act differ.

\section{A PROPOSED SOLUTION}

Those inclined toward two-part categorization could propose numerous ways to divide the universe of blackmail theories. As we have seen, the well-rehearsed distinction between deontological and consequentialist moral theory suggests a division between those scholars who urge that blackmail is criminal because it is wrong in itself and those who focus on the its allegedly adverse social consequences. Alternatively, it could be revealing to distinguish contributions based on the particular question they appear devised to answer. Most theorists view the blackmail puzzle principally as a challenge to understand why this conditional threat to perform a legal act is different from all other threats to perform legal acts; others propose to explain how this voluntary transaction differs from other voluntary transactions. Yet a third possible classification would track the familiar distinction between bottom-up and top-down modes of analysis. Whereas some writers attempt first to understand blackmail as a social phenomenon and only then to explain why some purportedly peculiar feature of the practice makes it a fit subject for the criminal law, others start with an explicit theoretical model of the criminal law and then seek to locate blackmail within the model.

This Section proceeds in the latter mode. Section II.A enumerates three independent conditions that might constitute at least prima facie justification for criminalizing particular conduct. Section II.B demonstrates that one of these three criteria justifies criminalizing "central case" blackmail-defined as a 
blackmailer's threat to disclose embarrassing information about his victim unless the victim pays him a specified sum. This demonstration constitutes what I have called the evidentiary theory. Section II.C summarizes the evidentiary theory and answers blackmail's two principal puzzles. It explains why blackmail is an exception to two general rules: that it should be legal to threaten what it is legal to do, and that voluntary transactions should be lawful.

\section{A. Criteria of Criminalization}

If we are to determine, in other than ad hoc fashion, whether it is justifiable to make blackmail criminal, we will first need standards or rules detailing when society may legitimately threaten criminal punishment. This Section sets forth three criteria that independently might explain and justify when society may criminalize given conduct. It then elaborates upon the onethe notion that a liberal society may criminalize morally blameworthy, harm-causing conduct-that provides the strongest basis for making blackmail criminal.

\section{General justifying aims.}

If a criterion of criminalization is not to be freestanding and arbitrary, it should rest on an understanding of what H.L.A. Hart termed the "general justifying aim" of the institution of punishment. ${ }^{134}$ By common consensus, there are two justifying aims. ${ }^{135} \mathrm{~A}$ consequentialist theory justifies punishment as a means to reduce socially undesirable behavior through such mechanisms as deterrence, incapacitation, and rehabilitation..$^{136}$ A retributivist theory, in contrast, justifies punishment on deontological grounds by the inherent rightness of inflicting retribution upon a wrongdoer. ${ }^{137}$ A point commonly overlooked is that a consequentialist

${ }^{134}$ H.L.A. Hart, Punishment and Responsibility 8-11 (Oxford 1968).

${ }^{135}$ See, for example, id at 8-13; Kent Greenawalt, Punishment, in Sanford H. Kadish, ed, 4 Encyclopedia of Crime and Justice 1336, 1336-38 (Macmillan 1983); George P. Fletcher, Rethinking Criminal Law 414-20 (Little, Brown 1978); Herbert L. Packer, The Limits of the Criminal Sanction' 35-61 (Stanford 1968); John Rawls, Two Concepts of Rules, 64 Phil Rev 3, 4-5 (1955).

${ }^{136}$ Most contemporary theorists espouse a consequentialist justifying aim. For a classic elaboration and defense, see Packer, Limits of the Criminal Sanction at 39-61 (cited in note 135).

${ }^{137}$ The most prominent contemporary advocate of this position is Professor Michael Moore. See, for example, Michael S. Moore, The Moral Worth of Retribution, in Ferdinand Schoeman, ed, Responsibility, Character, and the Emotions (Cambridge 1987). Unfortunately, the common formulation of retributivism as the theory that "[w]e are justified in punishing because and only because offenders deserve it," id at 181, speaks only to the 
justifying aim can itself be the product of either of two radically opposed ethical theories, depending upon what content is ascribed to the notion of "socially undesirable behavior." If the behavior sought to be reduced is deemed undesirable because it is thought to effect a net diminution in social welfare, then the justification is, at root, utilitarian. But it is a mistake to assert that the nonretributive justifying aim of punishment is inherently "utilitarian in nature." 138 One who justifies the institution of criminal punishment on consequentialist rather than retributive grounds might be seeking to prevent acts believed to be wrong in themselves. ${ }^{139}$ In this way, one could, as a matter of political theory, consistently defend punishment for consequentialist reasons as serving a deontologic moral theory. ${ }^{140}$

\section{Three criteria of criminalization.}

The foregoing brief review suggests three principal factors that, depending upon the particular justifying aim of punishment adopted, would be especially relevant in determining whether

justification for imposing punishment in any given case, not to the justification for the institution of punishment. See also id at $181 \mathrm{n} 1$ (adopting a conception of "moral culpability" that "does not presuppose that the act done is morally bad, only that it is legally prohibited"). As a justification for creating a system of criminal laws backed by threat of punishment, the notion that persons who break those laws deserve to be punished would be circular. Nonetheless, belief in the intrinsic moral worth-or perhaps duty, see id at 182-of punishing individuals for "morally bad" actions plainly implies a retributivist justification for criminalization as well as for punishment. Indeed, Moore himself conceives of retributivism as both a general justifying aim of criminal punishment and a justification for its imposition in a given case. See, for example, Michael S. Moore, Justifying Retributivism, 27 Israel L Rev 15, 16-17 (1993).

${ }^{138}$ See, for example, Richard J. Bonnie, et al, eds, Criminal Law 2 (Foundation 1997) (describing the view that "punishment is threatened and imposed in order to achieve beneficial social consequences" as "utilitarian in nature").

${ }^{100}$ This was St. Thomas Aquinas's justification for the institution of human, as distinct from divine, law. Since some persons

are found to be depraved, and prone to vice, and not easily amenable to words, it was necessary for such to be restrained from evil by force and fear, in order that, at least, they might desist from evil-doing, and leave others in peace, and that they themselves, by being habituated in this way, might be brought to do willingly what hitherto they did from fear, and thus become virtuous. Now this kind of training, which compels through fear of punishment, is the discipline of laws.

St. Thomas Aquinas, Summa Theologica I-II, Q 95, Art 1. Therefore, insofar as we speak of only two general justifying aims, it seems preferable to term them "consequentialist" and "retributive," see Fletcher, Rethinking Criminal Law at 415 (cited in note 135), saving the utilitarian label for one of the two broad species of consequentialist theories.

${ }^{340}$ This position might be internally inconsistent if one holds a strong Kantian belief that there is no moral value in performing the right action for fear of punishment. See Immanuel Kant, Grounding for the Metaphysics of Morals 399-401 (Hackett 1993) (originally published in 1785). But this is not a necessary view. 
particular conduct ${ }^{141}$ should be made criminal: (1) whether the conduct is utility reducing; (2) whether the conduct is wrongful in itself; and (3) whether commission of the conduct is morally blameworthy. This is not to say, though, that the presence of any one of the these factors alone permits a liberal society to impose criminal sanctions. As we have seen, a consistent utilitarian theory must account for the costs of trying to prohibit undesirable conduct. Also, a rule that would authorize criminal punishment for any wrongful or blameworthy conduct would prove unbearably intrusive. It seems necessary, therefore, to qualify the second and third factors with some form of harm principle in order to limit their reach.

These qualifications lead to three independent prima facie criteria for when a liberal society may employ the criminal lawcriteria that should appear as fairly obvious (if not logically necessary) derivations from the standard proposed justifying aims. Conduct may be made criminal if:

(1) it is likely in the aggregate to yield net adverse social consequences (taking into account the costs imposed by the criminal ban itself);

(2) it (a) tends to cause or threaten identifiable harm and (b) is morally wrongful in itself; or

(3) it tends both (a) to cause or threaten identifiable harm, and (b) to be undertaken by a morally blameworthy actor.

These three criteria are not identical. Although much conduct (consider the mala in se offenses of the common law) will satisfy all three, each justifies some use of the criminal law that the others cannot. The practical differences between the second and third criteria, on the one hand, and the first on the other, should be apparent: for purposes of the first criterion, it is irrelevant whether the conduct that is a candidate for being made criminal is wrongful on deontologic grounds or is ordinarily blameworthy in the absence of a criminal prohibition. ${ }^{142}$ And al-

${ }^{141}$ "Conduct" here and throughout should be understood broadly to connote any describable combination of action, attendant circumstances, results, and mental states.

${ }^{142}$ After conduct is criminalized in accordance with condition (1), commission of the proscribed conduct is ordinarily morally blameworthy insofar as it reflects the knowing violation of a valid criminal law. See, for example, Henry M. Hart, Jr., The Aims of the Criminal Law, 23 Law \& Contemp Prob 401, 416 (1958) ("[I]f the actor knowingly goes counter to a valid legislative determination that the risk he is taking is excessive, even though he himself does not believe it to be, there is an independent basis for moral condemnation in this deliberate defiance of law."). For this reason, a consequentialist general justifying aim can coexist with the retributive principle of distribution, which requires that punishment only be meted out to the morally guilty. See H.L.A. Hart, Punishment and Responsibility at 9 (cited in note 134). See also Rawls, 64 Phil Rev at 4-13 (cited in note 135); S.I. Benn, An Approach to the Problems of Punishment, 33 Phil 325 (1958). 
though the second and third criteria demand some harm, neither requires that the expected harm outweigh expected benefits. The distinction between the second and third criteria turns on the claim that an actor is not blameworthy for engaging in a wrongful action if, for example, he lacks information critical to determining its wrongfulness or acts out of a bona fide and reasonable judgment (albeit one a majority of society deems mistaken) that his act is morally justified. For example, a legislator who concludes that euthanasia is morally wrong but also believes that, in practice, the euthanizer rarely acts in a morally blameworthy fashion could vote to criminalize the conduct in accord with the second criterion but not the third. Conversely, an actor who causes harm for reasons that are not justified is deserving of blame regardless of whether the act is deemed wrongful in itself. To use a familiar example, if someone kills an assailant in a situation where the use of deadly force is justified because necessary for self-defense, but the killer is unaware of the necessity, the killing is justifiably made criminal under the third criterion but not the second. ${ }^{143}$

3. The third criterion: defining terms.

Provisionally accepting the foregoing criteria invites the question whether blackmail (however defined) satisfies any of them. My criticisms of the theories canvassed in Section I suggest that blackmail is not likely to satisfy either the first or the second. It is unclear, once one takes account of the costs imposed by the criminal ban itself, whether any substantial category of blackmail yields net adverse social consequences; and it seems extremely likely that a large subset of presently criminalized conduct-adventitious blackmail_-does not. Also, efforts to explain why the blackmail act is wrongful appear unable to answer the questions of whether and why the act threatened is likewise wrongful. Consequently, this Section endeavors to show that blackmail is properly criminal because it satisfies the third criterion. A successful demonstration will both explain why blackmail is criminal and amount to a conditional justification-conditioned, that is, on the validity of the claim that it is permissible for the state to criminalize conduct because it is morally blameworthy and harm-causing. ${ }^{144}$ Because the argument to follow will

${ }^{103}$ For an interesting debate over this issue, compare Paul H. Robinson, $A$ Theory of Justification: Societal Harm as a Prerequisite for Criminal Liability, 23 UCLA L Rev 266 (1975), with George P. Fletcher, The Right Deed for the Wrong Reason: A Reply to Mr. Robinson, 23 UCLA L Rev 293 (1975).

${ }^{14}$ Because this solution to the blackmail puzzle will rest on the third criterion, we need not at this time expressly affirm either a retributivist or consequentialist general 
necessarily depend on the particular content ascribed to "harm" and "moral blameworthiness," some explication of these notoriously ambiguous terms is in order.

In legal, as in common, parlance, "harm" can connote injury to an almost limitless variety of interests. A cursory review of existing crimes indicates that the law does recognize as "harm" injuries to, among other things, bodily integrity (homicide, rape, battery), psychic or emotional well-being (assault, stalking, hate speech, child pornography), property interests (theft, vandalism, trespass), public institutions and processes (treason, bribery of public officials, insider trading), and public morals (prostitution, obscenity, drug use, gambling). The important question, however, is normative: what types of harms may a liberal society rely on to justify limiting individual liberty? ${ }^{145}$ This is an extraordinarily challenging question, raising issues of kind and degree that have bedeviled some of our most prominent theorists of the criminal law. ${ }^{146}$ If a thoroughly developed, foundational answer to this question were necessary in order to resolve the blackmail puzzle, we would be in for a long digression indeed. Happily, such an account is not needed. As we will see, my contention that blackmail satisfies the harm requirement fits well within the existing legal landscape and is unlikely, I think, to strain our intuitions. For

justifying aim. The retributivist foundations of the third criterion should be self-evident. But I assume that (with one caveat noted below) the third criterion could also be comfortably grounded in a sufficiently expansive consequentialism-one that focuses not solely on the consequences of the conduct at issue, but also on, for example, the potential harm to the "social fabric" caused by failure to punish those who engage in such conduct, and the concrete future harms that might be averted by incapacitating and specially deterring one who has exhibited a potential predisposition to cause harm. Indeed, reasons such as these have fueled long-running suspicion that most self-proclaimed justifying-aim retributivists are really disguised consequentialists. See, for example, Gregg $v$ Georgia, 428 US 153, 237-41 (1976) (Marshall dissenting); H.L.A. Hart, Punishment and Responsibility at 9 (cited in note 134). For an extended recent argument that society can best serve utilitarian aims by structuring all punishment decisions in accord with the community's moral judgments of desert, see Paul $\mathrm{H}$. Robinson and John M. Darley, The Utility of Desert, $91 \mathrm{Nw}$ U L Rev 453 (1997).

The caveat: insofar as the third criterion rests on retributivist premises, we must be concerned with actual moral blameworthiness; insofar as it rests on a consequentialist interest in constructing a shared moral universe, it is the perception of moral blameworthiness that matters.

${ }^{145}$ See Cass R. Sunstein, What's Standing After Lujan? Of Citizen Suits, "Injuries," and Article III, 91 Mich L Rev 163, 188-91 (1992) (criticizing the notion that the shifting focus in standing jurisprudence from "legal injury" to "injury in fact" effected a change from a question of law to a question of fact, and observing that "the real question is what harms that people perceive as such ought to be judicially cognizable").

${ }^{145}$ The most thorough exploration of this question is found in Professor Feinberg's distinguished four volume work collectively titled The Moral Limits of the Criminal Law. See Joel Feinberg, Harm to Others (Oxford 1984); Offense to Others (Oxford 1985); Harm to Self(Oxford 1986); Harmless Wrongdoing (Oxford 1988). 
present purposes, then, it should be sufficient to observe that whether a claimed injury counts as a "harm" with which the criminal law will be concerned "is a product of legal conventions and nothing else." ${ }^{\$ 14}$

"Moral blameworthiness" is also a nebulous concept. Although all the factors of which it is a function cannot be fully elucidated in this space, a few guideposts can be marked. In the easiest case, an individual's conduct is morally blameworthy when his objective is to inflict harm-such as when he acts out of malice (in the lay sense) or spite. But this does not exhaust the subject. The average thief, after all, steals not in order to impose a loss on his victim, but for the purpose of obtaining a gain for himself. Yet this conduct, too, appears blameworthy-even absent a law prohibiting it. ${ }^{148}$ The category of "morally blameworthy" conduct, therefore, must be broad enough to include the conscious willingness to cause harm without adequate moral justification, where the amount and quality of justification required is commensurate with the magnitude of harm caused. Similarly, it should include the conscious willingness to risk harm to others without adequate moral justification. (Consider drag racers on public roads.) Lastly, an actor is morally blameworthy when his conduct reflects an unjustifiable failure to appreciate the risks he creates. ${ }^{149}$ Putting aside questions concerning the moral blameworthiness of negligent harm-causing conduct (which the blackmail puzzle does not implicate), we can articulate moral blameworthiness in terms of the actor's motivations for acting. Thus (as a first and rough pass), an actor has "morally bad motives"150 and is therefore morally blameworthy ${ }^{151}$-when he acts with the knowledge that his conduct will cause, threaten, or risk harm to others, unless: (1) he actually believes that his action will produce

${ }^{147}$ Sunstein, 91 Mich L Rev at 190 (cited in note 145) (discussing the "actual injury" requirement in standing doctrine).

${ }^{148}$ See note 142.

${ }^{\text {u* }}$ See Model Penal Code $\$ 2.02$ (ALI 1962) (defining culpability levels).

${ }^{150}$ In ethics, "wrongful" is sometimes limited to acts, whereas "bad" is applied to an actor's motives in performing an act. See, for example, William K. Frankena, Ethics 8-9 (Prentice-Hall 1963); Jerome Hall, General Principles of Criminal Law 141 (Bobbs-Merrill 1947). Following this usage, this Article speaks generally of "wrongful acts" and "bad motives." A "bad act" is one that is badly motivated, whether or not it is wrongful.

${ }^{181}$ Arguably, an actor may have blameworthy motives without being morally blameworthy himself, if he lacks moral agency. Because the law presupposes that people are moral agents, this qualification does not bear upon whether to make particular conduct criminal. For an argument that it should be afforded greater relevance at the punishment stage than present law allows, see Peter Arenella, Convicting the Morally Blameless: Reassessing the Relationship Between Legal and Moral Accountability, 39 UCLA L Rev 1511 (1992). 
more good than evil; (2) that belief is a but-for cause of his action; and (3) the standards the actor employs for measuring and evaluating "evil" and "good" in this case are defensible under common moral standards.

\section{B. Criminalizing Blackmail: Of Harm and Bad Motive}

With these preliminaries out of the way, we have reached the critical questions: (a) does blackmail (ordinarily) cause cognizable harm? and (b) does the blackmailer (ordinarily) harbor bad motives? $?^{152}$

\section{A direct approach.}

To some readers, "yes" is the obvious answer to both of these questions. Professor Wendy Gordon has opined that "the deontologic case against blackmail seems clear. One person deliberately seeks to harm another to serve her own ends-to exact money or other advantage-and does so in a context where she has no conceivable justification for her act."153 The task, though, is to explain how we know the blackmailer seeks to cause harm without adequate justification.

Professor Gordon offers a thoughtful and elaborate explanation, but not, I think, one that ultimately persuades. Inverting the familiar doctrine of double effect, ${ }^{154}$ Gordon proposes to demonstrate the wrongfulness of a blackmailer's motives by relying on her so-called doctrine of single effect, which holds that "when one's direct intent is to do harm, beneficial side-effects have little or no deontological significance. ${ }^{\$ 155}$ Under this principle, Gordon concludes,

the blackmailer violates deontological constraints if he threatens disclosure in order to obtain money or other advantage because his intent is directed to the money, not to

\footnotetext{
${ }^{152}$ Regardless of whether the third criterion for criminalization rests on consequentialist or retributive justifications, see note 144, it cannot require that the conduct examined always cause (or threaten) harm and be undertaken with bad motives. Such a requirement would make ex ante line drawing impossible. Although one or another more precise qualifiers might appear more apt on further scrutiny, "ordinarily" serves as a satisfactory placeholder-with the important qualification that it not be understood to require that harm or bad motives occur "more often than not." There is no a priori reason why making certain conduct criminal must be improper when "only," say, 40 percent of given conduct is undertaken with bad motives.

${ }^{153}$ Gordon, $141 \mathrm{U} \mathrm{Pa} \mathrm{L} \mathrm{Rev} \mathrm{at} 1758$ (cited in note 1).

${ }^{164}$ The doctrine of double effect provides that it is "morally permissible to do an act that has bad consequences if they are outweighed by the good, so long as the harms are not directly intended." Id at 1763 .

${ }^{135}$ Id at 1764-65.
} 
the [lawfulness of] the disclosure or beneficial side-effects that might be produced. These latter factors are thus outside the intent of the blackmailer in the same way the killing of civilians is outside the intent of the strategic bomber: if blackmail's purported beneficial effects were eliminated or if civilians were protected, the actors would go forward. Since the blackmailer's end is harm, the act is not redeemable by the possibility that some component of the means he uses might be lawful or beneficial. ${ }^{156}$

The greatest problem with this analysis is Gordon's assertion that "the blackmailer's end is harm." What does this mean? Surely not that his motive is to cause harm, for presumably the average blackmailer's motive, like that of the garden variety thief, is merely to obtain a personal benefit. Perhaps Gordon means that blackmail is wrong only because the blackmailer has no interest in benefitting his victim. ${ }^{157}$ But so what? Without more, Gordon seems merely to describe a narrow self-interest most observers would already ascribe to the blackmailer even without the benefit of her doctrine of single effect. Moreover, her doctrine does not explain why the criminal law should care about such self-interest.

Consequently, two questions remain. First, the question Gordon addresses but does not adequately answer: in what way is a blackmailer's motive bad? Second, a question Gordon overlooks: how does the blackmailer's motive differ from that of the person who discloses harmful information without first trying to sell his silence? I propose to answer these questions by tackling the latter one first, believing that we can best understand why blackmail is criminalized by examining whether our third criterion of criminalization justifies criminalization of the unconditional disclosure of information likely to be injurious to the reputation of another. ${ }^{158}$

\footnotetext{
${ }^{1 s s}$ Id at 1765-66.

${ }^{157}$ Gordon considers a "libertarian” objection:
}

[A]n ordinary buyer would be delighted to obtain goods without paying, and an ordinary seller would be delighted to obtain money without giving up goods. If so, the parties to the commercial transaction have the "real" or direct intent of extracting money or other advantage-just like the blackmailer.

Id at 1770. Not so, she counters, proposing that, as an empirical matter, most people value reciprocity in exchange. "Take away the component of the buyer or seller's activity that benefits others, and she will find the activity less attractive; if so, then under the DSE test, part of the 'real' or direct intent is to exchange and not to extract." Id at 1771.

${ }^{158}$ It will be apparent that we are entering through the first door-attacking the blackmail puzzle by focusing on blackmail as an exception to the rule that it should be legal to threaten what it is legal to do, rather than as an exception to the rule that volun- 


\section{Detour: criminalizing the unconditional disclosure.}

The third criterion, recall, requires that the conduct tends both to cause or threaten identifiable harm and to be undertaken by a morally blameworthy actor. Plainly, the simple disclosure of information likely to injure another's reputation satisfies the harm requirement (at least when the claimed injury is of a sufficiently substantial degree as to warrant society's protection ${ }^{159}$ ). Injury to reputation is clearly other-regarding harm. Moreover, it is a harm that has long been legally cognizable-civilly and criminally-under both common and statutory law. ${ }^{160}$ At this stage of the inquiry, it is irrelevant whether the disclosure is true or false; either can cause real harm. ${ }^{161}$ It is likewise immaterial whether disclosure causes greater aggregate benefit than aggregate harm, as may occur when an adulterer's infidelity is disclosed to the wronged spouse or when an embezzler's offenses are disclosed to his business associates. A weighing of harms versus benefits would be essential to an effort to criminalize the conduct in accord with the first criterion articulated above, which requires that the conduct yields net adverse social consequences. ${ }^{162}$ But it

tary transactions should be legal. See introduction to Section II. In Gorr's estimation,

most theorists have ... tended to suppose that there is nothing especially problematic about the fact that we permit blackmailers to do what they threaten, and that all that really needs explaining is how, in light of this, it could ever make sense to prohibit the threats themselves. My contention, however, is that this is precisely the wrong way to view the matter and that the key to resolving the paradox of blackmail (and to meeting some of the other important objections to its continued criminalization) is to determine just why blackmailers are given the liberty to do the acts that they threaten.

Gorr, 21 Phil \& Pub Aff at 44 (cited in note 83). Despite the rightness and importance of this insight, Gorr's argument that a given act and its corresponding blackmail proposal are morally equivalent fails for reasons already assayed. See notes 83-88 and accompanying text.

${ }^{139}$ Consistent with the maxim de minimis non curat lex, the mildly insulting or indiscreet tattle of everyday discourse does not count. See Restatement (Second) of Torts $\$ 559$ (1977) ("A communication is defamatory if it tends so to harm the reputation of another as to lower him in the estimation of the community or to deter third persons from associating or dealing with him.") (emphasis added).

${ }^{180}$ See Gertz $v$ Robert Welch, Inc, 418 US 323, 341-46 (1974). See also id at 341 (stating that "the individual's right to the protection of his good name 'reflects no more than our basic concept of the essential dignity and worth of every human being-a concept at the root of any decent system of ordered liberty" ${ }^{\prime \prime}$, quoting Rosenblatt $v$ Baer, 383 US 75, 92 (1966) (Stewart concurring).

${ }^{161}$ See generally Garrison v Louisiana, 379 US 64, 72 (1964) (acknowledging general "abhorrence that 'a man's forgotten misconduct, or the misconduct of a relation, in which the public had no interest, should be wantonly raked up, and published to the world, on the ground of its being true") (emphasis omitted), quoting Thomas Curson Hansard, ed, 69 Parliamentary Debates 1230 (Hansard 3d series 1843) (remarks of Lord Campbell); Bruce W. Sanford, Libel and Privacy $\S 6.1$ at 201 (Prentice Hall 1991 \& Supp 1997).

${ }^{102}$ See Section II.A.2. 
has no bearing on the permissibility of using the third criterion (or the second) to make reputation-threatening disclosures criminal. For purposes of the third criterion, to repeat, the "harm" condition requires only that the conduct at issue causes or threatens identifiable harm, not that the aggregation of all possible harms and benefits yields a net diminution of social welfare.

The second requirement of the third criterion, however-that the disclosure of reputationally harmful information be ordinarily undertaken with bad motives-is not satisfied. Doubtless some disclosures are malicious or unjustified. But many others are made with good motives-to protect a potential victim of a con man or to provide presumably helpful and deserved information to a benighted spouse, for example. It seems unlikely that the instances in which persons disclose reputationally harmful information with morally bad motives constitute a sufficiently large subset of all reputationally harmful disclosures to warrant criminalization under the third criterion. ${ }^{163}$

There is no reason, however, that an explicit description of motivation cannot be imported into a definition of the conduct to be criminalized. This being so, conduct described as "the morally blameworthy disclosure of information likely to harm the reputation of another" could be made criminal consistent with the third criterion (where, if necessary to satisfy notice requirements, "moral blameworthiness" is further defined consistent with my earlier discussion). In fact, through the law of criminal libel, many states have prohibited precisely that: by the time of the Supreme Court's 1964 decision in Garrison $v$ Louisiana, ${ }^{164}$ a majority of states had constitutional or statutory provisions that made truth a defense to a criminal libel prosecution only when "published with good motives and for justifiable ends." 165 The Supreme Court's holding in Garrison that the First Amendment prohibits states from prosecuting any but the knowing or reckless falsehood when the alleged libel relates to public affairs has led to judicial invalidation of several such statutes ${ }^{166}$ and to desuetude of many others. ${ }^{167}$ But neither Garrison nor the prospect that the Court may expand it to prohibit criminal libel prosecutions for

${ }^{163}$ Keep in mind that most gossiping does not inflict cognizable harm. See note 159.

${ }^{164} 379$ US 64 (1964).

${ }^{165}$ Id at 70-72 \& n 7. Although criminal libel was generally justified as a means to protect against breaches of the peace, see id at 67-68, some jurisdictions had expressly conceived of the offense as a means to guard against injury to the libeled party. See, for example, Gardner v Arizona, 15 Ariz 403, 139 P 474, 476-77 (1914).

${ }^{166}$ See, for example, Montana v Helfrich, 277 Mont 452, 922 P2d 1159, 1161 (1996) (citing cases).

${ }^{175}$ See, for example, Tollett $v$ United States, 485 F2d 1087, 1094 (8th Cir 1973). 
any maliciously defamatory statements absent proof of falsity ${ }^{168}$ is germane to the present inquiry, for First Amendment constraints are external to the criminal law proper. As far as criminal theory is concerned, the unconditional disclosure of harmful information, without more, is not properly made criminal; the morally wrongful disclosure is.

\section{Bad motive and the conditional threat.}

This discussion offers one sufficient response to Gorr's suggestion that we need "to determine just why blackmailers are given the liberty to do the acts that they threaten": ${ }^{169}$ the likelihood that such persons act with good motives seems too high to justify a criminal ban. But it does not directly explain the criminalization of blackmail. In order to solve that puzzle we might first examine how a state that criminalizes the disclosure of reputationally harmful information with malice or without justification might prove those factors in a given case. ${ }^{170}$ Because it is profoundly difficult to obtain direct evidence of an actor's mental state, ${ }^{171}$ this is a challenging task.

In theory, bad motivation might be provable in a variety of manners. Admissions by the defendant himself in conversation or private writings would be the best evidence. In certain circumstances, perhaps, the state might be able to rely on the fact that the defendant made the disclosure anonymously. ${ }^{172}$ How about evidence that the accused had offered to remain silent for a fee

${ }^{168}$ The Garrison Court explicitly left this question open. See 379 US at $72 \mathrm{n} 8$. A decade later, the Court again refused to decide "whether truthful publications may ever be subjected to civil or criminal liability consistently with the First and Fourteenth Amendments." Cox Broadcasting Corp v Cohn, 420 US 469, 491 (1975).

${ }^{169}$ See note 158.

${ }^{170}$ Many criminal libel statutes, following the common law, mitigated this problem by making good motive and justification affirmative defenses. See Garrison, 379 US at $70 \mathrm{n} 7$ (cataloguing state provisions). But a simple allocation of the burdens of production or persuasion (or both) to the defendant cannot eliminate all difficulty because the state must be prepared to introduce evidence of bad motive if the defendant invokes the defense. Furthermore, in criminal slander prosecutions the state often has the burden of proving bad motive. See, for example, California v Faber, 29 Cal App 2d Supp 751, 77 P2d 921, 923 (1938).

${ }^{171}$ See Kimberlin $v$ Quinlan, 6 F3d 789, 809 \& $n 11$ (DC Cir 1993) (Edwards dissenting), vacated and remanded, 515 US 321 (1995); Ginsburg and Shechtman, $141 \mathrm{U}$ Pa L Rev at 1864 (cited in note 2).

${ }^{172}$ See Pennsylvania $v$ Foley, $292 \mathrm{~Pa} 277,141$ A 50, 51-52 (1928) (affirming conviction under statute prohibiting "the sending of anonymous communications of a . . defamatory . : nature," and explaining that anonymous publications of defamatory material "show such a malignity of heart and a desire to do personal injury that the Legislature or the courts may properly hold that such publications are so far malicious or negligent as to be unjustifiable"). 
prior to making the disclosure? Does this tend to show the requisite blameworthiness?

Surely it is probative. Consider, for example, a criminal libel prosecution (in a jurisdiction where blackmail is legal) involving defendant's ( $D$ 's) disclosure of a husband's ( $H$ 's) infidelities to his wife $(W)$. Here, $D$ 's prior (unaccepted) offer to refrain, for a payment of $\$ 1,000$, from disclosing the adultery is circumstantial evidence that, when he proceeded to reveal $H$ 's secrets, $D$ was not motivated by loyalty to $W$, or by an interest in achieving some measure of corrective justice, or by devotion to The Truth. A reasonable factfinder could suspect that, had any of these interests motivated $D$, he would not have offered to sell $H$ his silence. This is not just a covert way of giving effect to the factfinder's own ethical belief that $D$ should not have offered to remain silent for individual gain. It is empirically true that people value goods and interests in diverse and incommensurable ways and, relatedly, that most people have internalized a norm against commodifying certain types of nonmaterial interests and obligations. ${ }^{173}$ It is therefore reasonable to assume that most people who recognize morally persuasive grounds for undertaking a given course of action would not offer to sell abstention from it for personal gain. ${ }^{174}$ At the same time, assuming a relative infrequency of unbridled malice, many people who make a given disclosure with morally blameworthy motives would refrain from making the disclosure if paid off. ${ }^{175}$ For these two reasons, the probability that a morally bad disclosure of adultery occurred after the discloser had offered to remain silent for a fee is greater than the probability that a morally good adultery disclosure occurred subsequent to such an offer. It follows that a prior conditional offer of silence is probative evidence that, in revealing $H$ 's infidelity to $W$, the defendant acted with the morally bad motives necessary to make his action

\footnotetext{
${ }^{173}$ For a thoughtful elaboration of these claims, see Cass R. Sunstein, Incommensurability and Valuation in Law, 92 Mich L Rev 779, 782-812 (1994).

${ }^{174}$ This is an empirical claim. Whether society should employ the criminal law for purposes of reinforcing or even prescribing norms of value incommensurability is a decidedly separate question. See id at 790-93. Precisely because so many people already do act in ways reflective of value incommensurability and resistant to wholesale commodification, it is a question we need not resolve in order to explain blackmail's criminalization. In other words, we are still proceeding in accordance with the third proposed criterion of criminalization, not the second.

${ }^{175}$ Recall that morally bad motives are not limited to circumstances in which the actor's purpose is to harm $H$, but include cases in which he acts with knowledge of harm to $H$ without actually harboring motives that would amount to adequate moral justification. Very possibly, $D$ did not reveal the harmful information for the purpose of injuring $H$. $D$ may have acted merely to avoid the loss of reputation he felt he would suffer by failing to carry out his threat.
} 
(taken with knowledge of the harm it would cause) morally blameworthy. ${ }^{176}$.

That the conditional threat is probative evidence making it more likely that the particular disclosure of adultery was morally blameworthy is important, but it is not yet what we need to know. The critical question is: how likely? Although it would be foolish to hope for much precision here, straightforward application of probability theory might allow us to hazard a very rough estimate. As Bayes's Rule teaches, the odds that the post-threat disclosure is morally blameworthy are the product of the odds that any given disclosure of adultery is morally blameworthy and the evidential value, or probative weight, of the conditional offer. ${ }^{177}$ For the reasons just discussed, the offer's probative weight is likely to be fairly high. That is, the conditional threat probably makes it significantly more likely that the disclosure was morally blameworthy. Absent any reason to suspect that only an insignificantly small percentage of all disclosures of adultery are badly motivated, it seems fair to conclude that it is "ordinarily"178 the case that the disclosure of adultery occurring after a conditional offer of silence is morally blameworthy. ${ }^{179}$

${ }^{178}$ To be sure, that the offer is probative, all things being equal, does not mean it establishes the proposition that $D$ lacked morally good motives when engaging in the disclosure. The assumed empirical fact that there exist individuals who would be motivated by morally permissible reasons were they to expose an adulterer and nonetheless would be willing to remain silent for payment entails that the evidentiary inference cannot be ironclad. Indeed, we can well imagine cases in which it is quite plausible that the defendant lacked bad motives when exposing $H$ 's infidelity. For example, $D$ might tell a compelling story of both his friendship with $W$ and a pressing need for funds (say, $D$ 's child needs an emergency operation) arising in sudden coincidence with his discovery of $H$ s adultery. Lacking any other source of income, $D$ decides, after painful soul-searching, to blackmail $H$ to obtain the desperately needed funds. When $H$ rejects $D$ 's offer, $D$ proceeds to spill the beans to $W$, believing as he had all along that $W$ had a strong moral claim to the information, and even feeling somewhat relieved to be "freed" to perform his moral duty. In this scenario-and by hypothesis only! $-D$ lacks bad motives when engaging in his harmcausing disclosure, notwithstanding his unsuccessful blackmail proposal. But this conclusion has no bearing on the pivotal question of whether a reasonable factfinder would view the unsuccessful blackmail threat as making it more likely that $D$ possessed bad motives. We are speaking of inferring bad motives, not deducing them, and the strength of the inference depends, here as elsewhere, upon the totality of circumstances. After all, if "[1]ife is the art of drawing sufficient conclusions from insufficient premises," Samuel Butler, The Note-Books of Samuel Butler 11 (Mitchell Kennerly 1913) (Henry Festing Jones, ed), no less is the criminal law.

${ }^{17}$ Bayes's Rule provides that the posterior odds are equal to the prior odds times the likelihood ratio. For a particularly lucid introduction to Bayesian probability, see Bernard Robertson and G.A. Vignaux, Interpreting Evidence: Evaluating Forensic Science in the Courtroom ch 2 (Wiley 1995).

${ }^{178}$ See note 152.

${ }^{179}$ This conclusion can be supported with an example based on conservative assumptions consistent with the foregoing discussion. Where $P(B \mid O)=$ the probability that a disclosure is morally bad given a prior conditional offer, $\mathrm{P}(\mathrm{G} \mid \mathrm{O})=$ the probability that a dis- 
Insofar as these assumptions hold true more generally, a state could, consistent with the third criterion of criminalization, make it a crime intentionally to disclose information harmful to the reputation of another after having first offered to remain silent for a fee. ${ }^{180}$ Because it is ordinarily, and uncontroversially, illegal to threaten what it is illegal to do, the state could also make it a crime to threaten to disclose information harmful to another after first having offered to remain silent only if paid. That, of course, is blackmail. ${ }^{181}$

Having reached blackmail in this roundabout manner, we are positioned to offer a conceptual definition of the offense: ${ }^{182}$

closure is morally good given a prior conditional offer, $\mathrm{P}(\mathrm{O} \mid \mathrm{B})=$ the probability of a prior conditional offer given that the disclosure was made with morally bad motives, and $\mathrm{P}(\mathrm{O} \mid \mathrm{G})=$ the probability of a prior conditional offer given a disclosure made with morally good motives, Bayes's Rule provides as follows:

$[\mathrm{P}(\mathrm{B} \mid \mathrm{O}) / \mathrm{P}(\mathrm{G} \mid \mathrm{O})]=[\mathrm{P}(\mathrm{B}) / \mathrm{P}(\mathrm{G})] *[\mathrm{P}(\mathrm{O} \mid \mathrm{B}) / \mathrm{P}(\mathrm{O} \mid \mathrm{G})]$

Assume now that the background probability that a disclosure of adultery is made with bad motives is .2 , that the probability that a disclosure made with good motives was made after a conditional offer of silence is .1 , and that the probability that a disclosure made with bad motives was made after a conditional offer of silence is .6. On these (concededly unverifiable) assumptions, the probability that an adultery disclosure made after a conditional offer of silence is morally blameworthy can be determined as follows:

$$
\begin{aligned}
& {[\mathrm{P}(\mathrm{B} \mid \mathrm{O}) / \mathrm{P}(\mathrm{G} \mid \mathrm{O})]=(.2 / .8) *(.6 / .1)} \\
& {[\mathrm{P}(\mathrm{B} \mid \mathrm{O}) / \mathrm{P}(\mathrm{G} \mid \mathrm{O})]=1.5} \\
& \mathrm{P}(\mathrm{B} \mid \mathrm{O})=1.5 *(1-\mathrm{P}(\mathrm{B} \mid \mathrm{O})) \\
& \mathrm{P}(\mathrm{B} \mid \mathrm{O})=.6
\end{aligned}
$$

Whatever the "actual" numbers might be (in some contrivedly empirical sense), social actors are likely to suspect that this figure is quite high, for the modern mind's strong preference for univocal, linear narrative is antagonistic to the psychologically more complex tales (as in note 176) that throw the evidentiary inference into question. See Richard K. Sherwin, Law Frames: Historical Truth and Narrative Necessity in a Criminal Case, 47 Stan L Rev 39, 40 (1994). And insofar as we might prefer to ground the third criterion of criminalization in a consequentialist (rather than retributivist) general justifying aim concerned with social reinforcement of moral norms, it is the perception, not the reality, of the incidence of morally blameworthy motives that matters. See note 144 .

${ }^{180}$ This is not to say that such conduct should be criminal. Each of the three criteria provides only prima facie justification for criminalizing conduct; none demands it. A legislature could choose not to criminalize reputation-threatening disclosures undertaken with morally bad motives if it concludes that such disclosures advance social welfare. Moreover, other legal norms, including a constitutional guarantee, might mandate noncriminalization. As noted earlier, the Supreme Court has already construed the First Amendment to prohibit criminal punishment of true speech regarding matters of public interest. See note 168.

${ }^{181}$ It should make no difference whether the state chooses to enact the first offense. Imagine that the state had criminalized both the act and the threat and then decided to repeal the first for practical reasons (perhaps because it was deemed too vague, or too likely to chill well-intentioned disclosures). There is no reason that it should have to repeal the second as well.

${ }^{182}$ In describing the definition as conceptual, I mean to emphasize that I do not intend here to propose a legal definition. The definition in the text does not correlate perfectly with blackmail as law and common parlance presently define it. More to the point, I do not suggest that this definition should be codified. I take it that the first step when drafting a 
blackmail is a conditional threat by $B$ to harm $A$ under circumstances in which a reasonable factfinder could infer with confidence sufficient for purposes of criminalization that if $B$ carried out his threat he would be engaging in harm-causing conduct with bad motives-specifically, that $B$ would lack morally adequate reasons for knowingly causing harm-yet in which the moral character of $B$ 's motives would have been opaque had he acted without having made the threat. Put otherwise, blackmail is a conditional threat to perform a legal but harmful act under circumstances where the threat itself provides reason for making the act criminal by suggesting that the actor would be inflicting harm knowingly and without good motives. ${ }^{183}$

\section{Summary: Resolving the Puzzles}

1. The principal puzzle: why the act is legal and the threat illegal.

The foregoing discussion and proposed definition should make clear why the threat is illegal and the unconditional performance of the threatened act is not. As many theorists have noted, there is a moral difference between the two. But, contrary to prevailing opinion, ${ }^{184}$ that difference is not that the threat is somehow a morally aggravating factor. In the usual cases, merely doing an act that has been leveraged into a blackmail proposal is morally indeterminate in two senses-it is not clearly right or wrong itself, and, all else being equal, it carries insufficient data to support a secure inference about the moral character of the actor's motives. The threat, however, is presumptively undertaken for bad motives. Insofar as we can explain why blackmail is criminal only in accord with the third criterion of criminaliza-

criminal law is to identify, as closely as possible, the true contours of the conduct we wish to proscribe. The set of legal rules consisting of both elements and defenses, crafted in response to that understanding, will inevitably be both over- and underinclusive in relation to the underlying conduct that society would ideally want to deter and punish. In this way, the legal definition will be a product of, but unlikely identical with, the conceptual definition.

${ }^{18}$ It follows that, where practicable, the state should except from the blackmail ban (through offense elements or affirmative defenses) conditional threats as to which the likelihood of bad motives if undertaken can be expected, ex ante, to be particularly weak. See Section III.

${ }^{184}$ See, for example, Katz, $141 \mathrm{U}$ Pa L Rev at 1595 (cited in note 92) (concluding that the blackmailer's "accommodation of the victim's preferences [by proposing, and agreeing, to remain silent for a fee] aggravates rather than improves his moral position"); Altman, $141 \mathrm{U} \mathrm{Pa} L \mathrm{Rev}$ at 1657 (cited in note 43). 
tion-which turns on the mental state and motivations of the actor-the blackmail threat has only evidentiary significance. ${ }^{185}$

Professor Wesley Hohfeld's distinction between "operative" and "evidential" facts provides a useful vehicle for understanding this bedrock point. According to Hohfeld, "[o]perative, constitutive, causal, or 'dispositive' facts are those which ... suffice to change legal relations." ${ }^{" 186}$ In contrast, "[a]n evidential fact is one which, on being ascertained, affords some logical basis-not conclusive-for inferring some other fact. . . . either a constitutive fact or an intermediate evidential fact." ${ }^{\text {"187 }}$ Plainly, the blackmailer's conditional threat is an operative fact under the existing law of blackmail. Indeed, to ask why blackmail is a crime while the act threatened is not is really only to inquire into why the threat is an operative legal fact. Ordinarily, a fact is operative under the criminal law because it has pre-legal constitutive or causal significance. That the deceased was a human being is an operative fact under the law of homicide, for example, because something of independent importance turns on the fact that it was a person (rather than, say, a chicken or a tomato plant) that was killed. The evidentiary theory of blackmail recognizes that the blackmail threat is not this type of operative fact. Fundamentally, the conditional threat is not "operative" at all, but evidential-it "affords some logical basis (not conclusive) for inferring some other fact," namely, that the threatener had morally blameworthy motives. In short, for purposes of explaining the surprising conjunction that it is illegal to make a blackmail threat while it is legal to engage in the conduct threatened, the actor's bad motivation, not the threat itself, is properly viewed as "operative."

Not only is the threat to disclose embarrassing information not necessarily morally worse than the unconditional disclosure of information absent the threat, but it may well be that a given

\footnotetext{
${ }^{185}$ To deny any categorical moral difference between wrongful disclosure of damaging personal information about a person and blackmailing him over the same information is not to assert that the criminal law need punish the behaviors with equal severity if the state chooses to criminalize them both. Deciding how much punishment to mete out for particular offenses involves different considerations than does determining whether to criminalize particular conduct. Although an exploration of the former question is well beyond the scope of this Article, it is worth observing that the two varieties of conduct differ in potentially relevant ways. For example, Fletcher is surely right to emphasize that blackmail is particularly harmful because it is usually a repeat affair (although his conclusion that blackmail is therefore a "paradigmatic" crime seems a non sequitur). Fletcher, $141 \mathrm{U} \mathrm{Pa} \mathrm{L}$ Rev at 1626 (cited in note 96).

${ }^{105}$ Wesley Newcomb Hohfeld, Some Fundamental Legal Conceptions as Applied in Judicial Reasoning, 23 Yale L J 16, 25 (1913).

${ }^{100}$ Id at 27.
} 
discloser of information acts with even greater moral blameworthiness than does the ordinary blackmailer. Consider the case of Charles Augustus Milverton, the master blackmailer concocted by Sir Arthur Conan Doyle. ${ }^{188}$ Milverton's method

is as follows: He allows it to be known that he is prepared to pay very high sums for letters which compromise people of wealth and position. ... Everything which is in the market goes to Milverton, and there are hundreds in this great city who turn white at his name. No one knows where his grip may fall, for he is far too rich and cunning to work from hand to mouth. He will hold a card back for years in order to play it at the moment when the stake is best worth winning. ${ }^{189}$

Reasoning that one cannot "compare the ruffian who in hot blood bludgeons his mate with this man, who methodically and at his leisure tortures the soul and wrings the nerves in order to add to his already swollen money-bags," Sherlock Holmes deems Milverton "the worst man in London."

Maybe so, but Milverton could be worse still. Imagine that he is as cunning and ruthless as Conan Doyle represents, but that he is motivated by something other than money. Already rich as Croesus, Milverton acquires information not to blackmail but merely to reveal, for he takes greater pleasure in causing pain and suffering than in aggregating further wealth. This Milverton would never consider offering his victim a choice of harms; he will disclose every bit of embarrassing and discrediting information he obtains-at the moment most damaging to its subject. To be sure, this Milverton is a less likely character than Conan Doyle's because spite is a less common and less all-consuming motive than avarice ${ }^{191}$ (and because, unlike blackmail, the enterprise of revealing information is not likely to be self-financing). But is there any doubt that the "Master Fink"-who "methodically and at his leisure tortures the soul and wrings the nerves" in order to torture the soul and wring the nerves-could more fairly lay claim to the title "the worst man in London" than could the Master Blackmailer?

\footnotetext{
${ }^{188}$ See Arthur Conan Doyle, The Adventure of Charles Augustus Milverton, in 1 Sherlock Holmes: The Complete Novels and Stories 791 (Bantam 1986). Milverton is discussed in Hepworth, Blackmail at $46-47$ (cited in note 19).

${ }^{189}$ Doyle, Adventures of Charles Augustus Milverton at 792.

${ }^{190}$ Id.

${ }^{191}$ It is partially for this reason that the evidentiary inference is probative. See text accompanying notes 174-75.
} 
All this suggests that, First Amendment considerations aside, the morally blameworthy disclosure of harmful information could be made criminal. However, because the state would have to prove that the defendant had a bad motive, successful prosecutions would be rare. At the same time, adoption of such a crime would impose many costs-for example, it would waste resources in failed prosecutions, chill the disclosure of socially useful facts, and likely sow disrespect for the law. Moreover, when the state did successfully prosecute, it would likely do so on the strength of evidence that the defendant had first attempted to blackmail the victim-in which event a prosecution for the crime of blackmail would be available anyway. For all these reasons, a decision not to enact such a law seems, at the least, prudent.

2. The secondary puzzle: distinguishing other voluntary transactions.

The answer to the second blackmail puzzle should be clear now, too. The law and economics scholars have tended to suppose that blackmail is a voluntary exchange between the blackmailer and victim but have concluded that the practice is nonetheless properly made criminal (at least in its paradigmatic form) because of the costs it imposes on other persons who are not parties to the transaction (including society at large). ${ }^{192}$ The evidentiary theory demonstrates that this premise is mistaken. While not denying that blackmail might harm third parties, it insists that the blackmail transaction is not voluntary in the first place.

As Professor Kathleen Sullivan has cogently explained, coercion "is inevitably normative . . . . It necessarily embodies a conclusion about the wrongfulness of a proposal. ${ }^{193}$ Surely, then, if a proposed course of action is wrong in itself, the conditional proposal is coercive (at least where the recipient of the proposal views the proposed action as detrimental to her own interests). But normative concerns are not limited to whether a proposal is inherently wrongful in either an objective or conventional sense; they extend as well to considerations of the moral character of an actor's motives for advancing a proposal that is itself morally ambiguous. Although clarity may sometimes be enhanced by terming an immoral proposal "wrongful" and an immorally motivated one "bad, ${ }^{\text {"194 }}$ we should not insist on the distinction at all costs. To the contrary, inasmuch as the conditional offer tends to reveal

\footnotetext{
12 See note 12.

${ }^{193}$ Sullivan, 102 Harv L Rev at 1443 (cited in note 130).

${ }^{13}$ See note 150.
} 
that the actor would lack morally adequate reasons for engaging in his threatened course of conduct, a refusal to recognize this particular proposal-made by this particular actor on this particular occasion-as "wrongful" beclouds more than it illuminates. Put otherwise, perhaps we should not rigidly insist that the moral character of acts be judged independently of the motives behind them. ${ }^{195}$ It follows that the blackmail victim is just as coerced as the holdup victim. Because people's assumptions about the intentions and motivations of others are central to the way they experience social intercourse, ${ }^{196}$ victims of blackmail, just as much as victims of holdups, are likely to view the threatener's proposal as a "threat," not an "offer," and to experience themselves as acting under duress. ${ }^{197}$ In neither case is the victim's acquiescence "voluntary" in a sense sufficiently robust to counsel against societal interference with his purported transactional autonomy.

\section{Testing THE EVIDENTIARY THEORY: THE CENTRAL CASE AND BEYOND}

After demonstrating that the evidentiary theory explains criminalization of a threat to expose an adulterer, the previous Section moved quickly to contend that the theory generally supports criminalizing threats by $B$ to reveal embarrassing information about $A$ unless $A$ pays $B$ to remain silent. But this particular conduct-which might be called "central case" blackmail-far from exhausts the universe of potential blackmail. The act a blackmailer threatens need not be to disclose information. The blackmailer need not demand money. Furthermore, even central case blackmail (as somewhat arbitrarily defined) encompasses numerous subcategories that perhaps warrant further exploration. Should it matter, for example, if the information $B$ threatens to reveal is not merely embarrassing but relates to $A$ 's commis-

${ }^{198}$ See Steven Sverdlik, Motive and Rightness, 106 Ethics 327, 327 (1996) (setting forth, and criticizing, the "very widely accepted and rarely questioned" proposition in moral theory "that the motive of an action never determines whether it is right or wrong").

${ }^{196}$ See H.L.A. Hart, Punishment and Responsibility at 182 (cited in note 134) (observing that "persons interpret each other's movements as manifestations of intention and choices, and these subjective factors are often more important to their social relations than the movements by which they are manifested or their effects").

${ }^{197}$ Put otherwise, theorists who deny that blackmail is coercive or that the blackmail victim acts under duress fail to understand or validate the victim's perspective as participant in a particular human drama. Were she to articulate her sense of being coerced, the victim would be more likely to emphasize the particular complaint that her blackmailer ought not to do as he threatens, not the more abstract objection that what the blackmailer threatens ought not be done. 
sion of a crime? Or what if $B$ "demands" of $A$ no more than $B$ could get from other market actors for the same information? Questions like these have occupied, and at times confounded, blackmail theorists. Accordingly, any adequate theory of blackmail must show how the law should treat these and other distinctive cases. This Section explores several of these variations and seeks to demonstrate that the evidentiary theory accounts well for common moral intuitions regarding the proper scope of a criminal prohibition.

\section{A. A Blackmail Test}

As Feinberg has observed, every blackmail proposal is a double conditional of the form "if $-x$ then $y$; and if $x$ then $-y$." The first conditional is a "threat" the second an "offer"; $y$ is the "act (threatened)," $-y$ the "act (offered)"; $x$ is the "demand." 198 In order to explore further the validity and utility of the evidentiary theory, this Section proposes a test to assess whether any given proposition that meets blackmail's formal requirements should be deemed "blackmail" for purposes of the criminal law. The test has four steps.

First, assume the actor simply performed the act threatened $(y)$ and ask whether that action is itself criminal. If the answer is yes, then the proposition is just a threat to perform a criminal act and is not blackmail. There is nothing puzzling about criminalizing a conditional threat to commit a crime, and we would confuse an already confusing subject by bringing such threats within the rubric of blackmail. The proposition is usefully and conventionally labeled "extortion" or "criminal coercion."

Second, if the act, $y$, is not itself criminal, ask whether it causes or threatens legally cognizable harm. If it does not, then it cannot be made criminal (or at least not on the strength of the third criterion of criminalization). Certainly, one might be tempted to call at least some propositions that fall out at this stage "blackmail," and the designation could be appropriate so long as we are speaking of moral rather than legal offenses. However, the purpose of this inquiry is to determine the proper scope

\footnotetext{
${ }^{100}$ Feinberg, Harmless Wrongdoing at 246-47 (cited in note 2).

${ }^{100}$ As Feinberg has explained, distinctions between such terms as "extortion" and "blackmail" have not been consistently observed. Id at 240-42 (classifying extortion and blackmail within the broad genus of theft). The "blackmail" label is best reserved for threats to perform a legal act, while threats to commit an unlawful act are either "extortion" (if the threat is to be carried out in the future) or "robbery by threat" (if the threatened action is immediate). See, for example, Shavell, $141 \mathrm{U}$ Pa L Rev at 1877 \& $\mathrm{n} 1$ (cited in note 23) (adopting a similar nomenclature).
} 
of a criminal prohibition. Accordingly, when performing the act threatened would impose a "disutility" that society would not deem a legal harm, this step of the test concludes that the proposition is not blackmail.

If the act is not criminal yet causes harm that is cognizable for purposes of the criminal law, the next task is to explore whether the actor has morally bad motives. The third step, therefore, is to identify which particular reason(s) for action would have made the actor's harm-causing conduct morally justified. The fourth step is to ask whether the actor's offer not to perform $y$ on condition $x$ makes it materially less likely that he was actually motivated by any one of the morally justifying reasons identified in the third step. ${ }^{200}$ If so (and if that perceived likelihood is sufficiently low) the original proposition should be condemned as blackmail. ${ }^{201}$

As should be expected; this test supports criminalizing $B$ 's threat to reveal $A$ 's adultery unless $A$ pays $\$ 1,000$. The first step is to disregard the threat and offer, and to assume that $B$ simply disclosed $A$ 's adultery. That is not a crime. Next, ask whether that act causes legally cognizable harm. It does. ${ }^{202}$ Third, identify the motives $B$ must have had in order to keep his disclosure from being morally blameworthy. Fourth, consider whether $B$ 's preceding offer to preserve $A$ 's secret upon payment of $\$ 1,000$ makes it materially less likely that $B$ did in fact act because of the motives hypothesized at the third step. We have already answered this question in the affirmative. ${ }^{203}$

${ }^{200}$ Frequently, such a conclusion will be warranted when the apparent purpose of the offer is incommensurable with the hypothetical "legitimate" purposes animating the act, $y$.

${ }^{\infty 1} \mathrm{We}$ are still not in a position to specify what the threshold likelihood should be. See note 152. The familiar standard of proof in criminal cases might suggest that conduct should be excluded from the criminal ban unless the fourth step permits one to conclude beyond a reasonable doubt that the actor would have lacked morally justifying motives for engaging in act $y$. This formulation would be correct were the question whether the actor should be convicted under a statute that prohibits the commission of harm-causing conduct with morally bad motives. The standard need not be so strict, however, when the question is whether specific definable categories of conduct should be prohibited by the criminal law, for overbreadth in criminalizing conduct implicates different considerations than does overbreadth in convicting individuals. So long as a criminal law gives fair notice of proscribed conduct, and individuals are not convicted under such a statute unless they are found to have engaged in the proscribed conduct "beyond a reasonable doubt," criminalization can be justified on a substantially lesser showing. However, because we will be unable to progress far in articulating the proper required showing without first adopting a particular general justifying aim of the criminal law, perhaps the best we can do at present is to tolerate this vaguely worded test and to focus not on the bottom-line likelihood that the actor would have possessed bad motives had he engaged in the conduct threatened, but rather on the probative weight the offer lends toward that inquiry.

${ }^{20}$ See note 160 and accompanying text.

${ }^{203}$ See notes 173-78 and accompanying text. 
This brief application of the blackmail test should suggest that the test is simply a more formalized (though not a purely mechanistic) articulation of the evidentiary theory from Section II. As such, it does not demonstrate that either the test or the theory is correct. A formal proof is, in any event, impossible. The following Section does the next best thing: attempting to show that the results of the evidentiary theory of blackmail and its test conform either to existing strongly shared intuitions, or to judgments that can be accepted upon reflection.

\section{B. Applications}

This Section analyzes seven categories of conduct, both within and without the central case of blackmail, that challenge either the criminalization of blackmail in toto or the integrity of any unified explanation of the crime. These seven categories are: (1) "hard" commercial bargaining; (2) market price blackmail; (3) threats to expose a crime; (4) threats by the victim of the person blackmailed; (5) public interest blackmail; (6) noninformational blackmail; and (7) bribery. The inquiry throughout is whether this particular category of conduct is criminalizable as a matter of principle because it satisfies the twin requirements that it ordinarily cause harm and ordinarily be undertaken with morally bad motives. Whenever the answer is no, one must ask whether it would be practical to carve out an exception for that category from a general blackmail ban. Since this Article attempts only to answer the broad theoretical questions regarding blackmail, it does not explore the particular issues this second question raises; doing so would amount to proposing a model blackmail statute.

\section{1. "Hard" bargains.}

Explicitly or implicitly, every potential commercial transaction conforms to the same double conditional form as does blackmail. The proposition implicitly conveyed by your local retailer, for example, is this: "If you pay me the listed purchase price for any good in my store, I will give it to you; if you do not, I won't." Aside from a formal structural similarity, this proposition does not look much like blackmail. Things get a little murkier, however, in the case of the "hard bargain," like that presented by Jeffrie Murphy's hypothetical owner of the Babe Ruth-autographed baseball. ${ }^{204}$ 
The hard bargainer is a seller who opportunistically jacks up his price when he encounters a would-be buyer with an unusually great need or desire for the seller's good. Consider an antique dealer possessed of a cheap and ugly vase that, despite her best efforts, she has been unable to unload for years. One day she receives a visit from an eccentric multimillionaire who announces that the vase is precisely what he needs to complete his collection and cap a lifelong search. When he asks the price, the dealer answers that she will not part with it for a penny less than $\$ 10$ million. The collector, not a complete fool, is flabbergasted. "But its not worth anywhere near that much!" he argues. "Very true," the dealer responds. "Indeed, just before you walked in, I was considering throwing it out to make space for other merchandise. But I know both that you want it and that you can afford my new price. Take it or leave it."

Whatever we might think of the dealer's behavior, we could not plausibly condemn it as criminal so long as we (rightly) refrain from imposing price controls or a ban on price discrimination in all its forms. Any satisfactory theory of blackmail must, therefore, coherently explain why the hard bargain is not blackmail. The evidentiary theory provides just such an explanation. It begins by considering the act threatened-in this case, to retain ownership of the vase. Very simply, this action could not be criminalized-no matter what an observer might infer about the motives of the actor-because it would not satisfy the harm requirement. Plainly, the collector has no legally protected interest in the vase; neither does the public at large (though we can imagine systems of property law under which it would). By withholding from the collector a benefit in which he has no legal interest, the dealer cannot inflict legally cognizable harm. Because the dealer's reasons for keeping the vase - or even for destroying it, were that her choice-are legally immaterial, a conditional threat to do either unless paid off cannot provide any legally relevant information. Therefore, the conditional threat should be as legal as the unconditional performance of the act. In terms of the evidentiary blackmail test, a "hard bargain" is not criminal blackmail because, under the second step from Section III.A, the acts threatened (to keep the vase or even to destroy it) would not inflict legal harm. ${ }^{205}$

\footnotetext{
${ }^{200}$ It is telling that the hard bargain "fails" the blackmail test at the second step, rather than the fourth. The hard bargainer may (at least in certain cases) act with motives we might wish to condemn as immoral, though we do not believe her conduct should be made criminal. Put another way, there is a reasonable sense in which our hypothetical millionaire collector might sputter with outrage, "But that's blackmail!" even though he
} 


\section{Market price blackmail.}

Imagine $B$ possesses an embarrassing photograph of celebrity $A$, for which a supermarket tabloid will pay $\$ 1,000$. Assume no external factors would make $B$ 's agreement to sell the photo a moral wrong (that is, for example, $B$ obtained the photo without committing an immoral act and has no prior duty of confidentiality to $A$ ). $B$ approaches $A$ with this proposition: "If you pay me $\$ 1,000$, I'll give you this photograph and its negative; if you do not, I'll sell them on the open market." Theorists are divided over whether this proposal - "market price blackmail" - should be lawful. ${ }^{206}$ This scholarly uncertainty is understandable. An evidentiary analysis reveals this to be one of the most complex riddles within the blackmail puzzle.

At first blush, this might appear an easy case. $B$ 's sale of damaging information about $A$ to tabloid $(T)$ would be no less hurtful to $A$ than if $B$ were to give the information to $T$ for free. Consequently, that $T$ would pay $B$ for the disclosure seems irrelevant. In both cases, $B$ would have morally acceptable motives for disclosing to $T$ only if she were to act for the purpose of achieving what she (reasonably) perceives to be a greater moral good. Her offer to refrain from disclosing the photographs to $T$ if paid by $A$ suggests that her disclosure would not be so motivated. The market price proposition to $A$ thus has the same evidentiary significance as it would in the absence of a market. Because $B$ 's offer to $A$ appears inconsistent with the assumption that $B$ believes publication would serve a public interest, the conditional proposition-at market price or otherwise-reveals the moral blameworthiness necessary for making such "blackmail" criminal.

This argument is sound so long as doubt about $B$ 's motives constitutes one sufficient reason not to criminalize $B$ 's sale to $T$ in the absence of a blackmail offer to $A$. Very likely, we would attribute public spirited motives to some such unconditional disclosures-

knows that the dealer's proposition is lawful and believes that it should remain so. See Greenbelt Cooperative Publishing Association, Inc v Bresler, 398 US 6, 14 (1970) (noting that accusing a hard bargainer of blackmail was neither slander when spoken nor libel when reported because the implication was so well understood that no one would have thought the bargainer was being accused of a crime).

${ }^{200}$ Compare Murphy, 63 Monist at 164-65 (cited in note 2) (proposing to decriminalize blackmail when the putative blackmailer seeks only the going market price); Ginsburg and Shechtman, $141 \mathrm{U}$ Pa L Rev at 1860 (cited in note 2) (same); Feinberg, Harmless Wrongdoing at 262-64 (cited in note 2) (deeming "[d]emands for fair compensation for considerate offers not to publish" instances of "[p]lausibly justified blackmail"), with Lindgren, $141 \mathrm{U} \mathrm{Pa} \mathrm{L} \mathrm{Rev} \mathrm{at} 1987$ (cited in note 3) (opining that market price blackmail "seems like classic blackmail" and concluding that, "[g]iven the lack of agreement over the rationale for blackmail," its continued criminalization is sound). 
principally those that reveal a wrongful act by, or character flaw of, some person in a position of public trust. In these cases, the market price blackmailer's conditional offer of silence has real evidentiary value. But most disclosures that might be leveraged into market price blackmail are probably not like this. It is more likely, I think, that the bulk of information sold "on the market" consists of things like photos of movie star $M$ in the nude, or the revelation that former basketball great $S$ is sleeping with a nineteen-year-old. And these sales are probably not motivated by the seller's belief that other morally compelling interests outweigh the harm caused $M$ or $S$. Instead, the seller's purpose is to make a buck-not a motivation that makes the harm-causing sale morally justifiable.

If this is so, the market price blackmail offer has little or no evidentiary value, in which case the evidentiary theory cannot distinguish between the threat and the act. And if the evidentiary theory cannot distinguish market price blackmail from market price public disclosures of information about celebrities-because the former is no more likely than the latter to be undertaken with bad motives-then one of two conclusions follows: either $B$ 's sale to $T$ should be made criminal, ${ }^{207}$ or it should not be, but only because other considerations favor its legalization notwithstanding that its criminalization would be justifiable under the third criterion. In fact, one strong reason for allowing $B$ to sell embarrassing information about public figures should jump immediately to mind: the First Amendment probably forbids government intervention in this type of information market. ${ }^{208}$ The likely upshot, therefore, is (1) $B$ should be permitted to sell $T$ reputationally

${ }^{207}$ See Murphy, 63 Monist at 165 (cited in note 2) (discussing the market price blackmail of public figures in the context of a market created by magazines such as the $\mathrm{Na}$ tional Enquirer and concluding that "[i]f one really wants to criminalize even this as blackmail, then it does seem to me that-in consistency-one ought also to seek the prohibition of the wider market").

${ }^{200}$ There is a separate possible explanation for why we might tolerate the disclosure notwithstanding the bad motives surmised. Insofar as public figures have elicited public interest-thus creating the market necessary to produce a market price-by voluntarily entering the realm of public attention, they have made their private lives, to some extent and in some indistinct sense, public commodities. It could be argued, therefore, that by seeking and achieving celebrity, public figures have assumed the risk of widespread invasions of their privacy. Arguably, then, any harm such invasions may cause should not be legally cognizable. See Feinberg, Harmless Wrongdoing at xxviii (cited in note 2) (defining "wrongless harms"). Notably, this argument for legalizing the disclosure also favors legalizing the market price blackmail, which turns out to be just like the hard economic bargain: because it does not matter for purposes of the criminal law whether one who sells reputationally harmful information about a celebrity to a publisher is motivated by her view of the public interest or just by narrow pecuniary gain, any potential evidentiary value of the market price blackmail proposition is legally irrelevant. 
harmful information about public figure $A$, even though (2) the class of persons who make the unconditional sale to $T$ are probably not less morally blameworthy than those who make a conditional offer to $A$.

Should any of this matter for purposes of deciding whether to prohibit market price blackmail? Maybe. ${ }^{209}$ Insofar as the third criterion of criminalization serves a retributivist general justifying aim, the reasons for tolerating (presumptively) morally blameworthy sales of harmful information to third parties are probably irrelevant to the criminalization of market price blackmail. Even if the average market price blackmailer is no more blameworthy (and very possibly less) ${ }^{210}$ than the average unconditional seller, all that matters is whether his conduct is ordinarily harm-causing and morally blameworthy. As we have seen, it appears that it is. That some other harm-causing blameworthy conduct (the sale of reputationally harmful information to $T$ ) remains legal is beside the point.

But to the extent the third criterion serves a consequentialist justifying aim, the argument for decriminalizing market price blackmail seems strong. After all, the market price blackmailer of $A$ differs from one who simply sells reputationally harmful information to $T$ in one conspicuous respect: he gives a right of first refusal to the person most likely to be harmed by publication of the information. This seems like a decent thing to do. Insofar as we adopt the third criterion of criminalization in order to reinforce desired moral norms, ${ }^{211}$ we risk disserving those norms by drawing criminal lines that prominently distinguish two categories of

${ }^{200}$ Even if they do not lead us to conclude that this conduct should be decriminalized, the foregoing assumptions might nonetheless advise against terming the conduct "blackmail." Indeed, if point (2) above is correct, the market price threat would not qualify as blackmail under my proposed definition, which specifies that the actor's motives for engaging in the threatened act would be opaque but for the conditional offer. See text accompanying note 183. Of course, we could keep the market price threat criminal, call it "blackmail," and revise my proposed definition. But to do so would risk undermining the threat's evidentiary significance-which is the key to unlocking the blackmail puzzle. Consequently, if this conduct is to remain criminal, conceptual precision might be better served by deeming it a form of extortion, and expanding that definition to include some threats to perform acts that, although legal, could be made criminal on familiar principles.

${ }^{210}$ One reason why so many people favor legalizing market price blackmail becomes clear by imagining what a market price blackmail proposition might look like: "I happen to have a photograph of you for which a tabloid is willing to pay $\$ 1,000$. Im inclined to take the money," $B$ begins, "however, I know that if I sell it, its publication will cause you some degree of discomfort. I have no desire to cause you harm. So Im willing to turn over the photo to you for the same $\$ 1,000$ the tabloid has offered." See, for example, Feinberg, Harmless Wrongdoing at 263-64 (cited in note 2) (describing the "fair compensation" blackmailer as "commendably benevolent," "thoughtful," "considerate," and "genero[us]").

${ }^{2 n}$ See note 144. 
conduct but discourage and punish the seemingly less blameworthy of the two. ${ }^{212}$ In short, then, the particular reasons for legalizing the unconditional sale by $B$ to $T$ should, on consequentialist reasoning, entail also legalizing the conditional sale offer by $B$ to $A^{213}$

\section{Crime exposure blackmail.}

A second special category within the central case is thought to arise when the information $B$ threatens to reveal would not merely embarrass $A$, but would subject him to criminal penalty. This variation, which we may inelegantly term "crime exposure blackmail," has provoked particular attention from law and economics scholars, who query whether permitting blackmail of this type would benefit society as a form of private law enforcement. Their answers vary. ${ }^{214}$

${ }^{212}$ Perhaps this anomaly would not send a perverse social message were there strong reasons for actually encouraging (rather then merely tolerating) $B$ 's sale to $T$. But this is probably not the case, for the First Amendment interests implicated (in the case of public figures who are not public officials) are more likely ones of process than outcome. That is, the health of a free society does not depend on whether we see photos of Fergie topless; it matters only that the government not decide whether we do.

${ }^{213}$ Legalizing market price blackmail need not entail legalizing "supra market price blackmail" - the offer to sell $A$ embarrassing information for a sum substantially in excess of what $T$ would pay (as in the recent Bill Cosby case). The state can regulate the price $B$ may charge $A$ for nonpublication-capping it at the market price-for the same reason the state engages in price regulation elsewhere. Price regulation is a common way of limiting the monopolist's price to a hypothetical competitive price. And the blackmailer (market price, supra-market price, or otherwise) must be a monopolist (or, at least, an oligopolist) of the information he threatens to reveal, else his offer of secrecy would have little value. However, $B$ 's possession of information about $A$ does not make him equally a monopolist with respect to the rest of the world as it does with respect to $A$ himself. If $B$ is the only person with photographs of $A$ in a compromising position, he is, by definition, a monopolist supplier. But his monopoly is economically meaningful only to the extent there are no adequate substitutes for those photos. In the broader market of "information about public figures," substitutes for $B$ 's photos of celebrity $A$ usually do exist-embarrassing or scandalous information (photographs, interviews, etc.) about celebrities $C, D$, and $E$. But these are not substitutes as far as $A$ is concerned. Consequently, consistent with wellestablished justifications for economic regulation of monopolies, the state could reasonably decide to protect $A$ from monopolistic exploitation by prohibiting $B$ from charging $A$ more than the hypothetical competitive price for the information in question-a price adequately approximated by the existing market price. Conceivably, the state could even enforce this rule through the criminal law on the strength of the first criterion of criminalization. See text accompanying note 142 .

${ }^{214}$ Compare, for example, Brown, $141 \mathrm{U} \mathrm{Pa} \mathrm{L}$ Rev at 1935 (cited in note 12) (arguing that legalizing blackmail of criminals would probably increase deterrence of other crimes), with Posner, $141 \mathrm{U} \mathrm{Pa} \mathrm{L} \mathrm{Rev} \mathrm{at} \mathrm{1823-27} \mathrm{(cited} \mathrm{in} \mathrm{note} \mathrm{2)} \mathrm{(concluding} \mathrm{that} \mathrm{the} \mathrm{effects} \mathrm{are}$ ambiguous); Landes and Posner, $4 \mathrm{~J}$ Legal Stud at $42-44$ (cited in note 39) (same); Shavell, $141 \mathrm{U} \mathrm{Pa} \mathrm{L} \mathrm{Rev} \mathrm{at} \mathrm{1899-1900} \mathrm{(cited} \mathrm{in} \mathrm{note} \mathrm{23)} \mathrm{(contending} \mathrm{that} \mathrm{it} \mathrm{is} \mathrm{more} \mathrm{efficient} \mathrm{to}$ maintain a ban on crime exposure blackmail, supplemented by public authority to offer rewards for the identification of criminals). 
Whatever uncertainty a utilitarian (or wealth maximization) analysis might engender, it is probably obvious to most people that crime exposure blackmail should be a crime. Indeed, under the reductivist approach of Feinberg and Gorr, the matter is simple: because it is wrongful to withhold information about a crime, it is equally wrongful to offer to withhold it for payment. ${ }^{215}$ Both the offer and the unconditional performance of the act offered may be criminalized. In fact, however, the criminal law treats the conditional offer substantially more severely. Under the common law, the mere failure to report information about a crime (including the identity of the perpetrator) was a misdemeanor called misprision of felony. ${ }^{216}$ Modern statutes have tended to ignore it entirely. ${ }^{217}$ In contrast, the conditional threat to report information about a crime is blackmail. ${ }^{218}$ The evidentiary theory-based on the insight that the blackmail proposition is important for what it tends to reveal about the reasons this particular actor would have for engaging in the act threatened-explains why.

The critical step is to explore why the law tolerates a failure to expose a criminal. Plainly, silence can cause substantial harm to the public. It hampers efforts to punish and deter crime, and it can be a but for cause of the criminal's future crimes. Moreover, the moral blameworthiness of remaining silent in this case also seems apparent, at least initially, for it tends to bespeak a disregard for the common good and the concrete interests of actual and potential victims. But a moment's reflection reveals that we should not quickly attribute bare selfishness to the silent witness. ${ }^{219}$ Her silence may be motivated largely by fear of retaliation, by friendship and loyalty toward the criminal, and by fear of the police. Our sympathy for these motivations provides an explanation for the lenient treatment. ${ }^{220}$

${ }^{215}$ See Feinberg, Harmless Wrongdoing at 243-45 (cited in note 2).

${ }^{218}$ See id at 243.

${ }^{217}$ See P.R. Glazebrook, How Long, Then, Is The Arm Of The Law To Be?, 25 Mod L Rev 301, $307 \mathrm{n} 51$ (1962) ("No court in the United States has been prepared to adopt the English doctrine in its simplicity, and hold that a mere failure to disclose knowledge of a felony is itself an offence."). However, through the offense of "compounding," the Model Penal Code would make it a misdemeanor to accept money in consideration for failing to report to law enforcement authorities information about the suspected commission of a crime. MPC \& 242.5.

${ }^{218} \mathrm{See}$, for example, MPC $\S 223.4(2)$ (defining as guilty of "theft by extortion" anyone who "purposely obtains property of another by threatening to . . . accuse anyone of a criminal offense").

${ }^{219}$ Here the term "witness" refers loosely to anyone who has knowledge relevant to the discovery of a crime or the capture and conviction of the culprit, no matter the nature of the information or the manner in which it was obtained.

${ }^{20}$ This seems to be the very sentiment underlying Chief Justice Marshall's famous pronouncement in Marbury v Brooks, 20 US (7 Wheat) 556, 575-76 (1822): "It may be the 
Consider now the threat. Had the witness threatened to expose the criminal unless paid off, we infer that her motives for violating her civic duty had nothing to do with either love or fear of the criminal (either of which would be a morally mitigating factor). Rather, we can infer, she was motivated by pure selfishness. The fact of her blackmail proposal provides circumstantial evidence as to her mental state: we now believe that she was in fact activated by more culpable motives than, absent this evidence, we had hypothesized might have motivated her.

The evidentiary test (when applied with slight variation) reaffirms this conclusion. The variation is to reverse the roles of threat and offer in the analysis. Assume, then, that the actor performed the act offered $(-y)$. The mere act of remaining silent is not a crime, or, if a crime, is a fairly trivial one (step 1). The act does, however, cause cognizable harm to the public (step 2). The effective legalization of the act is due to a surmise that the actor is motivated more by fear or loyalty than by selfishness (step 3). Consideration of the threat ("I'll tell unless you pay") strongly undermines this hypothesis. Therefore, crime exposure blackmail should be both a crime and a more serious offense than mere misprision of felony.

\section{Victim blackmail.}

Should the preceding analysis of crime exposure blackmail change if the individual who threatens to expose $A$ 's crime was $A$ 's victim? What if $B$ threatens to file a criminal complaint against $A$ unless $A$ provides $B$ reasonable compensation for the harms $B$ actually suffered? The Model Penal Code specifies that it should be an affirmative defense to a prosecution for threatening to "accuse anyone of a criminal offense ... that the property obtained by threat of accusation ... was honestly claimed as restitution or indemnification for harm done in the circumstances to which such accusation ... relates." ${ }^{221}$ This defense was added "in

duty of a citizen to accuse every offender, and to proclaim every offence which comes to his knowledge; but the law which would punish him in every case for not performing this duty is too harsh for man." The immediately preceding sentence provides revealing context for the otherwise cryptic qualifier in every case: "The only feature in the transaction to which blame is attached," the Court explained, "is the attempt of a father-in-law to conceal the forgeries of a son-in-law, by paying off the notes he had forged." See also Haupt $v$ United States, 330 US 631, 641-42 (1947) (holding in a treason prosecution that "[i]t was for the jury to weigh the evidence that the acts proceeded from parental solicitude against the evidence of adherence to the German cause" and that the jury could disbelieve defendant's contention that he "merely had the misfortune to sire a traitor and all he did was to act as an indulgent father toward a disloyal son").

${ }^{221}$ MPC \& 223.4. 
order to assure that one who had a civil complaint for damages against another could not be convicted of extortion for threatening during negotiations to file a criminal charge"-conduct "many regard as legitimate negotiating tactics. ${ }^{2222}$

Such a negotiating ploy would not be legitimate under an evidentiary analysis. ${ }^{223}$ The purpose of the criminal law is not principally compensatory. It serves retributive, deterrent, incapacitative, and rehabilitative goals that are not comparably well served by monetary (let alone confidential) settlement between offender and victim. Consequently, if we believe that all members of the community have a civic duty to report crime, then it cannot be morally acceptable for a victim to offer to ignore her obligation for personal gain-even if that gain is in some sense compensatory. This is not to claim it makes no moral difference whether $B$ is $A$ 's victim (rather than a mere witness to $A$ 's crime) and is demanding arguably "reasonable" compensation (rather than an excessive "penalty"). It is only to conclude that the difference is not such as to make $B$ 's conduct morally justified. The factors the Model Penal Code identifies can properly be considered mitigating; they should not constitute an affirmative defense.

In contrast to the criminal law, victim compensation is the chief purpose of tort law. The evidentiary test reinforces the intuition that $B$ may threaten to sue $A$ unless $A$ compensates $B$ for the injuries and losses that $A$ has caused to $B$. Assume $B$ files suit against $A$. This action is moral and lawful on the presumption (step 3) that $B$ is motivated by a good faith belief that he has a legally enforceable claim for damages against $A$. Now consider the fact that $B$ had offered not to sue if $A$ paid $B$ 's damages. This evidence is consistent with the motivation we previously ascribed to $B$ : either way, $B$ 's (morally acceptable) objective is to be made whole.

${ }^{220}$ Id at comment (f).

220 The ethical rules governing attorney conduct likewise reveal such action to be of questionable legitimacy. The 1969 Model Code of Professional Responsibility Disciplinary Rules provides that "[a] lawyer shall not present, participate in presenting, or threaten to present criminal charges solely to obtain an advantage in a civil matter." Model Code of Professional Responsibility and Code of Judicial Conduct DR 7-105A (ABA 1982). The 1983 Model Rules of Professional Conduct lack any such specific proscription. Instead, they generically bar criminal conduct "that reflects adversely on the lawyer's honesty, trustworthiness or fitness as a lawyer in other respects." Model Rules of Professional Conduct Rule 8.4(b) (ABA 1983). As a result, threatening to file a criminal complaint would constitute an ethical violation only in jurisdictions where it would violate the criminal law. 


\section{Public interest blackmail.}

The typical blackmailer demands from his victim a cash payment to which he has no legitimate claim. But the blackmailer need not demand money. Nor need he even seek private advantage (narrowly defined). A recurring question, accordingly, is whether blackmail should be criminalized when the blackmailer's ostensible objective is a public, rather than private, good. Under the evidentiary approach, the answer is clear: it depends.

We can solve the puzzle of "public interest blackmail" by examining what is presumed to be one of the most common blackmail threats, "homosexual blackmail."224 Assume $B$ threatens to expose $A$ 's homosexuality (or homosexual acts) unless $A$ pays $B$ $\$ 1,000$. This is an unproblematic case of criminal blackmail. And quick application of the evidentiary test explains why. The key (step 3 ) is to identify the morally justifying reasons $B$ might have for exposing $A$. Different observers will have widely differing intuitions regarding which reasons do in fact supply moral justification for outing $A$. Most persons, I suspect, would recognize few if any motives as morally legitimate beyond protecting a benighted spouse or suitor. Others might endorse a more general interest in exposing homosexuals, perhaps as a means to discourage homosexual activity. ${ }^{225} B$ 's conditional offer of silence (step 4) should have evidentiary significance to individuals who fall near either pole, however. $B$ 's willingness to remain silent for personal gain suggests that his motives for exposing $A$ would satisfy neither the social liberal nor the cultural conservative.

The public interest variant on homosexual blackmail arises when $B$ threatens to out $A$ unless $A$ takes some specified action favorable to homosexual interests. Imagine that a gay rights organization threatens to out a closeted gay Congressman unless he abandons his support for anti-gay legislation. ${ }^{226}$ Under an eviden-

${ }^{2 a}$ For evidence regarding the possibly great frequency of such threats, see Posner, 141 $\mathrm{U} \mathrm{Pa} L \mathrm{~L}$ Rev at $1843 \mathrm{n} 47$ (cited in note 2).

${ }^{225}$ Some people might conclude that outing is categorically unjustifiable. This view does not, however, undermine the evidentiary theory. One who believes there are no morally acceptable reasons for exposing an individual's homosexuality should, I submit, favor making outing illegal (on the second or third criteria of criminalization). They can then approve criminalizing homosexual blackmail on the grounds that it is (or should be) simple extortion.

${ }^{208}$ In the summer of 1996, the Advocate, a gay-oriented national magazine, threatened to out Arizona Congressman James Kolbe because of his support for the Defense of Marriage Act, which provides that states need not recognize same-sex marriages performed in another state. Kolbe preempted the Advocate by announcing his homosexuality in advance of the magazine. See John E. Yang, Rep. Kolbe Announces He Is Gay, Wash Post A8 (Aug $3,1996)$. 
tiary analysis, this proposal should be legal because the threat provides little support for an inference that, were the threateners to expose the legislator, they would do so with blameworthy motives. Again, the third and fourth steps of the evidentiary test explain this conclusion. Were the gay rights activists to out the Congressman, their likely motivation would be to expose the latter as a (probable) hypocrite and political opportunist. ${ }^{227}$ The activists' offer to keep the legislator's homosexuality secret if he supports gay political interests is potentially consistent with this hypothesis: the activists' (arguably) morally acceptable reason for outing the legislator disappears if the basis upon which voters might suspect the legislator of hypocrisy is eliminated. This does not mean, however, that all blackmail putatively in the public interest should be permissible. If members of Greenpeace were to threaten to out the same closeted Congressman unless he were to vote against NAFTA, then the blackmailers' belief that they are furthering the public interest should be legally irrelevant. The particular content of their offer tends to discredit, rather than confirm, the supposition that they harbor morally acceptable motives for exposing the politician's homosexuality.

This discussion reveals that Feinberg is only half right in admonishing that a coherent blackmail theory must survey "the various types of threats in addition to threats to reveal information; ... the various types of demands in addition to demands for money or property; and ... the various types of means employed in addition to single-shot random opportunism." mands, and means all matter. But they must not be assessed in isolation. The lesson of public interest blackmail is that a threatener should not be entitled to escape a criminal prohibition on blackmail just because he seeks to achieve what he might reasonably believe is a public interest, rather than his own (narrow) self-interest. This is appropriate: a modern-day Robin Hood would have no defense to charges of burglary or robbery, and few would criticize this result. Where the act threatened, $y$, and the condition demanded, $x$, would serve the same public interest,

${ }^{27}$ This was precisely the rationale espoused by the Advocate in the Kolbe case. See id. This is not to say the suspicion is correct. A homosexual politician can oppose a piece of (ostensibly) gay-friendly legislation without being hypocritical, just as an AfricanAmerican politician can with integrity oppose legislation considered to benefit AfricanAmericans as a whole or a Jewish politician can oppose policies favorable to Israel. Indeed, Barney Frank, an openly gay Congressman from Massachusetts, declared that he approves of outing "in cases of gross hypocrisy," but did not think Kolbe's was such a case. See Kolbe Won't Be Gay Rights "Poster Boy", Worcester Telegram \& Gaz A10 (Aug 4, 1996).

Feinberg, Harmless Wrongdoing at 258 (cited in note 2). 
however, the conditional proposition would properly be excepted from a blackmail ban.

\section{Noninformational blackmail.}

Blackmail does not invariably involve a threat to disclose information. While cases of noninformational blackmail may be unusual, they are not difficult to imagine. Professor Leo Katz has composed a variety of examples:

"Pay me $\$ 10,000$, or I will seduce your fiancé"; "Pay me $\$ 10,000$, or I will persuade your son that it is his patriotic duty to volunteer for combat in Vietnam"; "Pay me $\$ 10,000$, or I will give your high-spirited, risk-addicted 19-year-old daughter a motorcycle for Christmas"; "Pay me $\$ 10,000$, or I will hasten our ailing father's death by leaving the Catholic Church. ${ }^{229}$

As the evidentiary theory explains, all of these threats are clear cases of criminal blackmail.

The acts threatened in noninformational blackmail, as in all blackmail, are perfectly legal. But they also cause (or risk) cognizable harm. Indeed, three of the four examples above involve imposing substantial risk of death upon another. Nonetheless, the acts themselves are tolerated, perhaps encouraged, because we assume that the people who commit them have good reasons to risk harm. The ordinary assumption, for example, is that when $B$ encourages $A$ to enlist, she does so because she believes that it is $A$ 's duty or that $A$ will profit from the experience. Here, as elsewhere, the conditional threat has evidentiary significance: $B$ 's offer not to encourage $A$ to enlist if $B$ receives a suitable boon seems inconsistent with our initial assumption. The offer reveals $B$ 's willingness to risk $A$ 's death, and not for good motives. Hence, the threat should be made criminal.

While the evidentiary theory supports Katz's view that blackmail need not be a crime of information, ${ }^{230}$ Katz's examples

${ }^{229}$ Katz, $141 \mathrm{U} \mathrm{Pa} \mathrm{L}$ Rev at 1567-68 (cited in note 92).

${ }^{200}$ Not everything that looks like noninformational blackmail should be treated as such. Nozick, among others, has drawn attention to a deceptively tricky case: $B$ 's threat to build a structure on his land that will block the view of his neighbor $A$, unless $A$ pays $B$ $\$ 1,000$. Nozick, Anarchy, State, and Utopia at 84-85 (cited in note 2). Consistent with the evidentiary theory, $B$ 's proposal should be criminal (assuming, counterfactually, that blocking $A$ 's view is a legally cognizable harm) only if the offer has substantial probative weight toward demonstrating that $B$ would have no actual, legitimate interest in building the structure. But does it? Is it not just as likely that $B$ values the structure, but at somewhat less than $\$ 1,000$ ? And why are such structures often called "spite fences" (at least when they are, indeed, fences)? Doesn't this nomenclature suggest that, in this category of 
likewise support the claim of the evidentiary theory that the threat has evidentiary value only. Imagine this variation on Katz's last hypothetical: $B$ leaves the Catholic Church; $B$ 's father dies; $B$ returns to the Catholic Church. Add a few more facts-a long history of animosity between $B$ and her father, or a substantial inheritance-and the inference that $B$ left the Church precisely in order to hasten her father's death is easy to make. If so, $B$ 's actions might suddenly look like a rare (but potentially effective) method of homicide-murder by religious conversion. At the same time, the blackmail threat would no longer look like a morally aggravating factor. ${ }^{231}$

\section{Bribery.}

A final puzzle is what Professor Sidney DeLong calls the second paradox of blackmail: why is a conditional offer that would be illegal if proposed by the blackmailer legal if initiated by the victim? ${ }^{232}$ DeLong locates the moral difference between blackmail and "bribery" (a proposal initiated by a potential blackmail victim) in the social meaning of the narratives paradigmatic of the respective transactions. "[T] DeLong proposes in a vein similar to Fletcher's, "is to protect the community against the conspiratorial agreement of blackmailer and victim, which isolates and subjects him to a submissive relationship with the blackmailer." ${ }^{3233}$ In contrast, "[t]hrough bribery, the victim transforms the menace into an ally whose cooperation preserves the victim's place in the larger community. ${ }^{.234}$

No doubt this explanation touches on one distinction between blackmail and bribery. But it does not cut as forcefully as DeLong suggests. After all, the briber risks highlighting his vulnerability to disclosure, thereby increasing the risk that the recipient of his bribe will return for more-next time as a blackmailer. In any event, the "puzzle" DeLong seeks to solve is not very puzzling. Bribery is legal because, ordinarily, there is not the slightest basis for criminalizing it.

cases, the probability that $B$ would make a conditional offer if acting from bad motives is actually less than if acting from good motives-thereby denying the evidentiary inference? See note 179 and text accompanying note 175.

${ }^{231}$ This conclusion should not sound bizarre. Recall the robber who says, "Your money or your life" to induce his victim to hand over her money, and compare him to the man who approaches a stranger on the street, pulls a gun, declares, "Your life," and shoots him dead. The robber can only be convicted of robbery, the murderer of murder.

${ }^{222}$ DeLong, $141 \mathrm{U} \mathrm{Pa}$ L Rev at 1663 (cited in note 11).

${ }^{23}$ Id at 1691.

24 Id at 1692. 
When the act the briber solicits is itself clearly wrongful, there is nothing perplexing about making the bribe illegal and punishing both the giver and the receiver-hence the common law crimes of "bribery" (offering a government official payment for favorable treatment) and "extortion under color of public office" (solicitation or acceptance by a public official of payment). ${ }^{235}$ Similarly, the Model Penal Code makes it separately criminal both to offer to pay a witness to a crime to remain silent and for the witness to accept such a payment. ${ }^{236}$ Accordingly, the supposed puzzle of bribery arises only when the moral character of the act the briber solicits is indeterminate-as when $A$ offers $B$ $\$ 1,000$ for $B$ 's promise not to tell $A$ 's wife about $A$ 's extramarital affair, or not to give a motorcycle to $A$ 's risk-addicted daughter.

In these cases, the so-called bribe is legal, and should remain so, because it satisfies neither fundamental prerequisite for criminalization (under the third criterion, at least). It inflicts no legally cognizable harm, and it reveals no morally blameworthy motives. The briber's motivation in each case is quite apparent, and is no different from that of the driver who parks his car in a rough neighborhood and offers to pay some guys loitering nearby to "keep an eye on it." Blackmail is criminal, according to the evidentiary theory, because the blackmailer threatens an act that, were he to engage in it, would be blameworthy, harm-causing conduct. Bribery, on the other hand, is lawful because the briber seeks to stave off potential harm (to himself or to someone else) and because he may well have morally acceptable motives.

All that seems straightforward. The more difficult question is whether it should be criminal to accept the bribe. If the nominal bribe really is just a payoff by a blackmail victim to a blackmailer savvy enough to convey his threat by innuendo, there is no reason why the law must respect the formal structure of the transaction; so long as a factfinder concludes that the nominal bribe taker intended to communicate a blackmail threat, it is reasonable to treat him as a blackmailer and to punish him accordingly.

But what if the idea of the bribe really did originate with the maker? Here, the evidentiary analysis requires us to examine two questions: (1) does the bribe taker cause legally cognizable harm? and (2) if so, does he have morally blameworthy motives? Receipt of bribes (outside of the special cases noted above) is, and should

\footnotetext{
${ }^{235}$ See James Lindgren, The Theory, History, and Practice of the Bribery-Extortion Distinction, 141 U Pa L Rev 1695, 1698-1700 (1993). See also MPC § 240.1.

${ }^{206}$ See MPC §§ 242.3, 242.5.
} 
remain, lawful on an evidentiary approach because the answer to both questions is (ordinarily) no.

Consider an earlier example: $B$ accepts $A$ 's offer of $\$ 1,000$ in exchange for a promise not to tell $A$ 's wife of his infidelity. Disregarding the payment, and ignoring causation complications suggested by the act/omission distinction, we might agree that $B$ "causes" $A$ 's wife to (continue to) be deceived as to her husband's faithfulness. This is probably not legally cognizable harm. Even if it were, we would be compelled to examine $B$ 's motives. Why might $B$ refrain from speaking out? Morally blameworthy motives are imaginable-perhaps $B$ takes pleasure in the knowledge that $A$ 's wife has been made an object of ridicule in the communitybut seem unlikely. Most probably, $B$ acts out of a habitual disinclination "to get involved." If pressed to explain himself, though, he would probably first invoke a general presumption that one should not undertake to "do good" unless one can be reasonably confident that one's intervention will produce more good than harm, then observe that he remains ignorant of too many potentially relevant factors to justify intermeddling. He might wonder, "Isn't it possible that unmasking $A$ as an adulterer would serve principally to cause $A$ 's wife substantial and unnecessary mental anguish?" This seems a wholly moral motivation for $B$ 's inaction: first, do no harm.

Not much changes once we consider $B$ 's acceptance of the payoff from $A$. It is still likely that $B$ believes intermeddling is unjustified. He might also believe that $A$ is a cad (or worse). $B$ 's willingness to profit at $A$ 's expense does not make it substantially less likely that $B$ would have remained silent even absent a payment, and that in either case (paid or not paid) his silence is principally animated by a concern that he not cause harm. One might propose, though, that $B$ is now causing harm to $A$ (rather than $A$ 's wife), and that he does so with morally blameworthy motives. But it is hard to see how $B$, by accepting a payment $A$ voluntarily made, is causing $A$ a "harm" with which the law should be concerned. ${ }^{237}$ In short, one who refrains from the type of action a bribe maker might wish to forestall is not likely enough to have (in)acted with morally blameworthy motives as to justify criminal punishment in accord with the third criterion. This is true

${ }^{207}$ It is fair to call $A$ 's payment "voluntary" in these circumstances. True, $A$ would rather $B$ did not know about his affair (in which case there would be no reason at all for him to pay $B$ ), but this fact alone cannot suffice to make $A$ 's offer "involuntary" without making the concept of "voluntary" action all but meaningless. Recall that if $A$ 's offer is in response to $B$ 's hinted threat of disclosure, $A$ 's offer is not voluntary, and $B$ is properly treated as a blackmailer. 
whether or not $B$ has been offered, and has accepted, payment for forbearance. ${ }^{238}$

\section{IMPLICATIONS}

Blackmail is a serious crime. Moreover, it exerts a grasp on the popular imagination almost surely out of proportion to its frequency. For these reasons alone, seeking to explain and justify its criminalization would be a worthwhile endeavor. But there is more, for those bitten by the blackmail bug have long suspected that a solution to the blackmail puzzle would help to resolve other puzzles both within and beyond the criminal law. ${ }^{239}$ This Section explores that suspicion by offering a few preliminary thoughts regarding the evidentiary theory's possible implications.

\section{A. Motive and Mens Rea in the Criminal Law}

At first blush, the evidentiary theory might seem to suggest an answer to arguably the most profound and persistent problem plaguing criminal theory-the "true" meaning of mens rea. ${ }^{240} \mathrm{Al}$ though Professor Francis Sayre concluded in his pathbreaking

\footnotetext{
${ }^{23}$ This is a general claim. There may be contexts in which the bribe taker's inaction does cause legally cognizable harm and in which the fact of the bribe provides sufficiently strong circumstantial evidence that the bribe taker's motives for inaction are morally blameworthy in order to justify criminalization. For example: $A$ harms $C$ by publishing a defamatory falsehood. $B$ is in possession of information that disproves the defamatory utterance. It is plausible that $B$ 's failure to disclose that information "causes" $C$ legally cognizable harm. Nonetheless, uncertainty about $B$ 's reasons for remaining silent might be great enough to counsel against making $B$ 's silence criminal. Naturally, $B$ 's silence would be morally justifiable were he ignorant of the fact of the defamation, or of the exonerating character of the information in his own possession. $B$ 's fear of retaliation by $A$ might also make it morally excusable for $B$ to remain mute. All of these hypotheses, however, are strongly undermined by the fact of $B$ 's acceptance of a payoff to remain silent. Here, $B$ 's bribe taking does suggest selfish motives for engaging in knowing harm-causing conduct. Consistent with the evidentiary analysis, then, this particular type of bribe taking-the proverbial exception that proves the rule-could be made criminal.

${ }^{209}$ In the (admittedly partisan) estimation of Katz and Lindgren, "one cannot think about coercion, contracts, consent, robbery, rape, unconstitutional conditions, nuclear deterrence, assumption of risk, the greater-includes-the-lesser arguments, plea bargains, settlements, sexual harassment, insider trading, bribery, domination, secrecy, privacy, law enforcement, utilitarianism and deontology without being tripped up repeatedly by the paradox of blackmail." Leo Katz and James Lindgren, Instead of a Preface, $141 \mathrm{U} \mathrm{Pa} \mathrm{L}$ Rev 1565, 1565 (1993).

${ }^{240}$ See generally Martin R. Gardner, The Mens Rea Enigma: Observations on the Role of Motive in the Criminal Law Past and Present, 1993 Utah L Rev 635. See also id at 637 \& $n 5$ (claiming that "few conceptual pursuits in any area of the law have proven so beguiling as the attempt to give an accurate account of the so-called mental element required for criminal liability"); Francis Bowes Sayre, Mens Rea, 45 Harv L Rev 974, 974 (1932) ("No problem of criminal law is of more fundamental importance or has proved more baffling through the centuries than the determination of the precise mental element or mens rea necessary for crime.").
} 
early study that the term embraced a wide multiplicity of meanings, ${ }^{241}$ it has become common, at least since the American Law Institute completed its Model Penal Code over a generation ago, to distinguish between two fundamentally different conceptions. As Professor Martin Gardner succinctly put it in his exhaustive recent study:

The first and historically original concept embodied an explicitly normative requirement that the offender not only intentionally commit a criminal act, but also do so out of evil motivation. The second and currently more predominant tradition adopts an essentially nonnormative approach that finds sufficient ground for liability in the presence of particular states of mind without evaluating or even appealing to the motives underlying the offender's actions. ${ }^{242}$

Plainly, the classical conception of mens rea-which Sayre equates with "little more than a general immorality of motive ${ }^{9243}$-closely approximates, or even mirrors, the notion of moral blameworthiness that underpins the evidentiary theory. Accordingly, insofar as the evidentiary theory's utility in solving the blackmail puzzle amounts to a powerful pragmatic vote in support of my third criterion of criminalization, it might weigh equally heavily in favor of the classical understanding of mens rea. This would be of more than theoretical interest. It is a commonplace assertion that there can be no crime absent the coincidence of actus reus and mens rea. ${ }^{244}$ If mens rea "really" requires moral blameworthiness, tangible consequences must follow-such

${ }^{241}$ See Sayre, 45 Harv L Rev at 1026 (cited in note 240) (concluding that "[t]he old conception of mens rea must be discarded, and in its place must be substituted the new conception of mentes reae").

${ }^{212}$ Gardner, 1993 Utah L Rev at 640 (cited in note 240 ).

${ }^{243}$ Francis Bowes Sayre, The Present Signification of Mens Rea in the Criminal Law, in Roscoe Pound, ed, Harvard Legal Essays 399, 411-12 (Harvard 1934). See also United States $v$ Thomas, 459 F2d 1172, 1176-77 (DC Cir 1972) (discussing the necessity of a requirement "beyond a mere intentional . . . act, one involving evil intent or a bad purpose" in jury instructions); Mullen $v$ United States, 263 F2d 275, 276 (DC Cir 1959) (defining mens rea as "evil state of mind"); Sayre, 45 Harv L Rev at 1019 (cited in note 240) (observing that as late as the mid-nineteenth century, "the conception of mens rea was based largely on moral blameworthiness"). For an argument that Sayre overstates the significance of motive in the early conceptions, see Hall, General Principles at 138-49 (cited in note 150).

${ }^{2 \mu}$ Consider the oft-quoted maxim frequently traced to Coke, actus non facit reum, nisi mens sit rea. See Edward Coke, The Third Part of the Institutes of the Laws of England *107 (1641). The translation is "an act does not make [the doer of it] guilty, unless the mind be guilty; that is, unless the intention be criminal." Black's Law Dictionary 36 (West 6th ed 1990). 
as abolition of strict liability crimes and recognition of an ignorance of law defense for all mala prohibita crimes. ${ }^{245}$

On reflection, though, it is doubtful whether the evidentiary theory alone has anything of importance to say about mens rea. The evidentiary theory appears to demonstrate that the fact that particular conduct ordinarily causes harm and reflects moral blameworthiness constitutes a prima facie justification for criminalization. However, it does not demonstrate that the coincidence of these conditions is necessary for particular conduct to be criminalized. More likely, all three criteria are valid bases for criminalization. Moreover, even when criminalization of conduct is justified on the strength of the third criterion alone, moral blameworthiness is still not necessarily required to justify imposing punishment in a given case. To be sure, if the third criterion rests on a retributivist general justifying aim, then no individual should be punished unless he is morally blameworthy for his offense. As H.L.A. Hart noted, retributivism in general justifying aim entails retributivism in distribution. ${ }^{246}$ But it is not certain that the third criterion does rest on a retributivist foundation. While a retributivist justifying aim would almost certainly yield the third criterion or something very much like it, so might a consequentialist justifying aim. ${ }^{247}$ And if criminalizing (ordinarily) blameworthy, harm-causing conduct is justified on consequentialist grounds, then the propriety of punishing one who violates the resulting criminal prohibition but is not morally blameworthy himself must remain an open question, dependent more upon contestable empirical assumptions than on logical deduction.

It seems, in short, that caution is warranted when assessing the significance of the evidentiary theory for criminal law in general. The instant solution to the blackmail puzzle (if correct) might entail the classical conception of mens rea, but it might not.

This is not the end of the matter, however, for at least one implication of the evidentiary theory is clear. Contrary to the familiar contention that "motive is immaterial in the substantive criminal law," ${ }^{248}$ motive has substantial relevance. First, as the equally familiar objection to this contention observes, the motives of an individual defendant can prove critical for the satisfaction of

${ }^{245}$ For a thoughtful discussion of the implications of the classical conception, see H.L.A. Hart, 23 Law \& Contemp Prob at 412-27 (cited in note 142).

${ }^{248}$ H.L.A. Hart, Punishment and Responsibility at 9 (cited in note 134). See note 142.

${ }^{277}$ See note 144.

${ }^{24}$ Wayne R. LaFave and Austin W. Scott, Jr., Criminal Law 227 (West 2d ed 1986). 
various affirmative defenses or for purposes of sentencing. ${ }^{249}$ Moreover, as the evidentiary theory reveals, the criminal law does seem to care-at least sometimes-about the motives of the class of potential defendants as a whole. Previous efforts to resolve the blackmail puzzle reflect one or the other of the customarily competing justifications for the state to criminalize conduct-that the conduct reduce utility (or its rough proxy, wealth), or that it be inherently wrongful. The conspicuous lesson of the evidentiary theory is to focus not on consequences, nor on acts, but on actors (at least at the stage of offense definition, if not necessarily when assessing liability). If criminal law theorists take this simple lesson seriously, I believe, the instant proposed solution to the blackmail puzzle will indeed facilitate a deeper understanding of the criminal law and might resolve a variety of seemingly intractable puzzles.

\section{B. Governmental Motives: Understanding Unconstitutional Conditions}

One concrete example of the evidentiary theory's potential relevance, outside the criminal law, is provided by the so-called unconstitutional conditions doctrine -that is, the question of when it should be unconstitutional for a government to condition a benefit it is not compelled to provide on the recipient relinquishing a constitutional right. Although governments attempt this maneuver frequently and in many contexts, courts have yet to provide clear rules for when the principle that a state may not do indirectly what it is prohibited from doing directly should trump the principle that the greater power (to withhold the benefit entirely) includes the lesser power (to grant it on condition). Enormous scholarly commentary on the subject has not clarified matters. ${ }^{250}$ While scholars widely agree that the conditional ten-

${ }^{219}$ The traditional view regarding motive is challenged in Douglas N. Husak, Motive and Criminal Liability, 8 Crim Just Ethics 3 (Winter/Spring 1989) (noting the familiar qualifications regarding the role of motive in sentencing decisions and the significance of specific intent crimes, and arguing that an actor's motives are also central to the criminal law's treatment of euthanasia, justification, and some excuses). Although a valuable contribution in its own right, Husak's essay is better read to initiate a debate than to offer a well-developed competing vision of the role of motive in the criminal law. Unfortunately, Husak's conclusion that "much important work . . . remains to be done" respecting "the significance of motives to criminal liability," id at 12 , is as apt now as it was nearly a decade ago.

${ }^{250}$ Among the most illuminating contributions are Sullivan, 102 Harv L Rev 1413 (cited in note 130); Richard A. Epstein, Foreword: Unconstitutional Conditions, State Power, and the Limits of Consent, 102 Harv L Rev 4 (1988); Seth F. Kreimer, Allocational Sanctions: The Problem of Negative Rights in a Positive State, $132 \mathrm{U} \mathrm{Pa} \mathrm{L} \mathrm{Rev} 1293$ (1984); William Van Alstyne, The Demise of the Right-Privilege Distinction in Constitu- 
der of governmental benefits should sometimes be held legitimate and sometimes unconstitutional, there is almost universal disagreement over where and why to draw the line.

The evidentiary theory of blackmail suggests an obvious answer: motive matters. Although it is sometimes said that the motives behind state action are constitutionally irrelevant, ${ }^{251}$ that is a demonstrable misstatement of existing constitutional doctrine. ${ }^{252}$ In several disparate areas of the law, a "bad" governmental motive will prove per se fatal to state action. ${ }^{253}$ In various other contexts, a bad motive will provoke strict scrutiny. ${ }^{254}$

When a constitutional violation (or level of scrutiny) turns on governmental motive, the plaintiff shoulders the burden of proving that it was illegitimate. In theory, this difficult task can be accomplished in several ways. ${ }^{255}$ Assume, for example, a nontenured public school teacher is fired, and that the teacher suspects

tional Law, 81 Harv L Rev 1439 (1968); Robert L. Hale, Unconstitutional Conditions and Constitutional Rights, 35 Colum L Rev 321 (1935).

${ }^{231}$ See, for example, United States v O'Brien, 391 US 367, 383-84 (1968); Alexander M. Bickel, The Least Dangerous Branch: The Supreme Court at the Bar of Politics 208 (Yale 1962).

${ }^{252}$ For a recent thoughtful rumination on the relevance of motive in public and private contexts, see Laurence H. Tribe, The Mystery of Motive, Private and Public: Some Notes Inspired by the Problems of Hate Crime and Animal Sacrifice, 1993 S Ct Rev 1. The classic arguments regarding the proper significance, for constitutional law, of state actors' motivations are Paul Brest, Palmer v Thompson: An Approach to the Problem of Unconstitutional Legislative Motive, 1971 S Ct Rev 95; John Hart Ely, Legislative and Administrative Motivation in Constitutional Law, 79 Yale L J 1205 (1970).

${ }^{235}$ For example, governmental action motivated to disadvantage a protected class will violate the Equal Protection Clause. See Personnel Administrator of Massachusetts $v$ Feeney, 442 US 256, 279 (1979). Action motivated to advance religion violates the Establishment Clause. See Stone v Graham, 449 US 39, 40-41 (1980). Similarly, action by any of the several states runs afoul of the Dormant Commerce Clause if undertaken for protectionist purposes. See Baldwin v GAF Seelig, Inc, 294 US 511, 522 (1935). And civil incarceration animated by a punitive purpose might violate constitutional protections against double jeopardy and ex post facto laws. See Kansas v Hendricks, 117 S Ct 2072, 2090 (1997) (Breyer dissenting) (noting that although the majority found that Kansas's civil commitment law was not punitive, "[t]he majority agrees that the [Ex Post Facto] Clause (forbids the application of any new punitive measure to a crime already consummated"), quoting California Deptartment of Corrections v Morales, 514 US 499, 505 (1995).

${ }^{25}$ Under rapidly changing voting rights jurisprudence, for example, the courts apply strict scrutiny to redistricting decisions when the linedrawers appear to have "subordinated" other, legitimate districting principles to race. See Bush v Vera, 116 S Ct 1941, 1951 (1996). See also id at 1972-73 (Thomas concurring) (arguing that strict scrutiny should apply whenever redistricters consider race). Likewise, under ordinary First Amendment doctrine, facially neutral laws are subjected to strict scrutiny if adopted for the purpose of favoring or disfavoring speech of a particular content. See Turner Broadcasting System v FCC, 512 US 622, 641-42, 645-46 (1994); Harry T. Edwards and Mitchell N. Berman, Regulating Violence on Television, 89 Nw U L Rev 1487, 1512-13 (1995) (discussing this aspect of Turner).

${ }^{2 s s}$ See Village of Arlington Heights $v$ Metro Housing Development Corp, 429 US 252, 265-68 (1977). 
she was terminated because of the school board's hostility to her communist sympathies. It is well settled both that her termination would violate the First Amendment if it were so motivated and that the burden rests on the teacher to establish that motivation. ${ }^{256}$ The teacher could satisfy her burden (thus shifting to the school the burden to demonstrate that it would have fired the teacher notwithstanding her political leanings) in numerous ways. She could hope to rely on statistical evidence of firings by the school board of other communist teachers that shows a dramatic correlation between a teacher's politics and her job history. Or she could introduce minutes from a school board meeting in which board members expressed hostility to her because of her political views. Alternatively or additionally, she could testify that her school principal offered to renew her contract, but only if she resigned her position on the board of the American Communist Party. This example suggests that a governmental condition is just another piece of circumstantial evidence that might help establish motive in a given case.

Accordingly, an evidentiary analysis might resolve the unconstitutional conditions doctrine as follows: if and only if the particular condition ("resign from position in communist organization") appears sufficiently inconsistent with any of the permissible reasons the state might have for withholding the benefit at issue (that the teacher's job performance was unsatisfactory, or that the school was eliminating the teacher's position for budgetary or curricular reasons), then the fact of the offer supports a presumption that the state's (but-for) motive for withholding the gratuitous benefit was improper, ${ }^{257}$ in which event the court is required either to hold the state action invalid per se or to subject it to the appropriate level of heightened scrutiny. Indeed, this solution closely approximates that advanced over sixty years ago by

\footnotetext{
${ }^{2 s 6}$ See, for example, Mt. Healthy City School District v Doyle, 429 US 274, 287 (1977); Perry $v$ Sindermann, 408 US 593, 598 (1972).

${ }^{287} \mathrm{As}$ in the blackmail context, the inference is not ironclad. In the termination case, the state could argue that it terminated the teacher solely because of her poor job performance. It could then try to explain away the conditional offer of continued employment by arguing, say, that the teacher was ill-prepared for class and chronically overtired, that the school board suspected these problems were due to the fact that she devoted many hours each day to her officership in the Communist party, and that, because she showed promise as a teacher, the board was willing to give her a second chance if they could have adequate confidence that she would devote sufficient time to her teaching duties. Of course, a comparable argument intended to rebut the inference of bad motive is not open to the ordinary defendant in a blackmail prosecution. Whether it should be available to the government in an unconstitutional conditions case depends upon whether the inquiry into motives is made ex post and particularistic or (as in the blackmail situation) ex ante and categorical-a question beyond the scope of the present discussion.
} 
Professor Robert Hale. ${ }^{258}$ Unfortunately, though, subsequent commentators have either overlooked or misunderstood Hale's analysis. ${ }^{259}$ The evidentiary theory suggests that attention to Hale's thesis might prove profitable if we can articulate more precisely than Hale did how the notions of "germaneness" and "impermissible motive" can do real work. Because the governmental proposal involved in cases in which the doctrine might apply shares the double conditional form of all blackmail propositions (if $x$ then $-y$; if $-x$ then $y$ ), the evidentiary test will be of promising utility in resolving the mystery of unconstitutional conditions.

\section{CONCLUSION}

It is a safe bet that blackmail's criminalization does not appear puzzling to the casual observer. Not only does it resemble

${ }^{258} \mathrm{Hale}$ begins by insisting that "there is no logical incongruity in holding that the validity of a state's exercise of power may depend upon the purpose for which it is exerted; that a power which is valid when exerted for most purposes may be invalid when exerted for others." Hale, 35 Colum $L$ Rev at 322 (cited in note 250). After examining a host of unconstitutional conditions cases, he opines that, when "determining the validity of a conditional burden," the Supreme Court would likely be influenced "by its views as to whether or not the condition is germane to the purpose for which the government might normally impose the burden, without conditions." Id at 352.

${ }^{259}$ The most thorough critique of Hale's argument comes from Sullivan. Her analysis proceeds in three steps. First, she demonstrates persuasively that heightened scrutiny is not invariably appropriate whenever government attaches a condition to a gratuitous benefit that is not germane to the legitimate purposes the government might have for withholding the benefit categorically and unconditionally. See Sullivan, $102 \mathrm{Harv}$ L Rev at $1461 \mathrm{n} 196$ (cited in note 130). Second, she asserts that because germaneness per se is not dispositive, "[s]ome theory of appropriate legislative process would seem necessary to explain" attention to the "germaneness" of governmental conditions. Id at 1468. Third, she canvasses the three principal contending theories of legislative process-interest group pluralism, civic republicanism, and public choice-en route to arguing that each either fails to explain any concern with germaneness of conditions and benefits or reflects too tenuous a relationship to unconstitutional conditions problems to be useful. Id at 1468-76. The upshot is that "germaneness theories fail to resolve unconstitutional conditions problems." Id at 1476.

Sullivan's analysis suffers from two defects. First, it rests on an ungenerous reading of Hale. Although Hale could no doubt have been clearer, he is better understood, I think, to recognize that it is illegitimacy of governmental purpose, not nongermaneness between condition and benefit per se, that raises constitutional problems. Lack of germaneness is significant only insofar as it often allows courts to infer that the legislature was motivated by illegitimate purposes. Second, even if this were not Hale's view, it is one that deserved consideration. As noted above, see notes 250-59 and accompanying text, existing constitutional doctrine identifies some governmental motives as substantively illegitimate (absolutely or presumptively) without itself resting upon any particular model of normative governmental process. Sullivan's critique of Hale is infirm because it never gives adequate attention to the theory that some governmental motives are simply illegitimate (no matter the legislative process that effectuates them), and that nongermane conditions are useful-though not dispositive-tools for identifying when such improper motives were at work. 
other varieties of theft, the criminalization of which rarely raises eyebrows, but blackmail just smells likes a nasty practice. Theorists from a wide range of disciplines, however, have long identified a puzzle-that it is illegal to threaten what it is legal to doand have worked vigorously to propose solutions.

Those solutions have been of two broad types. Some scholars, including many of a law and economics bent, have proposed that toleration of blackmail would produce a variety of adverse social consequences not arising in a regime that permits the acts a blackmailer threatens. Other writers, more deontologically inclined, have argued that the blackmail threat is inherently wrongful in a way that the acts threatened are not. But all extant theories suffer from serious failings. Blackmail does not always produce the consequences that the first set of theorists allege, and claims about the moral difference between blackmail threats and the acts threatened prove unconvincing.

This Article has originated from a wholly different perspective. Whereas prior theories have proceeded on the express premise, or implicit assumption, that criminalizing particular conduct is justified on one of two competing grounds -either that it yields net adverse social consequences or that it is wrong in itself-this Article has supposed that criminalization of conduct is prima facie justified when it is likely to cause harm and to be undertaken by a morally blameworthy actor. This simple proposition, which might rest on either consequentialist or retributivist conceptions (or both) of the general justifying aim of the institution of criminal punishment, explains why blackmail is criminal even though the acts a blackmailer threatens are not. It is probable that one who simply undertakes an act of the sort a blackmailer might threaten lacks morally bad motives. Therefore, the unconditional act should not be criminal. But more evidence might warrant a different conclusion. In particular, it is probable that one who undertakes the same act, but only after offering to forego the act if paid, acts with bad motives. The threat has evidentiary significance: if the actor had good motives for engaging in the act, he likely would not have offered his abstention. If this inference is sound (and its strength will vary depending upon the totality of circumstances), then this particular act could be made criminal as harm-causing, morally blameworthy conduct. And blackmail-the threat to commit a harm-causing, morally blameworthy act-could be criminalized too.

The two fundamental bases of the evidentiary theory, then, are these: (1) motives matter, and (2) conditional threats can offer powerful (albeit not conclusive) circumstantial evidence of im- 
permissible motive. By employing these two principles, this Article has attempted to resolve one stubborn puzzle of the law. That is, it has sought to explain and to justify the criminalization of "core" cases of blackmail, as well as to suggest a reconsideration of the contours of the crime. Finally, it also has provided some reason for hope that the principles underlying the evidentiary theory might (whether singly or in tandem) have broad explanatory reach both within and without the criminal law. 